\title{
Reactive Transport Modeling of a Historic Waste \\ Rock Pile at the Detour Lake Gold Mine \\ by \\ Phillip Dagenais
}

\author{
A thesis \\ presented to Carleton University \\ in fulfilment of the \\ thesis requirements for the degree of \\ Master of Science \\ in \\ Earth Sciences
}

Ottawa, Ontario, Canada, 2018

(C) Phillip Dagenais 2018 


\section{Author's Declaration}

I hereby declare that I am the sole author of this thesis. This is a true copy of the thesis, including any required final revisions, as accepted by my examiners.

I understand that my thesis may be made electronically available to the public. 


\begin{abstract}
In recent times a lot of emphasis has been placed on environmental sustainability, especially concerning mine waste and management. This includes not only current operations, but those of historic sites as well. Waste rock is one of the largest waste streams produced from mining operations and has often been overlooked in the past. One of the potential byproducts of waste rock is Acid Mine Drainage (AMD), also called Acid Rock Drainage (ARD), from the dissolution of sulfides which can release acidic and metalliferous effluent into the environment. Research is currently ongoing for ways to limit exposure of waste rock to atmospheric conditions.
\end{abstract}

This thesis presents a model of a 1-D, $17 \mathrm{~m}$ high, theoretical waste rock pile with a non-reactive cover that would have existed 30 years in the past at the Detour Lake property. Since short term predictions are difficult due to the heterogeneous nature of waste rock and the seasonal variety from one year to the next, the model simulates 30 years of exposure to atmospheric conditions. The project utilizes hydrological and mineralogical work previously done on site along with 30 years of meteorological data to build the model. Similar procedures may be used to model the long-term generation of AMD on other sites and act a tool to test waste rock management strategies.

The model demonstrates long-term sulfide dissolution consistent with that of the Shrinking Core Model, such as gradual decreases in sulfate and iron production. This is accompanied with a gradual increase in alkalinity and $\mathrm{pH}$ and indicates the carbonate mineral are more than capable of buffering acidity generated from the system. The effluent discharged from the model after 30 years has similar properties to pore water samples collected on-site. Seasonal influxes of water, chiefly melt water and spring rains, had a visible impact on component concentrations. Large infiltrations served as flushing events temporarily increasing concentrations of pore water components and can explain the variety in the sample data collected in the field. Oxygen gas concentrations above $10 \mathrm{~m}$ were higher than averages seen in field observations, however atmospheric levels of oxygen were also observed in this data. These results suggest the non-reactive cover alone is not an adequate measure for limiting the production of AMD. 


\section{Acknowledgments}

I would like to acknowledge those who have helped me throughout this project. First, I would like to acknowledge the help and guidance of my supervisor Dr. Richard Amos who introduced me to the Detour Lake Research Program and presented me with this project. By extension I would also like thank our project partners at University of Waterloo and the University of Alberta.

A special thank you to Aileen Cash from the University of Alberta, and Mark Steinepreis and Brayden McNeill from the University of Waterloo for their contributions. The data collected from their work on the historic waste rock piles was necessary in constructing the model presented in this thesis. I would also like to thank David Wilson from the University of Waterloo for his help with the MIN3P software, and Jeff Bain and Allison Reynolds, also from the University of Waterloo, for their technical expertise and assistance in maintaining the field instruments and collecting field data.

Finally, I would like to thank the Detour Gold Corporation for their on-going collaboration and hospitality. In particular, the Environment Department who helped with logistical support and safety on site. 


\section{Dedication}

I dedicate this work first and foremost to my betrothed whose support has been invaluable through this project. I also dedicate this work to my generation which is tasked with not only solving problems in the present and future, but also those of the past. 


\section{Contents}

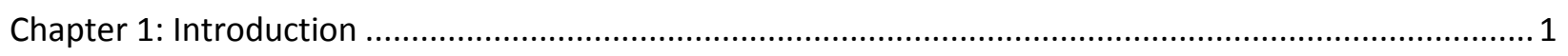

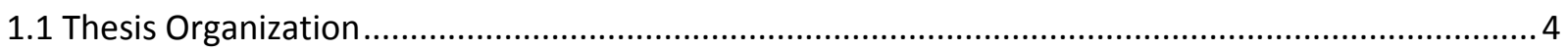

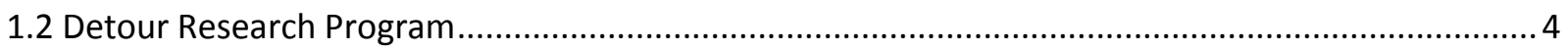

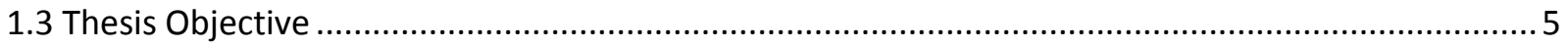

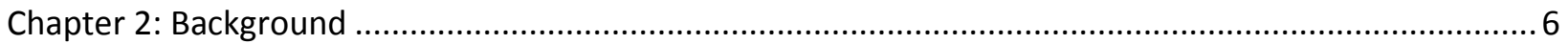

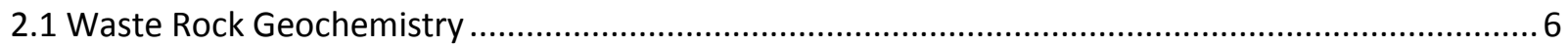

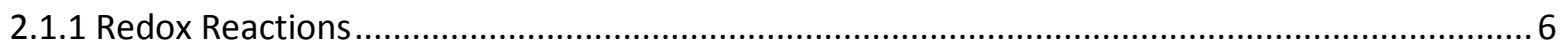

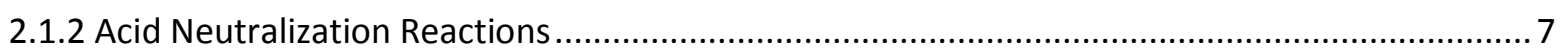

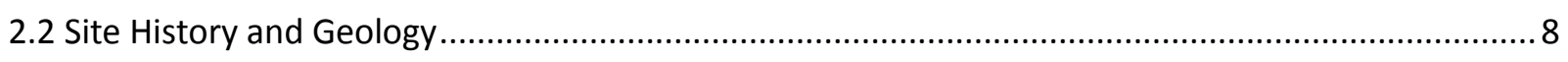

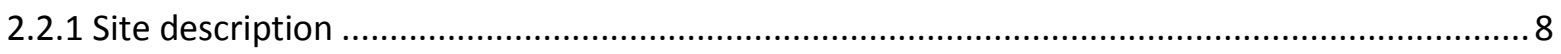

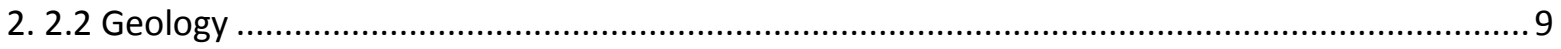

2.3 Historic Waste Rock Pile Characterization ............................................................................. 10

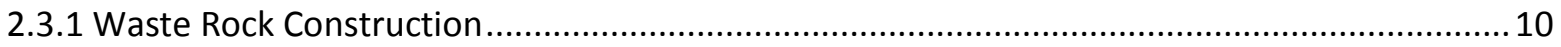

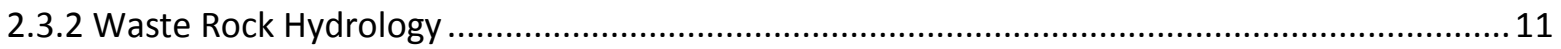

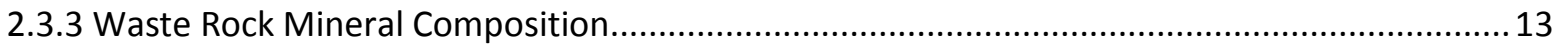

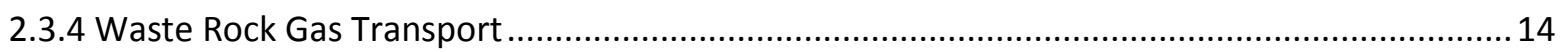

2.3.5 Waste Rock Pore Water Geochemistry.......................................................................... 14

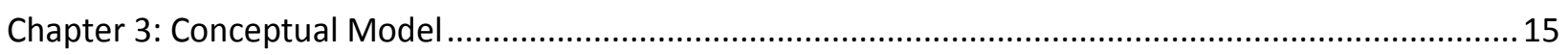

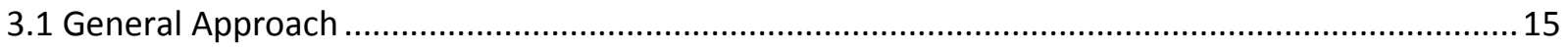

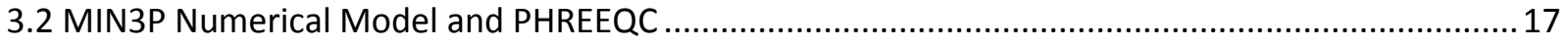

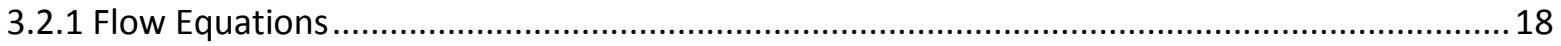

3.2.2 Multicomponent Reactive Transport Equations ................................................................ 18

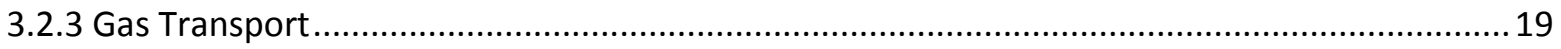

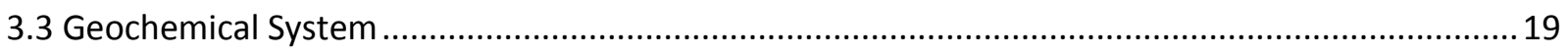

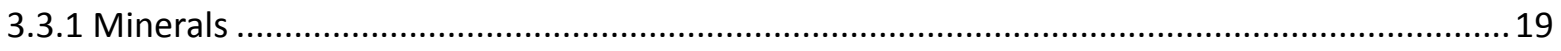

3.3.2 Mineral Precipitation-Dissolution: Surface-Controlled Reactions ...........................................21

3.3.3 Mineral Precipitation-Dissolution: Transport-Controlled Reactions ...................................... 21

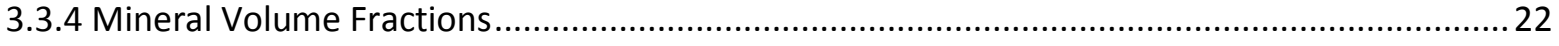

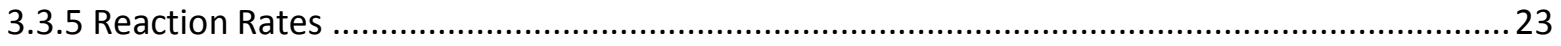

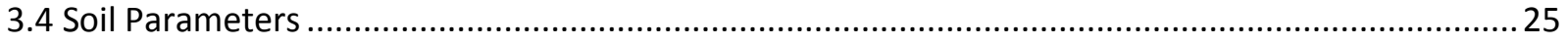

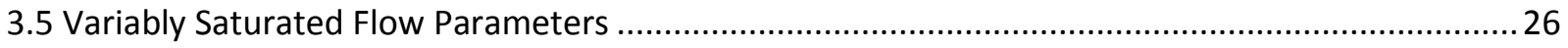

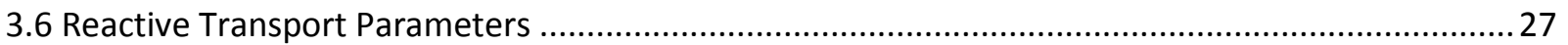




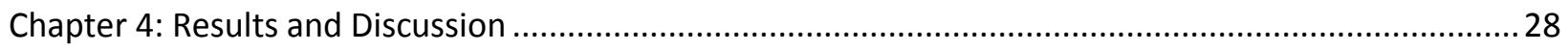

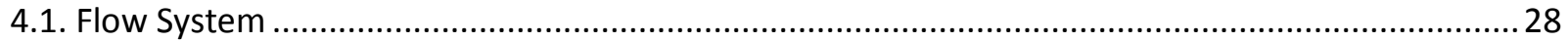

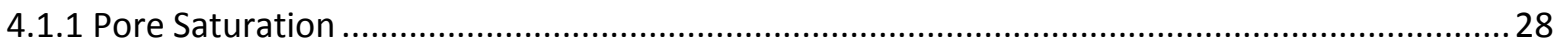

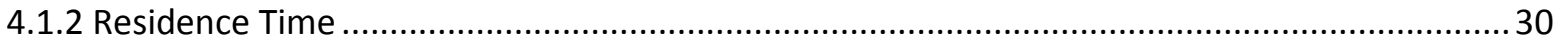

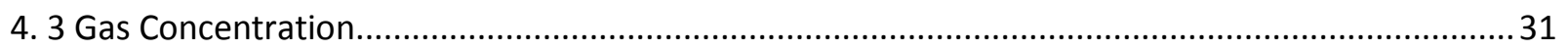

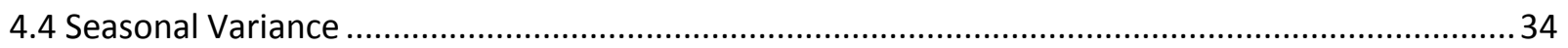

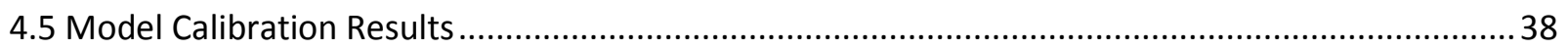

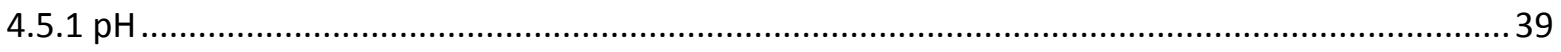

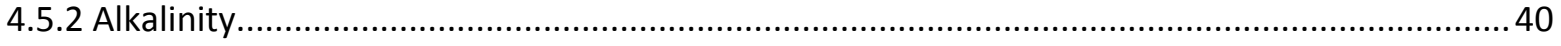

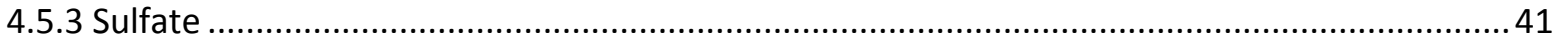

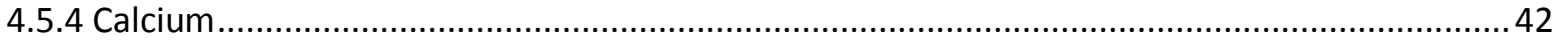

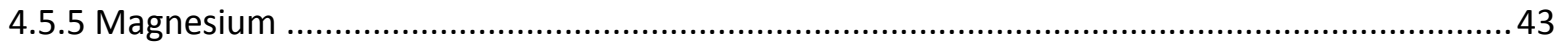

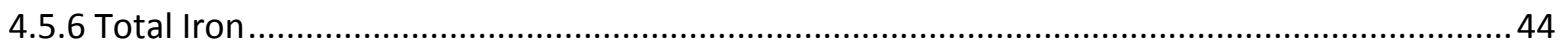

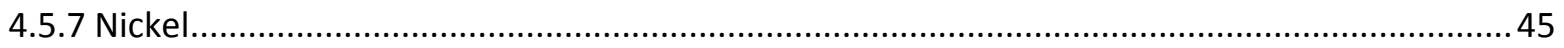

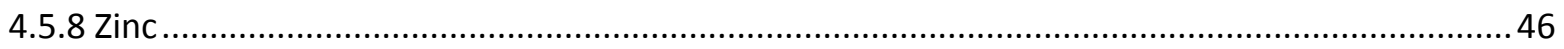

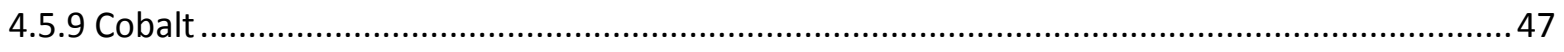

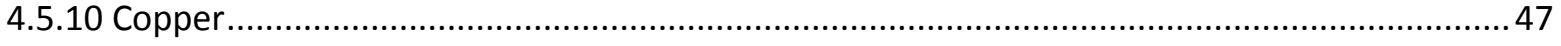

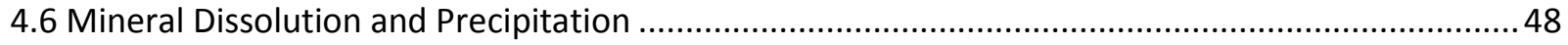

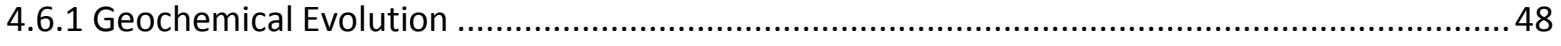

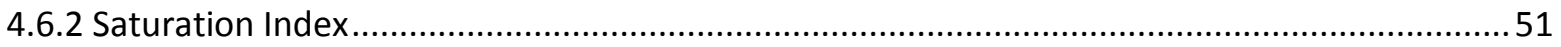

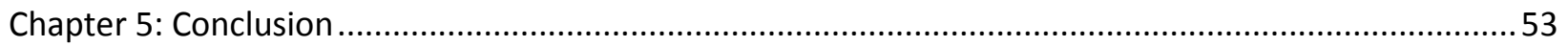

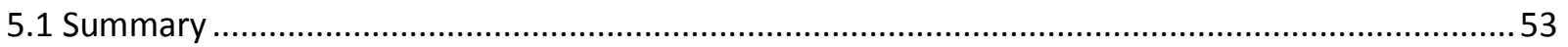

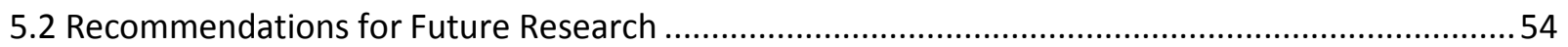

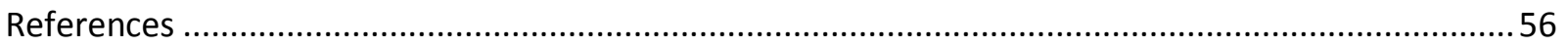

Appendix A: Evapotranspiration, Snow Water Equivalent and Sublimation Calculations.......................... A1

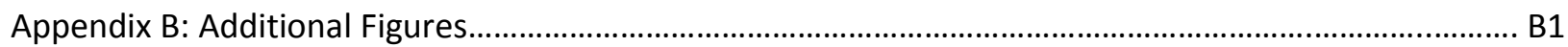




\section{Chapter 1: Introduction}

Since antiquity, human beings have benefited greatly from mining. From the chert mines at Nazlet Sabaha, Egypt, that are dated to as far back as 50000 years ago, to mines in the Chalcolithic age where copper ore was used to make bronze, mining has always been part of humanity (Dionne, 2014; HudsonEdwards et al., 2011). Today we find the products of mining in our cell phones, in the vehicles we drive, building materials etc. As populations have continued to grow and technological advancements have progressed, demand has risen for certain commodities and so too has the scale of mining around the world. This has made the mining industry one of the largest contributors to the global economy. In 2015, the mining industry accounted for $19 \%$ of the total value of exported goods and contributed $\$ 56$ billion to the GDP in Canada. The industry employs 373,000 workers with 190,000 indirectly employed as a result, in addition, the industry will require more than 106,000 skilled workers in the next decade. Those employed by the mining industry enjoy the highest average annual salary out of industrial sectors in Canada, with average earnings exceeding $\$ 115,000$ (The Mining Association of Canada, 2016).

Unfortunately, there is also an environmental cost associated with mining. Many chemicals are often used to process ore such as cyanide used in gold leaching, generating leftover waste once the processing is complete (La Brooy et al., 1994). This processed waste material is known as tailings. Historically more emphasis was placed on impact of tailings on the environment, and most of the remediation/management costs have also gone in reducing this impact. However, tailings are not the only form of waste. Material that is below the cut-off grade to be economically feasible or material necessary for removal to reach ore grade material is known as waste rock (Lottermoser, 2010) and represents an important environmental risk (Coumans, 2003; The Mining Association of Canada, 2016).

This fresh waste rock material becomes exposed to rainwater and the oxygen rich atmosphere, accelerating chemical and physical weathering, and therefore increasing the potential for metalliferous and acid leaching known as Acid Rock Drainage (ARD) or Acid Mine Drainage (AMD) (Moncur et al., 2005). Waste rock is often classified as non-acid generating (NAG) or potentially acid generating (PAG) based on the potential of (primarily) sulfides to oxidize and produce acidity. This classification is used in the management of waste rock and controlling the effects of AMD (Landers et al., 2014).

AMD can have a large environmental impact on ecosystems due to its acidic $\mathrm{pH}$ and dissolved heavy metal content. Acidic $\mathrm{pH}$ and excess metals can disrupt the nutrient uptake of plants and affect the 
physiological functions of aquatic organisms which generally exist in a system with natural $\mathrm{pH}$ between 6-9 (Lenntech, 2018; Simate and Ndlovu, 2014). This leads to less than ideal living conditions and eventual death with increasing acidity, as well as promoting the invasion of non-desirable species. In addition, heavy metals can bio-accumulate in organisms and work their way up the food chain, indirectly affecting animals further removed from the location of the AMD, including humans (Simate and Ndlovu, 2014).

Heavy metals can also directly impact human health due to their toxicity and long-term effects. Heavy metals can accumulate in vital organs and impact their function. Furthermore, they can interfere with absorption of necessary minerals and disrupt the body's ability to make use of these essential minerals (Singh et al., 2011). For example, excess levels of copper (exceeding $0.10 \mathrm{mg} / \mathrm{L}$ ) can lead to anemia, liver and kidney damage, whereas lead concentration exceeding $0.10 \mathrm{mg} / \mathrm{L}$ can result in severe developmental problems in young children and developing fetuses, and cause chronic damage to the nervous system among many other effects (Solomon, 2008; Simate and Ndlovu, 2014).

In terms of scale, in Ontario alone there exists at least 5762 known orphaned and abandoned mines of which several hundred are cause for concern according to the Abandoned Mines Information System (AMIS) database (2018). Databases like these help to supply the National Orphaned and Abandoned Mines Initiative (NOAMI) with information on abandoned and orphaned mines across Canada, of which there are thousands more, not including missing data as seen by the lack of data from British Columbia (Figure 1). 


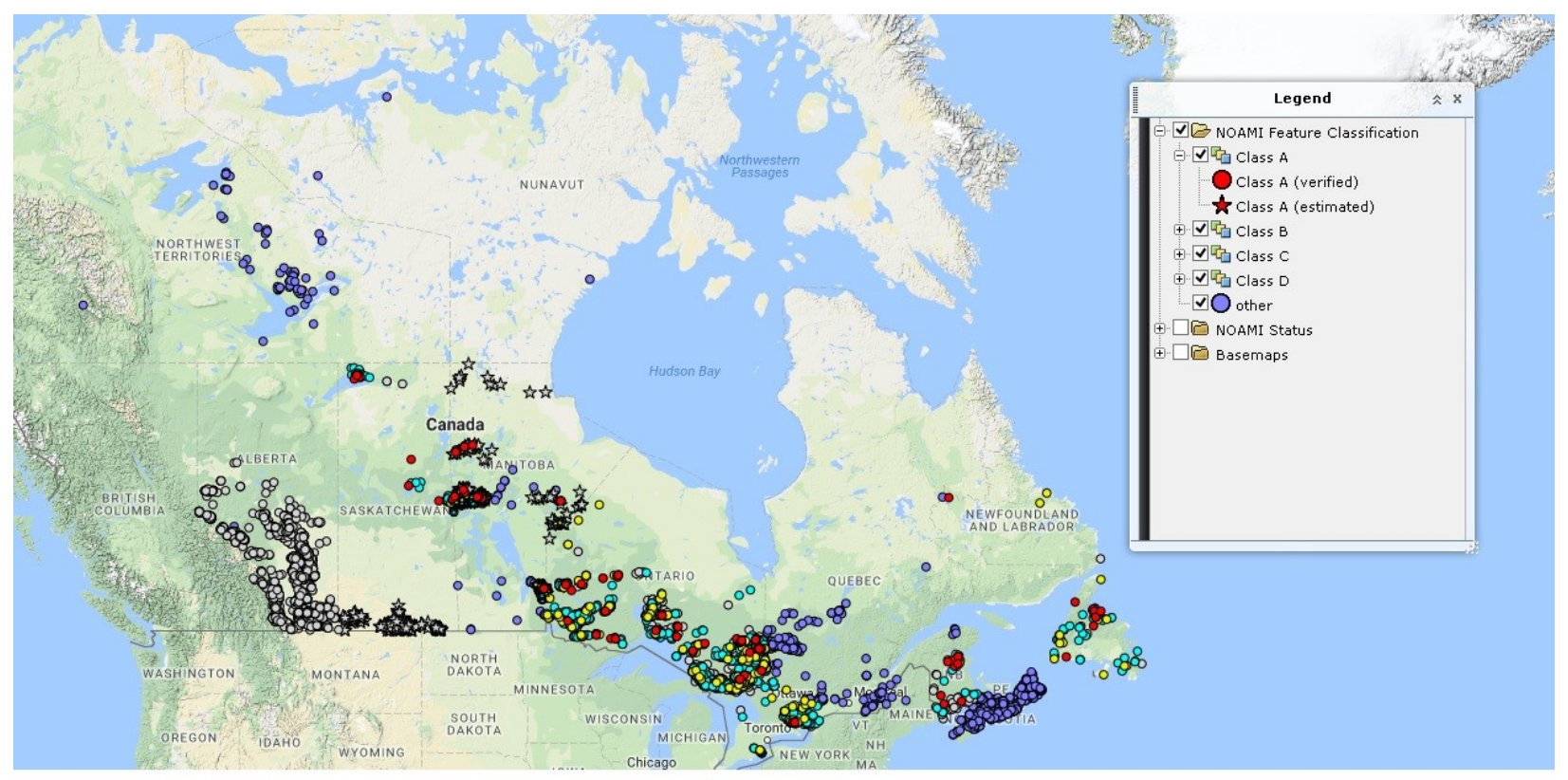

FIGURE 1- LOCATION OF ABANDONED AND ORPHANED MINES ACROSS CANADA (NOAMI, 2018)

Statistics Canada (2012) estimates that the mining industry generates approximately 1 million tonnes of waste rock each day or 365 million tonnes a year, not including historic waste rock piles. Although the life of a typical mine is $15-20$ years, AMD from a waste rock pile may continue to produce effluent for thousands of years (Coumans, 2003).

On a global scale, this represents a significant potential for environmental impact (INAP, 2014). The costs associated in managing AMD on these timescales is not practical. In addition, with the increasing emphasis on environmental impacts this maintenance would not be economically feasible for mining companies (Coumans, 2003; The Mining Association of Canada, 2016). Tremblay and Hogan (2001) estimated costs for total worldwide liability associated with the current and future remediation of AMD to be $\$ 100$ billion. This emphasizes the importance in the understanding and management of current and historic waste rock piles.

A new tool for this characterization is the use of numerical modeling software to test and understand the effluent generated by mine waste and contaminated sites. MIN3P is one such numerical model that can calculate both the hydrological and geochemical systems simultaneously (Mayer et al., 2002). In such instances MIN3P software has been used to characterize solute transport and acid neutralizations reactions in tailings (Brookfield et al., 2006; Jurjovec et al., 2004), nickel sorption processes and release into effluent (Demers et al., 2013), sulfide isotope 
fractionation in contaminated water (Gibson et al., 2010) as well as the effect of different covers placed over tailings to reduce AMD generation (Pabst et al., 2017; Ouangrawa et al., 2009; Molson et al., 2007). Most recently, work by Wilson et al. (2018) simulated the geochemical evolution of waste rock from the Diavik Diamond Mine in humidity cell experiments to characterize the dependence of temperature and sulfide content on AMD generation. Apart from this, most of the work done to date using MIN3P software has not been on waste rock but primarily tailings and other contaminated sites. The complexity of waste rock in addition to variable climate over longer timescales presents a unique problem.

\subsection{Thesis Organization}

This thesis is divided into five chapters. Chapter one serves as an introduction to the thesis and outlines research objectives. Chapter two discusses the waste rock geochemistry, the site background and geology at Detour Lake, and details previous work carried out on site which includes hydrological, geochemical and gas transport characterization. Chapter three introduces the conceptual model and includes a brief on the MIN3P software as well as input parameters for the simulation. Chapter four provides the results and discussion of the MIN3P simulation. Chapter five presents the conclusions of this thesis and provides some possibilities for additional work to be carried out on the historic waste rock piles.

\subsection{Detour Research Program}

The Detour Gold Waste Rock Research Project was started in 2011 by researchers from the University of Waterloo, the University of Alberta and as of 2014, Carleton University. The goal of the project is to characterize four historic waste rock stockpiles (named WRS 1 through 4) from previous mining activities at the Detour Lake Mine which ceased in 1999. The research seeks to understand pore water movement and geochemistry within the waste rock piles in the hopes that the data collected can help with future management of AMD from sulfide-bearing waste rock. Currently there are several monitoring techniques and a host of monitoring equipment in place on WRS 3 and WRS 4 . These include permeability testing, $\mathrm{ECH}_{2} \mathrm{O}$ probes to measure moisture content, tensiometers to measure water tension, thermistors to measure temperature, Soil Water Solution Sampling (SWSS) lysimeters to collect samples from unsaturated waste rock, water sampling wells to collect water from below the water table, and pore gas composition $\left(\mathrm{O}_{2}\right.$ and $\left.\mathrm{CO}_{2}\right)$ sampling ports. In addition, unique to WRS 3 is a data logger connected to pressure sensor probes that measures the internal pressure gradients of WRS 3 in 
relation to wind vector measurements and atmospheric pressure. The project has four overall research objectives:

1. To characterize and understand the hydrology of the existing waste rock stockpiles at the Detour Lake site.

2. To determine the distribution and reactivity of acid-generating sulfide minerals, acid-consuming components, including carbonate minerals, and secondary minerals within the existing wasterock stockpiles at the Detour Lake site and to determine the mechanisms controlling the release, transport and attenuation of acidity and dissolved trace elements.

3. To assess the effect of pile construction and configuration on the rates of gas transport, sulfide mineral oxidation, water transport and water chemistry within waste rock stockpiles.

4. To determine scaling relationships between small-scale laboratory measurements and measurements made on the operational waste rock piles at the Detour Lake site and to evaluate differing scaling approaches.

Objectives 1 and 3 were initially investigated by Cash (2014) with a sampling program aimed at the physical characterization of a waste rock pile which included a survey on grain size distribution using sieve analysis, and Digital Image Processing (DIP) analysis. An analysis of flow was conducted from the results of the sampling program and a theoretical flow model.

A mineralogical analysis of select samples collected by Cash (2014) using X-Ray Florescence (XRF) and electron microscopy (SED-EDS) was carried out by McNeill (2016). Geochemical data gathered from instrumentation installed on WSR piles 3 and 4 was also examined. In addition, bacterial analysis and acid base accounting (ABA) was carried out by McNeill (2016), contributing to Objectives 1 and 2 identified by the Research Program.

Most recently, work by Steinepreis (2017) examining gas transport mechanisms addressed Objectives 2, 3 and 4. Steinepreis (2017) identified advective transport of oxygen is the main source of $\mathrm{O}_{2}$ within the waste rock pile and identified a series of intermediate sulfur species produced as iron sulfides are oxidized to sulfate.

\subsection{Thesis Objective}

The goal of this thesis is to simulate exposure of the historic waste rock pile to 30 years of atmospheric oxygen and rainwater; starting with theoretical fresh waste rock that would have been present when 
the waste rock piles were deposited; and evolving to conditions presently found on WRS 3. A model that is successful in reproducing the geochemical and hydrological characteristics of WRS 3 can then be used to examine the geochemical evolution over time within the waste rock.

Waste rock piles are highly variable and so too are seasonal variations, making short term predictions difficult since a variety of assumptions are needed for model simulation. A longer time frame for simulation allows many of the variations to average out over time, making the assumptions more robust in long term projections of Acid Mine Drainage and metalliferous effluent. This modeling methodology could prove to be invaluable in the management of future waste rock piles (such as those currently under construction at the Detour Gold Mine) by providing a means to predict AMD in a variety of scenarios.

\section{Chapter 2: Background}

\subsection{Waste Rock Geochemistry}

\subsubsection{Redox Reactions}

Oxidizing iron-sulfide minerals are the primary source for AMD in waste rock piles. The oxidation reactions result in the release of $\mathrm{H}+$ ions which lower the $\mathrm{pH}$ of infiltrating rainwater as it drains through the rock pile. In addition to lowering the $\mathrm{pH}$, by-products such as sulfate and metals are also released into the pore water. The primary sulfides identified at the Detour Gold mine are pyrrhotite and pyrite with minor chalcopyrite, and pentlandite (Robertson et al., 2012).

At $\mathrm{pH}$ levels above 4, the oxidation of sulfides is primarily by oxygen. The oxidation reaction for pyrrhotite is as follows (Nicholson and Scharer, 1994; Belzile et al., 2004):

$$
F e_{(1-x)} S+(2-0.5 x) O_{2}+x H_{2} O \Rightarrow(1-x) F e^{2+}+S O_{4}^{2-}+2 x H^{+}
$$

Similarly, the oxidation reaction for pyrite can be described as follows (Blowes et al., 1994):

$$
\mathrm{FeS}_{2}+3.5 \mathrm{O}_{2}+\mathrm{H}_{2} \mathrm{O} \Rightarrow \mathrm{Fe}^{2+}+2 \mathrm{SO}_{4}^{2-}+2 \mathrm{H}^{+}
$$

The by-products of these two reactions are ferrous iron, sulfate and $\mathrm{H}^{+}$ions. Although similar, the chemical structure of pyrrhotite is somewhat deficient in iron leading to a range of chemical formulas and as a result of this structure, it oxidizes more readily in atmospheric conditions. The rate can be up to 
two orders of magnitude greater than pyrite (Nicholson and Scharer, 1994). In low pH (less than 4) conditions, ferrous iron can be oxidized (Belzile et al., 2004);

$\mathrm{Fe}^{2+}+0.25 \mathrm{O}_{2}+\mathrm{H}^{+} \Rightarrow \mathrm{Fe}^{3+}+0.5 \mathrm{H}_{2} \mathrm{O}$

And, at marginally acidic to neutral $\mathrm{pH}$ conditions, most ferric iron is precipitated out as iron oxyhydroxides such as ferrihydrite (equation 4), and therefore does not contribute significantly to the dissolution of iron sulfides (Belzile et al., 2004).

$\mathrm{Fe}^{3+}+3 \mathrm{H}_{2} \mathrm{O} \Rightarrow \mathrm{Fe}(\mathrm{OH})_{3(s)}+3 \mathrm{H}^{+}$

At lower pH levels however, oxidation by ferric iron is more prevalent. This is because in these acidic conditions iron oxyhydroxides are more soluble leading to more ferric iron remaining in solution and allowing oxidation with iron sulfide minerals to occur. Oxidation reactions for pyrrhotite and pyrite, respectively are as follows (Belzile et al., 2004; Blowes et al., 1994):

$F e_{(1-x)} S+(8-2 x) F e^{3+}+4 H_{2} O \Rightarrow(9-3 x) F e^{2+}+S O_{4}^{2-}+8 H^{+}$

$\mathrm{FeS}_{2}+14 \mathrm{Fe}^{3+}+8 \mathrm{H}_{2} \mathrm{O} \Rightarrow 15 \mathrm{Fe}^{2+}+2 \mathrm{SO}_{4}^{2-}+16 \mathrm{H}^{+}$

The ferric iron dissolution pathways for pyrite and pyrrhotite release a significant amount of $\mathrm{H}^{+}$ions leading to a quick decrease in $\mathrm{pH}$. In acidic conditions with adequate levels of oxygen present, the combination of both the oxygen and ferric iron dissolution pathways leads to a much larger production of acid mine drainage.

\subsubsection{Acid Neutralization Reactions}

The oxidation of iron sulfides results in the generation of acidity. This generation of acidity can be buffered by the dissolution of other minerals that consume the excess $\mathrm{H}^{+}$. If the rate of $\mathrm{H}^{+}$consumption exceeds the acidity produced from the weathering and dissolution of sulfides, then the net result is an increase in alkalinity in solution and a greater capacity to buffer $\mathrm{pH}$. (Strömberg and Banwart, 1999). The $\mathrm{pH}$ levels will remain relatively stable until the primary buffering minerals (usually carbonates) are dissolved out. As the volume of the primary buffering minerals is consumed, the alkalinity in solution is reduced and the $\mathrm{pH}$ begins to drop. Next, the drop in $\mathrm{pH}$ will facilitate the dissolution of oxyhydroxides 
such as ferrihydrite, and another series of acid neutralization reactions begin to occur. The process is sequential, and these reactions are well known from the study of tailing impoundments (Blowes et al., 1994; Smyth, 1981; Morin, 1983; Dubrovsky, 1986; Morin et al., 1988). It begins with the initial dissolution of carbonate minerals which buffer the $\mathrm{pH}$ to approximately 6.5-7.5. (Blowes et al., 1994; Strömberg and Banwart, 1999) This reaction is described below for calcite and dolomite; the two principle carbonate minerals found at the Detour Gold mine (Blowes et al., 1994):

Calcite Dissolution

$\mathrm{CaCO}_{3}+\mathrm{H}^{+} \Rightarrow \mathrm{Ca}_{2}^{+}+\mathrm{HCO}_{3}^{-}$

Dolomite Dissolution

$\mathrm{CaMg}\left(\mathrm{CO}_{3}\right)_{2}+2 \mathrm{H}^{+} \Rightarrow \mathrm{Ca}^{2+}+\mathrm{Mg}^{2+}+2 \mathrm{HCO}_{3}^{-}$

Secondary minerals may form from the dissolution of the carbonate minerals such as siderite:

$\mathrm{CaCO}_{3}+\mathrm{Fe}^{2+} \Rightarrow \mathrm{FeCO}_{3(s)}+\mathrm{Ca}^{2+}$

These secondary minerals along with oxyhydroxides will begin to dissolve once the carbonates have been exhausted and will typically buffer the $\mathrm{pH}$ between 4.8 and 6.3. As $\mathrm{pH}$ declines further, this buffering process is followed by the dissolution aluminum hydroxides (such as Gibbsite) that buffer $\mathrm{pH}$ between 4 and 4.3. Once the aluminum hydroxides have been exhausted, iron hydroxides (such as goethite) will begin to dissolve. The $\mathrm{pH}$ levels at this stage are usually below $\mathrm{pH} 3.5$. It is at this point that dissolution of aluminosilicate minerals such as albite and anorthite will begin to occur (Blowes et al., 1994).

\subsection{Site History and Geology}

\subsubsection{Site description}

The Detour Lake property encompasses an area of $625 \mathrm{~km}^{2}$ in northeast Ontario, Canada.

Geographically, the mine site is approximately $14.3 \mathrm{~km}$ from the Quebec border and $128 \mathrm{~km}$ south of James Bay. By vehicle, the site is $185 \mathrm{~km}$ northeast of Cochrane, Ontario, via an extension to highway 652 north. Climate data for the site is estimated from Environment Canada meteorological stations at Kapuskasing, Ontario, and Matagami, Quebec. Average temperatures range from $16.6^{\circ} \mathrm{C}$ in July to -18.8 ${ }^{\circ} \mathrm{C}$ in January with a mean temperature of $0.3^{\circ} \mathrm{C}$, with average total precipitation estimated at $851 \mathrm{~mm}$ annually. 
The site was initially discovered by Amoco Canada Petroleum Company Ltd. in 1974 using airborne geophysical surveys. Amoco began an exploration project in 1975 comprised of 47,444 meters of surface drilling, confirming the presence of a large gold deposit. This was followed by an extensive exploration program by Campbell Red Lake Mines from 1979-1982 (DGC, 2016).

Open pit mining began in 1982. In 1987 Campbell Red Lake Mines merged with Dome Mines Ltd. and Placer Development to become Placer Dome Inc. Mining underground commenced and continued along with open pit mining until 1999 when mining ceased. Production was approximately 1.8 million ounces of gold from 14.3 Mt of rock over the 17-year period (DGC, 2016).

On January $11^{\text {th }}, 2013$, Detour Gold resumed mining activities on the property, with full scale commercial production occurring in August, 2013. This saw a significant expansion of the open pit with plans for expansion to the west known as West Detour (DGC, 2016). The total inferred resources are estimated at 44.9 million tonnes at $0.82 \mathrm{~g} / \mathrm{t} \mathrm{Au}$, with a cut-off grade of 0.5 for a total inferred amount of $1,188,000$ gold ounces. The reserves for the entire Detour Lake property are estimated to be 508 million tonnes at $0.97 \mathrm{~g} / \mathrm{t} \mathrm{Au}$, for a total of 15,814,000 gold ounces (DGC, 2017).

\section{2.2 Geology}

The Detour Lake property is situated within the northwestern portion of the Abitibi Greenstone Belt of the Superior Province of the Canadian Shield. The Abitibi Greenstone Belt is world renowned as a rich mining area with reserves of gold, copper, zinc and silver and is host to several volcanogenic massive sulfides (VMS) deposits and epigenetic gold deposits with a total mineral production valued at approximately $\$ 120$ billion as of 2005 (DGC, 2016; Oliver et al., 2012). The Detour Lake area has undergone higher levels of metamorphism in contrast to the more southern portion of the Abitibi Greenstone Belt and is characterized primarily by a biotite-actinolite-albite-pyrrhotite assemblage associated with this higher-grade metamorphism (amphibolite facies) (Oliver et al., 2012). Although pyrrhotite is the main sulfide, pyrite is present, with lesser chalcopyrite and with minor pentlandite and arsenopyrite. The primary carbonates are calcite and lesser dolomite (Robertson et al., 2012).

The primary gold deposit is found on the contact between younger (2.70 Ga) Caopatina Assemblage sedimentary rocks overlain by mafic to ultramafic rocks of the $(2.72 \mathrm{Ga})$ Deloro Assemblage. The Caopatina formation is characterized by volcaniclastic sediments, quartz wackes, laminated argillites, and some tuffaceous rocks. The Deloro Group Assemblage is made up of two formations, the Upper 
Detour Lake Formation (UDLF) and the Lower Detour Lake Formation (LDLF). The Upper Detour Formation is made up of mafic tuffs, mafic flows, mafic hyaloclastites and pillow flows. In contrast, the Lower Detour Lake Formation is made up of ultramafic to mafic flows, sills and dikes, a cherty layer named the Chert Marker Horizon (believed to be a deformed felsic volcaniclastic unit), and felsic volcaniclastic rocks. Mineralization at the Detour Lake property is situated within a regional thrust fault known as the Sunday Lake Deformation Zone between the Deloro and Caopatina Assemblages. Most of the auriferous mineralization is found on the northern hanging wall (Deloro Group) portion of the fault between the Upper Detour Lake Formation and Lower Detour Lake Formation, primarily in the Chert Marker Horizon and a network of quartz carbonate vein stockwork that move off from the main deformation zone. The veining likely formed after the thrust-related deformation, under a strike-slip transpression event (Oliver et al., 2012).

\subsection{Historic Waste Rock Pile Characterization}

\subsubsection{Waste Rock Construction}

Mining companies typically store waste rock in close proximity to the mine. Pile construction varies but there are two primary methods used, end-dumping and push-paddock dumping. End dumping is the process in which waste rock is carried to the edge of a waste rock pile and dumped. When the outer edges of the pile have reached their limits, the waste rock is piled higher. Bulldozing may be required to create a nicer surface for the dump trucks to travel on. Push-paddock dumping is the process in which several consecutive dump sites are deposited in succession before the waste rock is bulldozed over the edge of the pile. Regardless of which process is used, as traffic moves over the surface a compacted layer is formed known as a traffic surface. Throughout the construction process as waste rock is piled higher, there may be several traffic surfaces formed. The waste rock between each traffic surface succession is known as a lift.

Through the deconstruction process of a historic waste rock pile at the Golden Sunlight Mine in southwest Montana, USA, Herasymuik (1996) found that the end dumping process often used to construct rock piles causes segregation of rock clasts primarily due to gravity and clast size distribution can be highly variable. During the dumping process, the smaller clasts tend to be deposited near the dump site. Larger clasts will typically roll down the slope and settle at the base of the pile forming a coarse base. Continued dumping will form a series of layers varying in thickness from dozens of centimeters to several meters, dipping at the same angle as that of the slope of the pile and a 
compacted layer or traffic surface created by the process. As multiple layers of waste rock are piled on to each other, this will lead to a heterogeneous and highly structured waste rock pile.

At Detour, Cash (2014) determined that the stockpiles showed some evidence for end dumping type construction, but the primary method was most likely push-paddock type dumping with 10-15m lifts. The lifts were separated by compacted material believed to be traffic surfaces. The result was material segregation with coarser material at the base and dipping beds. These findings are consistent with Herasymuik (1996) suggesting that although the processes differ, dipping beds with material segregation due to gravity separated by traffic surfaces is common to both types of dumping.

\subsubsection{Waste Rock Hydrology}

In unsaturated conditions, flow in waste rock is dependent on grain size and pore space and is characteristic of a material. A Soil Water Characteristic Curve (SWCC) which relates matric suction to water content can be a valuable tool to determine material properties, where matric suction is simply the difference between the air pressure $U a$ and water pressure $U w$ and is related to the pressure head (also called total suction) by the equation $\Psi=(U a-U w)+\pi$, where $\pi$ is osmotic suction. (Fredlund and Xing, 1994; Fredlund et al., 2012). This is especially true for finer grain sizes. Water between the grains is held under tension and is proportional to the curvature of the meniscus formed from the water connection between grains (Figure 2).

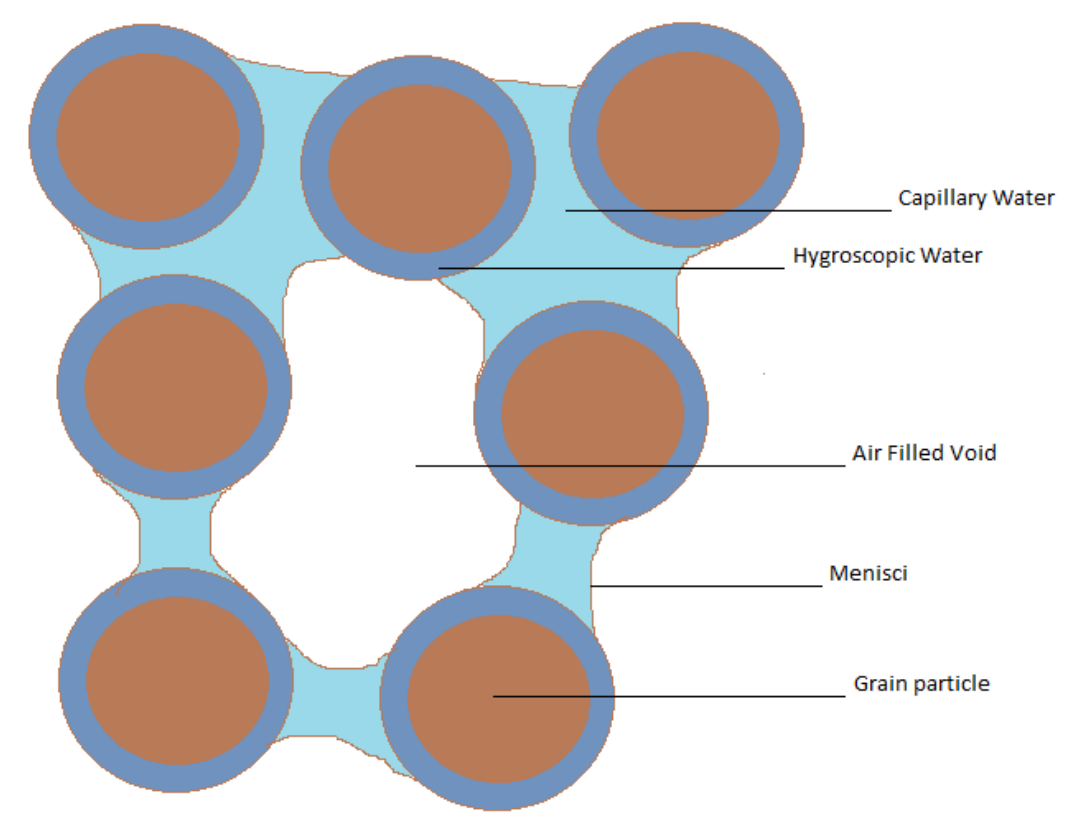

FIGURE 2 - CAPILLARY WATER AND MENISCI BETWEEN FINE GRAINED PARTICLES 
The water held by this water tension is known as capillary water. When water content decreases, the radius of the meniscus decreases, increasing the tension between the water and the grains. This process can lead to capillary flow, controlled by differences in matric suction. Particles that are larger with greater distances (pore space) between them are not able to retain water under the increased matric suction experienced in drier conditions and are unlikely to have capillary flow. (Dingman, 2002; Fredlund et al., 2012).

Herasymuik (1996) demonstrated that waste rock can be generally categorized into two different rock material types. Type one materials are physically defined as finer grained having more than $40 \%$ passing through a $4.75 \mathrm{~mm}$ sieve. They can retain water in unsaturated conditions, retain higher unsaturated hydraulic conductivities and the behavior of their SWCC is dominated by finer material. Type two materials have fewer than $40 \%$ clasts passing the $4.75 \mathrm{~mm}$ sieve. They typically drain very quickly under small values of matric suction, have a rapidly decreasing hydraulic conductivity and have little capacity to retain water under unsaturated conditions. Similarly, Stockwell et al., (2006) found that although subsurface flow is difficult to characterize, flow within a stockpile at Key Lake, Saskatchewan, demonstrated preferential flow through coarser material during wet conditions, and flow through finer material (capillary flow) in drier conditions. At the Detour Gold mine site, 4 historic waste rock piles, named waste rock stockpile (WRS) 1 through 4, were deposited during the initial mining activities which ceased in 1999 and were left exposed to the elements. Cash (2014) carried out a similar geotechnical and hydrological analysis on WRS 1 and 2. Relocation of these two stockpiles was necessary as they were within the planned footprint of the open pit. This provided an opportunity for in-situ test pit and full-scale excavation sampling.

Physical observations by Cash (2014) provided an insight into the heterogeneous nature of the historic Detour waste rock. The piles were found to include a cover of $0.3-1 \mathrm{~m}$ thick glacial overburden that was mainly silty-sand with some larger (up to $0.3 \mathrm{~m}$ diameter) clasts. The waste rock grain sizes ranged from clay sized to $2 \mathrm{~m}$ boulders.

Measurements for matric suction and moisture content were carried out in test pits and pail samples. Matric suction ranged from 1-53 $\mathrm{kPa}$ and moisture content ranged from 0.3-12.5 wt\%. Sieve analysis was conducted on particles up to $75 \mathrm{~mm}$ in size to characterize the fine fraction of the material. Matrix fines were categorized as material that passes the $4.75 \mathrm{~mm}$ sieve. Less than $40 \%$ of material passed 
through the $4.75 \mathrm{~mm}$ sieve indicating the waste rock can be categorized as primarily rock-like. Digital image processing (DIP) was conducted to characterize the larger particles, indicating the fraction of matrix fines within the totality of the waste rock material is only approximately $17 \%$.

Soil water characteristic curves constructed from this data indicated quick drainage under low matric suctions for the larger waste rock particle fraction, and that the flow is controlled by the matrix fines fraction of the waste rock pile material. These findings mirror the flow results of Herasymuik (1996) and Stockwell et al., (2006) characterizing flow within waste rock material and the tracer test results of Nichol et al., (2005) where waste rock below the wetting front carried less than $0.1 \%$ of net infiltration in non-capillary flow. Furthermore, work carried out on large test piles at the Diavik Diamond mine located in the Northwest Territories also showed that matrix flow is the dominant mechanism, even though only $18 \%$ of waste rock material at Diavik is smaller than $5 \mathrm{~mm}$. (Momeyer, 2003; Neuner et al., 2013; Fretz, 2013)

\subsubsection{Waste Rock Mineral Composition}

Whole rock analysis completed by McNeill (2016) using X-Ray Florescence (XRF) on previously sieved materials from Cash (2014) characterized the weight percentage breakdown of oxides $\left(\mathrm{Al}_{2} \mathrm{O}_{3}\right.$, $\left.\mathrm{CaO}, \mathrm{Fe}_{2} \mathrm{O}_{3}, \mathrm{~K} 2 \mathrm{O}, \mathrm{MgO}, \mathrm{MnO}, \mathrm{Na}_{2} \mathrm{O}\right)$ and the concentration of metals $(\mathrm{Cr}, \mathrm{Cu}, \mathrm{Ni}, \mathrm{Zn}, \mathrm{Pb})$ in their respective sieve fractions. A more detailed analysis of a sample using electron microscopy with energy dispersive spectroscopy (SED-EDS) was done to determine the mineral assemblage. The primary minerals were found to be anorthite and hornblende with weight percentages of $26 \%$ and $20 \%$, respectively, followed by clinochlore at $15 \%$, albite at $12 \%$, quartz at $13 \%$, and vermiculite at $11 \%$.

Testing for total carbon and total sulfur contents using a carbon/sulfur analyzer was done on all the samples yielding ranges of 0 to $2.5 \mathrm{wt} \%$ carbon and 0 to $2.2 \mathrm{wt} \%$ sulfur. These results were used in an Acid Base Accounting (ABA) which concluded that $50 \%$ of samples from WRS 1 and 2 were potentially acid generating (PAG), WRS 4 had $45 \%$ of samples that were PAG, and WRS 3 had no samples that were PAG (McNeill, 2016).

For use in model simulations, average weight percentages for significant sulfides were calculated based on the trace metal concentrations and whole rock analysis done by McNeill (2016). Primary sulfides were pyrrhotite and pyrite with averages of $0.799 \mathrm{wt} \%$ and $0.343 \mathrm{wt} \%$, respectively, with lesser 
chalcopyrite, covellite and pentlandite with $0.037 \mathrm{wt} \%, 0.016 \mathrm{wt} \%$, and $0.025 \mathrm{wt} \%$, respectively, and minor sphalerite and arsenopyrite with $0.008 \mathrm{wt} \%$ and $0.007 \mathrm{wt} \%$, respectively.

\subsubsection{Waste Rock Gas Transport}

On WRS 3, the pore gas analysis of $\mathrm{O}_{2}$ and $\mathrm{CO}_{2}$ showed significant variation. Oxygen levels fluctuated from atmospheric to $0.5 \%$ while carbon dioxide values varied from below detection limit to $15 \%$. The trend of average values demonstrated a decrease of oxygen and increase in $\mathrm{CO}_{2}$ gradually with depth until approximately 15-17 m. At this depth, interaction with the water table may be causing elevated $\mathrm{CO}_{2}$ levels. The air permeability of the $0.5-1.2 \mathrm{~m}$ cover soil was low (at $3 \times 10^{-11} \mathrm{~m}^{2}$ ), approximately 2 orders of magnitude lower than that of the rest of the waste rock at $\left(9 \times 10^{-9}\right.$ to $\left.1 \times 10^{-10} \mathrm{~m}^{2}\right)$. The findings indicate that on WRS 3, the cover material is reducing the influx of atmospheric oxygen (McNeill, 2016).

Steinepreis (2017) setup a network of samplers to measure gas pressure 12 sampling points within WRS 3 with varying depths ranging from $1.7 \mathrm{~m}$ to $15 \mathrm{~m}$, and 12 additional locations around the exterior of WRS3 to record exterior air pressure. Pressure sensors were wired into a data-logger and collected pressure and wind vector measurements every 4 seconds averaged out to 1-minute intervals. Also collected were atmospheric oxygen and carbon dioxide readings at approximately daily intervals. The findings indicated that there was a strong correlation between $\mathrm{O}_{2}$ levels within the rock pile with wind vector and temperature changes; while barometric pressure changes had minimal effect on $\mathrm{O}_{2}$ levels. This indicated that advective transport of $\mathrm{O}_{2}$ was the primary source of atmospheric oxygen into the waste rock (Steinepreis, 2017). WRS 4 pore gas analysis shows atmospheric levels of $\mathrm{O}_{2}$ and $\mathrm{CO}_{2}$ throughout. This was due to a previous excavation on the western side of the waste rock pile, rendering the cover ineffective at preventing the influx of oxygen (McNeill, 2016).

\subsubsection{Waste Rock Pore Water Geochemistry}

Data from 2012-2014 recovered from the in-situ instrumentation in place at WRS 3 and 4 were analyzed by McNeill (2016). Pore water sampling for various depths was limited to two locations on WRS 3, site 3-1 and 3-2. At each of these two sites sampling was limited to 3 depth intervals; $4.2 \mathrm{~m}, 9.2$ $\mathrm{m}$ and $14.2 \mathrm{~m}$ for site 3-1, and $5 \mathrm{~m}, 10 \mathrm{~m}$ and $15 \mathrm{~m}$ for site 3-2, respectively. Sampling times varied year to year based on the availability of the sampling team and the opportunity for site access. Sampling occurred most often from May to September. Due to the sporadic sampling intervals coupled with long- 
term and short-term seasonal variations, and the relatively short time span of the research program, it was difficult to ascertain strong geochemical trends.

The $\mathrm{pH}$ values obtained from the pore water samples are noticeably more neutral with an average pH of 7.9 than the paste pH of samples taken by Cash (2014) from WRS 1 and WRS 2 (pH of 5.76), and rarely dropped below $\mathrm{pH}$ of 7 with the lowest value at $\mathrm{pH}$ 6.96. Although the $\mathrm{pH}$ is typically neutral, the sulfate levels range from 200 to $>2000 \mathrm{mg} / \mathrm{L}$ and are accompanied by trace metals (notably $\mathrm{Co}^{2+}, \mathrm{Ni}^{2+}, \mathrm{Cu}^{2+}$ and $\mathrm{Zn}^{2+}$ ) and levels reaching $370 \mathrm{mg} / \mathrm{L}$ for $\mathrm{Mg}^{2+}$ and $121 \mathrm{mg} / \mathrm{L}$ total iron, indicating sulfide oxidation is taking place and neutral mine drainage is being produced. Alkalinity levels on WRS 3 averaged from 531 to $1000 \mathrm{mg} / \mathrm{LCaCO}_{3}$. The elevated alkalinity indicates a larger capacity for buffering acidity remains. Alkalinity was lower on WRS 4 averaging from $15 \mathrm{mg} / \mathrm{L}$ to 150 $\mathrm{mg} / \mathrm{LCaCO}_{3}$, except for a spike at $25 \mathrm{~m}$ depth from an average of $330 \mathrm{mg} / \mathrm{L}$ to $622 \mathrm{mg} / \mathrm{L} \mathrm{CaCO}_{3}$.

\section{Chapter 3: Conceptual Model}

\subsection{General Approach}

The model was conceived to simulate conditions presently found in WRS \#3 and examine the evolution of waste rock geochemistry over time. Simulating pore water flow and geochemistry through waste rock piles has been proven difficult due to the heterogeneous nature of the waste rock and seasonal variations which include temperature, precipitation etc. However, using various data collected from the Detour Research Program to characterize the waste rock pile's physical and hydrological characteristics, it may be possible to average out the discrepancies over time. The goal of the simulation is to show this and provide a methodology for this process in the hopes it can be used to describe acid mine drainage in other settings. The results simulated using MIN3P software will be compared to pore water samples collected in recent years. In addition, PHREEQC software will be used to compare the saturation indices of the simulated data and the measured pore water samples.

The simulated 1-D column was set as $1 \mathrm{~m} \times 1 \mathrm{~m} \times 17 \mathrm{~m}$ high with the $17 \mathrm{~m}$ length divided into 356 control volumes each representing an interval of approximately $4.8 \mathrm{~cm}$ of waste rock. The top $1.12 \mathrm{~m}$ of the column represented the cover material and the remaining $15.88 \mathrm{~m}$ represented waste rock. The water table was set at $16 \mathrm{~m}$ in depth to mimic measured values in the field (Steinepreis, 2017). Seasonal climate data was taken from the weather station at Kapuskasing, Ontario. The temperature within the waste rock pile was set at $8^{\circ} \mathrm{C}$ as this was the average value observed from $\mathrm{ECH}_{2} \mathrm{O}$ probes within WRS 
3 (McNeill, 2016). Gases considered in the simulation were limited to $\mathrm{CO}_{2}$ and $\mathrm{O}_{2}$. The physical characteristics of the theoretical pile were derived from data collected by Cash (2014) for WRS 1 and 2 and calibrated to match the monitoring data installed on WRS 3. The general mineral assemblage of the theoretical waste rock was estimated from previous work completed by McNeill (2016) on samples from WRS 1 and 2 and geological information from Olivier et al., (2012) and Robertson et al., (2012). Mineral weight percentages were then calculated and converted into bulk mineral volumes for use in MIN3P. Flow through the pile was considered as transient and occurring in a variably saturated medium to mimic seasonal variations. Rainwater enters from the top of the experimental column through infiltration with rates determined from monthly averages. Water exits the bottom of the column freely at the water table. Although under larger rainfall events flow is generally through larger voids and pore space, the residence time is short as the water drains quickly from this material, resulting in little interaction with minerals to occur. This fast, preferential flow does not significantly contribute to AMD or elevated metal levels (Strömberg and Banwart, 1999). For this reason, flow in the conceptual model was limited to flow through the matrix fines. Infiltration of water was only considered for non-winter months since pore water is generally frozen near the surface, preventing further influx of water (Herasymuik, 1996; Stockwell et al., 2006; Nichol et al., 2005; Momeyer, 2003; Neuner et al., 2013; Fretz, 2013; Gray et al., 2001).

The dissolution of the iron sulfides is described using the Shrinking Core Model. The Shrinking Core Model (SCM) approximates the dissolution of a spherical particle and considers a reduction in the reaction rate over time as the particle reacts out. The initial particle is composed of a stagnant water film surrounding an unreacted core. As the surface of the unreacted core begins to react, the portion of the unreacted core begins to shrink, leaving behind reacted material known as either a leached layer or a reaction rim. The reacted material left over from the dissolution reaction acts as a barrier, reducing the influx of oxygen or ferric iron reaching the unreacted core, further reducing the reaction rate. The reaction rate is therefore dependent both on the surface area of the mineral available for reaction, and the diffusion rate of either oxygen or ferric iron across the leached layer as shown in Figure 3 (Yagi and Kunii, 1955; Levenspiel, 1972; Wunderly et al., 1996; Mayer et al., 2002). 

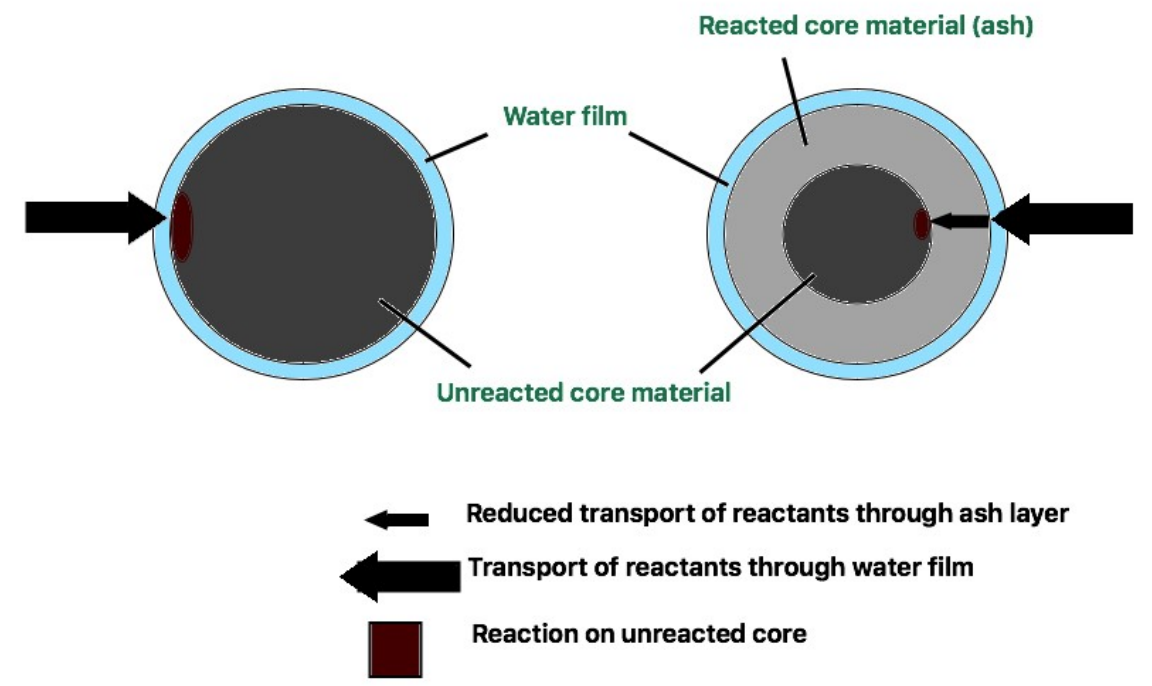

FIGURE 3- THE SHRINKING CORE MODEL (MODIFIED FROM MAYER ET AL., 2002)

\subsection{MIN3P Numerical Model and PHREEQC}

MIN3P is a numerical model used for multi-component reactive transport in variably saturated porous media in one, two or three dimensions. The software can be used to simulate both constant and transient flow and diffusive gas transport in addition to geochemical reactions which include kinetic or equilibrium-controlled reactions, and sulfide mineral dissolution reactions consistent with the Shrinking Core Model. Another one of the benefits of this software is its use of external databases, primarily derived from MINTEQA2 by Allison et al. (1991), for mineralogical and geochemical properties saving a user a lot of time when creating input files.

The software considers solute and gas transport in a three-phase system. It utilizes a globally implicit method which solves reaction and transport processes concurrently, enforcing a global mass balance between the solid phase, aqueous phase and gas phase (Mayer et al., 2015). The simulated domain is divided into a series of control volumes which are linearized for both flow and transport equations using Newton's Method (Mayer et al., 2002; Pabst et al., 2017). For simplicity, fluid is assumed to be incompressible, the air phase is considered passive, and there is no hysteresis (Mayer et al., 2002; 
Neuman, 1973; and Panday et al., 1993). The mass conservation equations for flow and transport are briefly described below.

PHREEQC is as a general-purpose geochemical model. It allows the modelling of reactions in solution, and the reactions between a solution and either sediments or rock. Specific to its use in this project, PHREEQC using the MINTEQ.V4 database was used to model mineral saturation indices of measured pore water samples collected in the field.

\subsubsection{Flow Equations}

MIN3P uses the Richards' equation (Richards, 1931) to describe flow through variably saturated soils.

The mass conservation equation for the relationship between the change in hydraulic conductivity and saturation over time is as follows (Mayer, 1999):

$$
S_{a} S_{s} \frac{\partial h}{\partial t}+\phi \frac{\partial S_{a}}{\partial t}-\nabla \cdot\left(k_{r a_{w}} \bar{k} \nabla h\right)-Q_{a}=0
$$

where $t$ is time (s), $\phi$ is porosity, $S_{a}$ is the water saturation, $S_{s}$ is the specific storage coefficient, $\bar{k}$ is the hydraulic conductivity tensor $(\mathrm{m} / \mathrm{s})$, and $Q_{a}$ is a source-sink term $\left(\mathrm{s}^{-1}\right)$. The relationships between $S_{a}$, the relative permeability, $k_{r a}$, and aqueous phase pressure head (suction pressure) $\psi_{a}=h-z$ can be described by soil hydraulic functions (Wösten and van Genuchten, 1988):

$$
\begin{aligned}
& S_{a}=S_{r a}+\frac{1-S_{r a}}{\left(1+\alpha \psi_{a}^{n}\right)^{m}} \\
& k_{r a}=S_{e a}^{l}\left[1-\left(1-S_{e a}^{1 / m}\right)^{m}\right]^{2}
\end{aligned}
$$

where $S_{r a}$ is the residual saturation (of the aqueous phase), and $l, \alpha, n, m$ (where $m=1-1 / n$ ) are van Genuchten (V.G) hydraulic function parameters for a soil. $S_{e a}$ is the effective saturation for the aqueous phase with values between 1 (fully saturated) and 0 (completely dry) and is defined by:

$$
S_{e a}=\frac{S_{a}-S_{r a}}{1-S_{r a}}
$$

\subsubsection{Multicomponent Reactive Transport Equations}

The mass conservation equations for reactive-transport reactions can be expressed for individual aqueous species (components) (Yeh and Tripathi, 1989; Steefel and Lasaga, 1994; Lichtner, 1996). The 
mass conservation equation for a component is described in terms of total component concentration and is described below (Mayer et al., 2002):

$$
\begin{aligned}
& \frac{\partial}{\partial t}\left[S_{a} \phi T_{j}^{a}\right]+\frac{\partial}{\partial t}\left[S_{g} \phi T_{j}^{g}\right]+\nabla \times\left[q_{a} T_{j}^{a}\right]-\nabla \times\left[S_{a} \phi D_{a} \nabla T_{j}^{a}\right]-\nabla \times\left[S_{g} \phi D_{g} T_{j}^{g}\right] \\
& -Q_{j}^{a, a}-Q_{j}^{a, s}-Q_{j}^{a, e x t}-Q_{j}^{g, e x t}=0 \\
& j=1, N c,
\end{aligned}
$$

where $S_{g}$ is the gaseous phase saturation, $T_{j}^{a}$ and $T_{j}^{g}$ are the total aqueous and gas phase concentrations of component $j, q_{a}$ is the Darcy fluid flux, and $D_{a}$ and $D_{g}$ are dispersion tensors for the aqueous and gas phases. Contributions to $T_{j}^{a}$ from intra-aqueous and precipitation-dissolution reactions are represented by source-sink terms $Q_{j}^{a, a}$ and $Q_{j}^{a, s}$, whereas $Q_{j}^{a, \text { ext }}, Q_{j}^{g, \text { ext }}$ represent external source-sinks for aqueous and gas phases. The gas phase saturation is simply (from Mayer et al., 2002):

$$
S_{g}=1-S_{a}
$$

Solving for the Richard's equation produces the Darcy flux vector, $q_{a}$ (from Mayer et al., 2002):

$$
q_{a}=k_{r a} \frac{\rho_{a} g}{\mu_{a}} k \nabla h
$$

where, $\rho_{a}$ is the aqueous phase density $\left(\mathrm{kg} / \mathrm{m}^{3}\right), g$ is gravity $\left(\mathrm{m} / \mathrm{s}^{2}\right), \mu_{a}$ is the aqueous phase viscosity, $h$ is the hydraulic head $(m)$, and $k$ is the permeability tensor $\left(m^{2}\right)$.

\subsubsection{Gas Transport}

Transport of pore gas in MIN3P is described using a Fickian diffusion process (Thorstenson and Pollock, 1989). MIN3P determines the effective diffusion coefficient according to Aachib et al. (2004) written as:

$D_{p}=\frac{1}{\phi^{2}}\left(D_{p}^{o} \cdot \theta_{p}^{3.4}\right)$

where $p$ is the phase, $D_{p}^{o}$ is the oxygen diffusion coefficient in air $\left(\mathrm{m}^{2} \mathrm{~s}^{-1}\right)$ and $\theta_{p}$ is the porosity filled by phase $p$ (which includes the volumetric water and air content.

\subsection{Geochemical System}

\subsubsection{Minerals}

The generation of AMD is attributed primarily to pyrrhotite and pyrite in the model since the bulk volume compositions are an order of magnitude higher than that of chalcopyrite and two orders of 
magnitude higher than that of sphalerite and pentlandite (Table 1). Chalcopyrite, sphalerite, and pentlandite were included because of the trace metals associated with these minerals found in the pore water geochemistry, mainly $\mathrm{Co}^{2+}, \mathrm{Ni}^{2+}, \mathrm{Cu}^{2+}$ and $\mathrm{Zn}^{2}$. Carbonates calcite and dolomite were included as they are the primary buffering minerals. Anorthite and albite were included since they make up the majority of the bulk volume of the host rock. However, the neutral $\mathrm{pH}$ of the measured data suggests aluminosilicates are unlikely to dissolve. For this reason other major minerals such as clinochlore, and actinolite etc. were omitted to improve the model's simulation time. Ferrihydrite, gypsum, jarosite-k and siderite were included as secondary minerals (Table 1).

TABLE 1- REACTION STOICHIOMETRY AND SOLUBILITY PRODUCT CONSTANT (K) FOR MINERALS USED IN THE SIMULATION

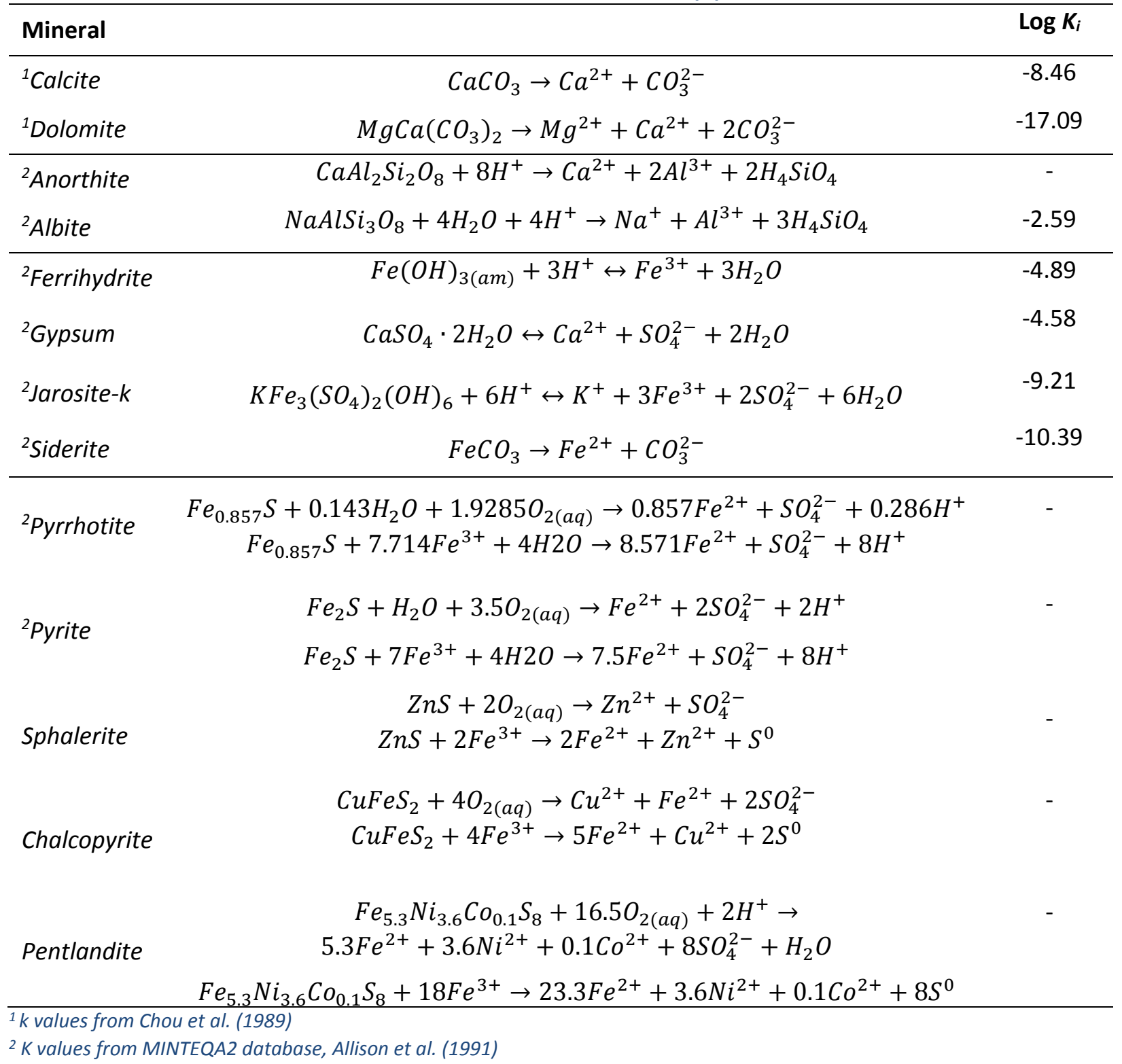




\subsubsection{Mineral Precipitation-Dissolution: Surface-Controlled Reactions}

Non-sulfide mineral precipitation-dissolution reactions are best described in MIN3P using surfacecontrolled reactions. The reaction rate for a surface-controlled dissolution-precipitation reaction $R_{k}^{m s}$ can be calculated based on the product of the reactive surface area $S_{i}\left(m_{\min }^{2} L_{b u l k}^{-1}\right)$ and a specific rate constant $k_{k}^{m}\left(\operatorname{mol}^{1-n} L_{H 2 O}^{n} m_{\min }^{-2} s^{-1}\right)$. The rate constant $k_{k}^{m}$ is a calibrated parameter inputted by the user. The rate expression for zero order reactions is as follows (from Mayer et al., 2002):

$R_{k}^{m s}=-S_{i} k_{k}^{m}\left[1-\frac{I A P_{k}^{m}}{K_{k}^{m}}\right]$

where the affinity term in equation 18 describes the lon Activity Product (IAP) of a mineral and an equilibrium constant $K_{k}$. For nth order reaction types, an additional term is needed following the specific rate constant, $\left(T_{i}\right)^{n}$, which is the total aqueous component, typically equivalent to the aqueous phase concentration ( $\mathrm{mol} \mathrm{L} \mathrm{H}_{\mathrm{H} 20}^{-3}$ ), so that equation 18 becomes (from Mayer et al., 2002):

$R_{k}^{m s}=-S_{i} k_{k}^{m}\left(T_{i}\right)^{n}\left[1-\frac{I A P_{k}^{m}}{K_{k}^{m}}\right]$

In addition, the surface area term and the rate constant can be re-written as an effective rate term (from Mayer et al., 2002):

$k_{k}^{m, e f f}\left(m o l L_{\text {bulk }}^{-3} s^{-1}\right)=S_{i} k_{k}^{m}$

For non-sulfides, the reactive surface can be held constant (used for secondary minerals) or can be updated as the mineral dissolves using a two-thirds power relationship (Lichtner, 1996). The rate equation for the change in reactive surface area is as follows (from Mayer et al., 2015):

$k_{e f f}^{t}=k_{e f f}^{o}\left[\frac{\varphi^{t}}{\varphi^{o}}\right]^{2 / 3}$

where $k_{\text {eff }}^{o}$ is the initial effective rate constant, $\varphi^{o}$ is the initial mineral volume fraction (the volume percentage of a given mineral divided by the bulk volume of the waste rock), and $k_{\text {eff }}^{t}$ and $\varphi^{t}$ are the effective rate constant and mineral volume fraction at time " $\mathrm{t}$ ", respectively.

\subsubsection{Mineral Precipitation-Dissolution: Transport-Controlled Reactions}

For iron sulfides the SCM was applied in the form of transport-controlled reactions as their rates are ultimately limited by the influx of oxygen or ferric iron through their reaction rims (Yagi and Kunii, 1955; 
Levenspiel, 1972; Davis and Ritchie, 1986; Wunderly et al., 1996). The rate expression for transportcontrolled reactions is (from Mayer et al., 2002):

$$
R_{k}^{m t}=-10^{3} S_{i} D_{k}^{m}\left[\frac{r_{i}^{p}}{\left(r_{i}^{p}-r_{i}^{r}\right) r_{i}^{r}}\right] \cdot\left[\frac{O_{2 w}}{v_{k}}\right]
$$

where $R_{k}^{m t}$ is the reaction rate for the transport-controlled dissolution-precipitation reaction (mol L-3 bulk $\left.\mathrm{T}^{-1}\right), D_{k}^{m}$ is the effective diffusion coefficient $\left(\mathrm{L}^{2} \mathrm{~T}^{-1}\right), r_{i}^{p}$ is the radius of an average mineral particle (L), $r_{i}^{r}$ is the radius of the unreacted portion of the mineral particle (L), $\mathrm{O}_{2 w}$ is the concentration of the oxidizer (usually oxygen) in water at the particle grain's surface (mol $\mathrm{Lbulk}^{-3}$ ) and $V_{k}$ is the stoichiometric coefficient of oxygen or ferric iron in the sulfide oxidation reaction. The rate expressions for all dissolution-precipitation reactions in the simulation are found in Table 2.

\subsubsection{Mineral Volume Fractions}

The weight percentages for the aluminosilicate minerals at 30 years were determined from SED-EDS analysis by McNeill (2016) and then converted into volume fractions (\% v/v bulk) for use in MIN3P. The weight percentages at 30 years' time for carbonates were estimated from carbon sulfur testing carried out by McNeill (2016). Results of this testing were organized into groups based on sieved particle size ranging from $4.76 \mathrm{~mm}$ to $0.04 \mathrm{~mm}$. Weight percentages were calculated for each group and an average value was assigned as the weight percentage of the matrix fines. Distribution of calcite and dolomite was initially set at $67 \%$ calcite and $33 \%$ dolomite based on North American averages of carbonate mineral weathering from Szramek et al. (2007).

Mineral weight percentages for sulfides were estimated from carbon sulfur testing and XRF analysis carried out by McNeill (2016). Chalcopyrite, sphalerite and pentlandite content were estimated from whole rock analysis of metals $(\mathrm{Cr}, \mathrm{Cu}, \mathrm{Ni}, \mathrm{Zn}, \mathrm{Pb})$ and subtracted from total sulfide content. Remaining sulfide content was attributed to pyrrhotite and pyrite and distributed in the ratio of $60 \%$ pyrrhotite content and $40 \%$ pyrite content as described from observations of the Detour waste rock (Robertson et al., 2012). The carbonates and sulfides were then also converted into volume fractions (volume $\% \mathrm{v} / \mathrm{v}$ bulk).

Since the calculated volume fractions represent waste rock that has experienced 30 years of weathering, the volume fractions of pyrrhotite and pyrite were increased by $10 \%$ to better reflect values from a 
theoretical fresh waste rock; whereas the percentages of pentlandite, sphalerite and chalcopyrite were adjusted to match trace metal data. Calcite and dolomite were set to be greater than the bulk calculations to guarantee enough over the course of the simulation since field observations show weight percentages of up to $2.5 \%$ in historical waste rock carbon sulfur testing (McNeill, 2016).

For the secondary minerals ferrihydrite, gypsum, jarosite-k and siderite initial volume fractions were set to a very small number since they are considered as absent at the start of the simulation. The mineral volume fractions for all minerals used in the simulation are shown in Table 2.

\subsubsection{Reaction Rates}

Dissolution-precipitation reactions for carbonates and aluminosilicates were described in MIN3P using a reactive surface area which is updated using the two-thirds power relationship (equation 21), and a pH dependent rate constant (Table 2).

For sulfide minerals, MIN3P requires the user to define a diffusion coefficient for the diffuse component of the SCM (equation 22). Sulfide dissolution is most likely occurring primarily through $\mathrm{O}_{2}$ oxidation on WRS 3 given the higher $\mathrm{pH}$ levels however, a secondary pathway was included in the model to account for any oxidation via $\mathrm{Fe}^{3+}$ should it occur. These pathways have separate calibrations for the diffusion coefficient. In addition to the diffusion coefficient for each mineral, MIN3P requires an input for the reactive surface area. The reactive surface area for sulfides is described in MIN3P as a geometric surface area ( $\mathrm{m}^{2}$ mineral $\mathrm{m}^{-3}$ porous medium) to represent the shrinking core of a reactive mineral grain (Mayer et al., 2015):

$S_{i}=3 \frac{\varphi^{t}}{r_{i}^{r}} \cdot F$

where $\varphi^{t}$ is the volume fraction at time " $t$ ", and $r_{i}^{r}$ is the radius of the unreacted portion (described in equation 22). The " $F$ " term is a scaling factor applied by MIN3P as a modification to the geometric surface area. Since a mineral grain is not a perfect sphere, the scaling factor is applied to account for the excess in surface area due to irregularities. Scaling factors from Wilson et al. (2018) were used for all sulfides save for pyrite which was not available and set to be the same as that of pyrrhotite. This was done to simplify the calibration process as neither the diffusion coefficients or the scaling factors were known from empirical measurements. The radii values for all sulfides were set at $6.25 \times 10^{-5} \mathrm{~m}$ for the overall particle radius, and $6.20 \times 10^{-5} \mathrm{~m}$ for the unreacted portion (Langman et al., 2014) since there 
were no specific measurements available. Secondary minerals were held to a constant reactive surface area and were assigned an effective rate constant to describe the reactions. Input parameters for all mineral reactions are described below in Table 2.

TABLE 2- RATE EXPRESSIONS, VOLUME FRACTIONS FOR COVER $\left(\Phi^{\circ}{ }_{1}\right)$ AND WASTE ROCK $\left(\Phi^{\circ}{ }_{2}\right)$ MATERIAL, REACTIVE SURFACE AREA $\left(S_{1}\right)$, AND RATE CONSTANTS (K) OR EFFECTIVE RATES (K $K_{\text {EFF}}$ ) OR DIFFUSION COEFFICIENTS (D) FOR ALL MINERALS IN THE SIMULATION

\begin{tabular}{|c|c|c|c|c|c|}
\hline Mineral & Rate Expression & $\varphi^{\circ}{ }_{1}$ & $\varphi^{\circ}{ }_{2}$ & $S_{i}$ & $k, k_{e f f,} D$ \\
\hline${ }^{1}$ Calcite & $\begin{array}{l}R=-S_{\text {CaCO }_{3}}\left(k_{1}\left[H^{+}\right]^{-0.051}+k_{2}\left[H_{2} O\right]^{-6.187}\right. \\
\left.\quad+k_{3}\left[H_{2} C_{3(a q)}\right]^{-3.301}\right)\left[1-\frac{I A P}{10^{8.46}}\right]\end{array}$ & $1.0 \times 10^{-2}$ & $3.5 \times 10^{-2}$ & $* 5.5 \times 10^{-3}$ & $\begin{array}{l}k 1=10^{-0.051} \\
k 2=10^{-6.187} \\
k 3=10^{-3.301}\end{array}$ \\
\hline${ }^{1}$ Dolomite & $\begin{aligned} R=-S_{M g C a\left(\mathrm{CO}_{3}\right)_{2}}( & k_{1}\left[\mathrm{H}^{+}\right]^{-2.59}+k_{2}\left[\mathrm{H}_{2} \mathrm{O}\right]^{-7.66} \\
& \left.+k_{3}\left[\mathrm{H}_{2} \mathrm{CO}_{3(a q)}\right]^{-4.00}\right)\left[1-\frac{I A P}{10^{17.09}}\right]\end{aligned}$ & $1.24 \times 10^{-4}$ & $4.4 \times 10^{-2}$ & $* 5.5 \times 10^{-3}$ & $\begin{array}{l}k 1=10^{-2.59} \\
k 2=10^{-7.66} \\
k 3=10^{-4.00}\end{array}$ \\
\hline${ }^{2}$ Anorthite & $R=-S_{\mathrm{CaAl}_{2} \mathrm{Si}_{2} \mathrm{O}_{8}}\left(k_{1}\left[H^{+}\right]^{-5.87}\right)$ & $1.42 \times 10^{-4}$ & $1.42 \times 10^{-1}$ & $* 6.0 \times 10^{-5}$ & $k=10^{-5.87}$ \\
\hline${ }^{2}$ Albite & $\left.\left.I^{+}\right]^{-9.69}+k_{2}\left[H^{+}\right]^{-14.15}\right)$ & $8.06 \times 10^{-5}$ & $8.06 \times 10^{-2}$ & $* 6.0 \times 10^{-3}$ & $\begin{array}{l}k 1=10^{-9.69} \\
k 2=10^{-14.15}\end{array}$ \\
\hline${ }^{3}$ Ferrihydrite & $R=k_{\left(\mathrm{Fe}^{3+}\right)_{2} \mathrm{O}_{3} \cdot 0.5 \mathrm{H}_{2} \mathrm{O}}^{e f f}\left[1-\frac{I A P}{10^{4.89}}\right]$ & $1.0 \times 10^{-10}$ & $1.0 \times 10^{-10}$ & - & $K_{\text {eff }}=10^{-7.097}$ \\
\hline${ }^{3}$ Gypsum & $R=k_{\text {CaSO }_{4} \cdot 2 \mathrm{H}_{2} \mathrm{O}}^{e f f}\left[1-\frac{I A P}{10^{4.58}}\right]$ & $1.0 \times 10^{-10}$ & $1.0 \times 10^{-10}$ & - & $K_{\text {eff }}=10^{-4.699}$ \\
\hline 3Jarosite-k & $R=k_{\mathrm{KFe}_{3}\left(\mathrm{SO}_{4}\right)_{2}(\mathrm{OH})_{6}}^{e f f}\left[1-\frac{I A P}{10^{-9.21}}\right]$ & $1.0 \times 10^{-10}$ & $1.0 \times 10^{-10}$ & - & $K_{\text {eff }}=10^{-8.699}$ \\
\hline${ }^{3}$ Siderite & $R=k_{\mathrm{FeCO}_{3}}^{e f f}\left[1-\frac{I A P}{10^{10.39}}\right]$ & $1.0 \times 10^{-10}$ & $1.0 \times 10^{-10}$ & - & $K_{\text {eff }}=10^{-7.097}$ \\
\hline \multirow[t]{2}{*}{${ }^{4}$ Pyrrhotite } & $R_{O_{2}}=-10^{3} S_{F e_{0.857} S}\left[\frac{r^{p}}{\left(r^{p}-r^{r}\right) r^{r}}\right] D_{O_{2(a q)}}\left[\frac{O_{2(a q)}}{1.9285}\right]$ & \multirow[b]{2}{*}{$1.05 \times 10^{-9}$} & \multirow[b]{2}{*}{$3.05 \times 10^{-3}$} & $2.8 \times 10^{-3}$ & $D=10^{-14.13}$ \\
\hline & $R_{F e^{3+}}=-10^{3} S_{F e_{0.857} S}\left[\frac{r^{p}}{\left(r^{p}-r^{r}\right) r^{r}}\right] D_{F e^{3+}}\left[\frac{F e^{3+}}{7.714}\right]$ & & & $1.5 \times 10^{-2}$ & $D=10^{-19.193}$ \\
\hline \multirow[t]{2}{*}{${ }^{4}$ Pyrite } & $R_{O_{2}}=-10^{3} S_{F e_{2} S}\left[\frac{r^{p}}{\left(r^{p}-r^{r}\right) r^{r}}\right] D_{O_{2(a q)}}\left[\frac{O_{2(a q)}}{3.50}\right]$ & \multirow{2}{*}{$3.07 \times 10^{-7}$} & \multirow{2}{*}{$1.20 \times 10^{-3}$} & $3.7 \times 10^{-3}$ & $D=10^{-14.13}$ \\
\hline & $R_{F e^{3+}}=-10^{3} S_{F_{2} S}\left[\frac{r^{p}}{\left(r^{p}-r^{r}\right) r^{r}}\right] D_{F e^{3+}}\left[\frac{F e^{3+}}{7.00}\right]$ & & & $6.9 \times 10^{-3}$ & $D=10^{-19.193}$ \\
\hline \multirow[t]{2}{*}{${ }^{4}$ Sphalerite } & $R_{O_{2}}=-10^{3} S_{Z n S}\left[\frac{r^{p}}{\left(r^{p}-r^{r}\right) r^{r}}\right] D_{O_{2(a q)}}\left[\frac{O_{2(a q)}}{2.00}\right]$ & \multirow{2}{*}{$3.51 \times 10^{-10}$} & \multirow{2}{*}{$3.51 \times 10^{-5}$} & $1.3 \times 10^{-9}$ & $D=10^{-16.62}$ \\
\hline & $R_{F e^{3+}}=-10^{3} S_{Z n S}\left[\frac{r^{p}}{\left(r^{p}-r^{r}\right) r^{r}}\right] D_{F e^{3+}}\left[\frac{F e^{3+}}{2.00}\right]$ & & & $1.4 \times 10^{-4}$ & $D=10^{-19.939}$ \\
\hline \multirow[t]{2}{*}{${ }^{4}$ Chalcopyrite } & $R_{O_{2}}=-10^{3} S_{\text {CuFeS }_{2}}\left[\frac{r^{p}}{\left(r^{p}-r^{r}\right) r^{r}}\right] D_{O_{2(a q)}}\left[\frac{O_{2(a q)}}{4.00}\right]$ & \multirow{2}{*}{$1.58 \times 10^{-10}$} & \multirow{2}{*}{$1.58 \times 10^{-5}$} & $6.6 \times 10^{-10}$ & $D=10^{-18.026}$ \\
\hline & $R_{F^{3+}}=-10^{3} S_{\text {CuFeS }_{2}}\left[\frac{r^{p}}{\left(r^{p}-r^{r}\right) r^{r}}\right] D_{F e^{3+}}\left[\frac{F e^{3+}}{4.00}\right]$ & & & $6.6 \times 10^{-5}$ & $D=10^{-19.461}$ \\
\hline
\end{tabular}




$$
\begin{aligned}
& { }^{4} \text { Pentlandite } \quad R_{O_{2}}=-10^{3} S_{\left(F e_{5.30} N i_{3.60} C O_{0.10}\right) S_{9}}\left[\frac{r^{p}}{\left(r^{p}-r^{r}\right) r^{r}}\right] D_{O_{2(a q)}}\left[\frac{O_{2(a q)}}{16.50}\right]
\end{aligned}
$$

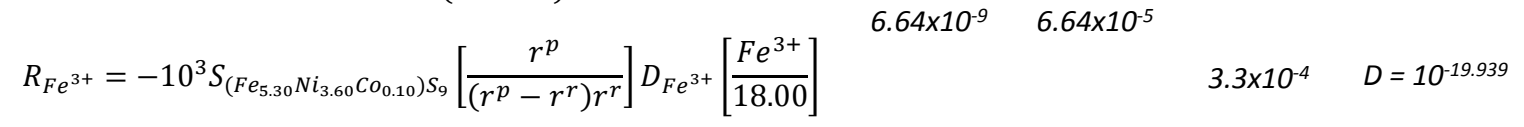

*Reactive surface area calibrated for the simulation

${ }^{1} \mathrm{k}$ values from Chou et al. (1989)

$2 k$ values from Blum and Stillings (1995)

${ }^{3} k_{\text {eff }}$ calibrated for the simulation

${ }^{4}$ Geometric surface areas (for cover and waster rock) calculated using $r_{i}^{r}=0.0625 \mathrm{~mm}$ (Langman et al., 2014), calibrated diffusion rates and scaling factors

\subsection{Soil Parameters}

Cash (2014) completed hydrological analysis of ten field samples to determine flow characteristics of cover material and matrix fines (described as the material passing the $4.76 \mathrm{~mm}$ sieve). These fines represent $17 \%$ of the total waste rock and are where capillary flow and primary generation of AMD will take place. Saturated hydraulic conductivities were calculated from constant head permeability testing, while volumetric water was determined from Tempe pressure cells. Soil water characteristic curves (SWCC's) were produced from this analysis following the methods of Fredlund and Xing (1994). The air entry values (AEV) and residual water saturations were determined for each sample from these SWCC's. Porosity of the fine-grained waste rock was calculated by Cash (2014) from SWCC Tempe cell tests, whereas the cover material porosity of 0.54 is from $\mathrm{ECH}_{2} \mathrm{O}$ probe data from McNeill (2016) (Table 3).

Van Genuchten (V.G.) parameters of $\alpha$ and $n$, were determined by fitting to the SWCC using the least squares method (Table 3). To incorporate these values into the MIN3P simulation, average values for the different waste rock piles and the cover material were calculated. (Table 3). Due to the heterogeneous nature of waste rock, hydrological properties throughout were then further calibrated to match observed soil moisture data obtained from $\mathrm{ECH}_{2} \mathrm{O}$ probes (Steinepreis, 2017).

TABLE 3- SUMMARY OF HYDRAULIC PARAMETERS CALCULATED FROM SAMPLES COLLECTED BY CASH (2014) AND MCNEILL (2016), AND AVERAGE HYDRAULIC PARAMETERS FOR COVER AND WASTE ROCK MATERIAL FOR USE IN MIN3P

\begin{tabular}{ccccccc}
\hline \multirow{6}{*}{ Sample } & $\begin{array}{c}\text { Hydraulic } \\
\text { Conductivity } \\
(\mathbf{m} / \mathbf{s})\end{array}$ & ${ }^{R}$ Porosity & $\begin{array}{c}{ }^{\top} \text { Residual } \\
\text { Saturation } \\
(\text { vol\%) }\end{array}$ & $*_{\boldsymbol{\alpha}}$ & $*_{\mathbf{n}}$ \\
\hline \multirow{3}{*}{ Cover } & TP-P1-S4-S1 & $2.40 \times 10^{-4}$ & 0.54 & 3.6 & 0.03 & 2.76 \\
& $T P-P 1-S 14-S 1$ & $4.10 \times 10^{-5}$ & 0.54 & 17.0 & 0.15 & 10.53 \\
& $T P-P 2-S 11-S 1$ & $1.30 \times 10^{-6}$ & 0.54 & 7.2 & 0.03 & 5.93 \\
\hline \multirow{6}{*}{ WRS \#1 } & $T P-P 1-S 5-S 3$ & $7.60 \times 10^{-5}$ & 0.007 & 5.5 & 0.02 & 10.38 \\
& $T P-P 1-S 6-S 3$ & $1.50 \times 10^{-5}$ & 0.066 & 7.0 & 0.13 & 3.28 \\
& $T P-P 1-S 9-S 1$ & $5.40 \times 10^{-6}$ & 0.105 & 12.0 & 0.07 & 14.22
\end{tabular}




\begin{tabular}{ccccccc} 
& $T P-P 1-S 11-S 2$ & $1.20 \times 10^{-5}$ & 0.102 & 2.4 & 0.02 & 14.00 \\
& $P 1-P 3-S 2$ & $1.40 \times 10^{-5}$ & 0.046 & 8.3 & 0.02 & 13.49 \\
& $P 1-P 6-S 1$ & $N / A$ & 0.041 & 1.8 & 0.02 & 5.06 \\
\hline \multirow{3}{*}{ WRS\#2 } & $T P-P 2-S 10-S 3$ & $1.80 \times 10^{-5}$ & 0.128 & 5.5 & 0.08 & 15.07 \\
& $T P-P 2-S 13-S 3$ & $3.10 \times 10^{-6}$ & 0.052 & 13.5 & 0.06 & 6.52 \\
& $T P-P 2-S 16-S 3$ & $2.20 \times 10^{-5}$ & 0.054 & 5.2 & 0.08 & 10.74 \\
& WRS-2-12 & $7.30 \times 10^{-6}$ & 0.067 & 7.9 & 1.11 & 1.57 \\
\hline
\end{tabular}

\begin{tabular}{cccccc}
\hline \multicolumn{7}{c}{ Soil parameter averages } \\
\hline${ }^{1}$ Cover & $9.41 \times 10^{-5}$ & 0.54 & 9.3 & 0.0697 & 6.405 \\
${ }^{1}$ WRS 1 & $2.45 \times 10^{-5}$ & 0.061 & 6.2 & 0.045 & 9.902 \\
${ }^{1}$ WRS2 & $1.30 \times 10^{-5}$ & 0.076 & 8 & 0.3312 & 8.475 \\
\hline
\end{tabular}

Calibrated Soil Parameters in MIN3P

\begin{tabular}{cccccc}
\hline${ }^{2}$ Cover & $1.80 \times 10^{-5}$ & 0.54 & 9.3 & 0.25 & 4 \\
${ }^{2}$ Waste Rock & $1.50 \times 10^{-5}$ & 0.075 & 7 & 0.185 & 9.1 \\
\hline
\end{tabular}

${ }^{R}$ Average porosity for cover material from McNeill (2016), effective porosities for waste rock from Cash (2014)

${ }^{\top}$ Based on SWCC from Cash (2014)

${ }^{*}$ Calculated using Equation (11) and the sum of squares function in Excel

${ }^{1}$ Averaged values from Cash (2014) and calculations for $\alpha$ and $n$

${ }^{2}$ Calibrated values for use in MIN3P based on pore saturation data from ECH2O probes

\subsection{Variably Saturated Flow Parameters}

Infiltration rates for the Detour Gold Mine were estimated using the Penman-Monteith

Evapotranspiration (FAO-56) Method (Appendix A). Onsite precipitation data spanning several decades

for the Detour Gold Mine was non-existent. Data from the NRCAN database was retrieved from the weather station in Kapuskasing, Ontario, which is situated $200 \mathrm{~km}$ south west from the mine and represents a close approximation of the climate and precipitation. In addition to irradiance and wind speed data, this station had a near complete precipitation record spanning the life of the previous Detour Lake Mine.

To properly estimate the infiltration on site, several assumptions were made. First monthly averages of irradiance, wind speed, and precipitation were calculated based on 30 years of precipitation data. This allows anomalies and inconsistencies to be averaged out over time and have less of an impact on the infiltration rate. Infiltration was assumed to be zero for the months of December through to March. McNeill (2016) showed the upper $5 \mathrm{~m}$ of waste rock material falls below $0{ }^{\circ} \mathrm{C}$ during the winter months, and it is assumed the pore water is frozen, therefore preventing any infiltration. November rain was considered as infiltration only on days with no snow cover to represent milder temperatures. In the spring, increased infiltration from a melting snow pack must be accounted for. The estimated melt water 
coming from the snow pack is known as the Snow Water Equivalent (SWE). The water from the snow pack varies based on snow depth, snow density and the variable onset of sublimation during the winter months. The snow water equivalent calculations corrected for sublimation are described in Appendix A. The monthly infiltration averages $(\mathrm{mm})$ after 30 years were converted into infiltration rates $(\mathrm{m} / \mathrm{s})($ Table 4). The total annual infiltration after evapotranspiration corrections is approximately $450.43 \mathrm{~mm}$ or 53 $\%$ of the $851 \mathrm{~mm}$ annual average estimated from the Kapuskasing, Ontario, weather station.

TABLE 4- CHART OF MONTHLY INFILTRATION RATES AND FLOW RATES USED IN THE MIN3P SIMULATION

\begin{tabular}{|c|c|c|c|c|c|c|c|c|c|c|c|c|}
\hline & Jan. & Feb. & Mar. & Apr. & May & Jun. & Jul. & Aug. & Sept. & Oct. & Nov. & Dec. \\
\hline $\begin{array}{c}\text { Monthly } \\
\text { Infiltration }(\mathrm{mm})\end{array}$ & 0 & 0 & 0 & 41.8 & 48 & 66.3 & 76.9 & 67.5 & 84.5 & 54.1 & 11.4 & 0 \\
\hline $\begin{array}{l}\text { *Infiltration } \\
\text { Rate }(\mathrm{m} / \mathrm{s})\end{array}$ & 0 & 0 & 0 & 1.6 & 1.8 & 2.5 & 2.9 & 2.6 & 3.2 & 2.1 & 0.4 & 0 \\
\hline
\end{tabular}

Values are corrected for evapotranspiration, sublimation and SWE

*Infiltration rates are to the power of $1 \times 10^{-8}$

Initial conditions in the column were set at a hydraulic head of $1 \mathrm{~m}$. At the top, flow entering the column was defined as transient with a constant flux defined by monthly average infiltration rates. The bottom of the column was set at a constant head of $1 \mathrm{~m}$ allowing the water to freely drain from the column into the water table. The geochemical composition of the input water was estimated from the closest water sample data from Rutherford (1967), with additional ion concentrations data supplemented from Wilson et al. (2018) (Table 5).

TABLE 5- INPUT WATER ION CONCENTRATION (MG/L)

\begin{tabular}{|c|c|c|c|c|c|}
\hline Ion & Concentration (mg/L) & Ion & Concentration $(\mathrm{mg} / \mathrm{L})$ & Ion & Concentration (mg/L) \\
\hline$A l^{+3}$ & $8.8 E-03$ & $\mathrm{CO}_{3}^{-2}$ & $3.75 E-01$ & $\mathrm{H}_{4} \mathrm{SiO}_{4}$ & $2.3 E-01$ \\
\hline$B a^{+2}$ & $2.0 E-02$ & $\mathrm{Cr}^{+2}$ & $1.0 E-10$ & $K^{+}$ & $4.6 E-01$ \\
\hline$B r^{-}$ & $1.0 E-10$ & $\mathrm{Cu}^{+2}$ & $1.3 E-03$ & $M g^{+2}$ & $1.8 E-01$ \\
\hline $\mathrm{Ca}^{+2}$ & 8.9 & $\mathrm{Fe}^{+2}$ & $6.8 E-04$ & $\mathrm{Na}^{+}$ & $2.0 E-01$ \\
\hline $\mathrm{Cd}^{+2}$ & $1.0 E-10$ & $\mathrm{Fe}^{+3}$ & $1.0 E-10$ & $\mathrm{Ni}^{+2}$ & $3.5 E-03$ \\
\hline $\mathrm{CO}^{+2}$ & $3.0 E-04$ & $H S^{-}$ & $1.0 E-10$ & $S_{o}$ & 1.2 \\
\hline$Z n^{+2}$ & $1.1 E-02$ & $P b^{+2}$ & $1.0 E-10$ & $\mathrm{SO}^{-2}$ & 1.5 \\
\hline & & $O_{2(a q)}$ & 8.0 & & \\
\hline
\end{tabular}

Values adjusted from Rutherford (1967)

\subsection{Reactive Transport Parameters}

Initial conditions for both the cover material and the waste rock had water geochemistry identical to that of the input water (Table 5). A fixed atmospheric gas pressure boundary was assigned with a free 
exit condition set for outflow. For both the waste rock and cover a longitudinal dispersivity of $0.01 \mathrm{~m}$ was assigned (Wilson et al., 2018). The pore gas values for $\mathrm{CO}_{2}$ and $\mathrm{O}_{2}$ fluctuate daily within the waste rock pile and are dependent on many factors such as advective transport, wind speed and direction, and temperature (Steinepreis, 2017). Since MIN3P is not able to simulate these fluctuations, the gas diffusion coefficient was calibrated to reproduce $\mathrm{CO}_{2}$ and $\mathrm{O}_{2}$ values that fall within the observed range. The gas diffusion coefficient was set at $1.0 \times 10^{-5}\left(\mathrm{~m}^{2} \mathrm{~s}^{-1}\right)$ in accordance to this calibration. The aqueous diffusion coefficient was set at $2.38 \times 10^{-9}\left(\mathrm{~m}^{2} \mathrm{~s}^{-1}\right)$ to represent an average value for all components. MIN3P calculates effective diffusion based on equation 17.

\section{Chapter 4: Results and Discussion}

\subsection{Flow System}

\subsubsection{Pore Saturation}

Soil parameters were adjusted to resemble the moisture profiles of the waste rock on WRS 3 (Figure 4) so that moisture content during a simulated year was not to exceed the minimum and maximum values attained from $\mathrm{ECH}_{2} \mathrm{O}$ probes (Steinepreis, 2017).

4a)

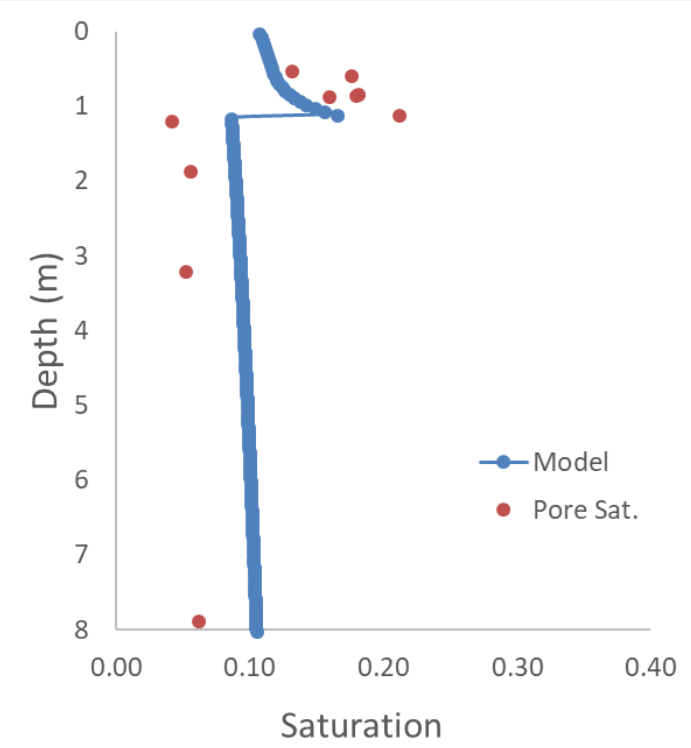

FIGURE 4- GRAPHS OF PORE SATURATION WITH DEPTH PLOTTED WITH THE MODEL SIMULATION (SOLID LINE) WITH (A) SHOWING LOW SATURATION AT 29.2 YEARS, AND (B) HIGH SATURATION AT 29.8 YEARS 
The seasonal trends from the simulation (Figure 5) capture the onset of wetting fronts and melt water. The data from $\mathrm{ECH}_{2} \mathrm{O}$ probes from September, 2014, to August, 2015, demonstrated large changes in saturation associated with wetting fronts and snow melt at shallow depts. For hole 3-1 at $1.18 \mathrm{~m}$, wetting fronts associated with rain infiltration are observed in mid-September, early October, July, and late August. The largest change in saturation is associated with periods of intense rain in October. An increase in saturation at the end of May lasting until end of June is associated with spring rain and snow melt. At 3.18 m only a spike in October is observed. For hole $3-2$ at $1.85 \mathrm{~m}$, similar wetting fronts exist from September through to October with an additional one in November. At $3.18 \mathrm{~m}$, increases in saturation with longer drainage times are observed for September, October and May (Steinepreis, 2017).

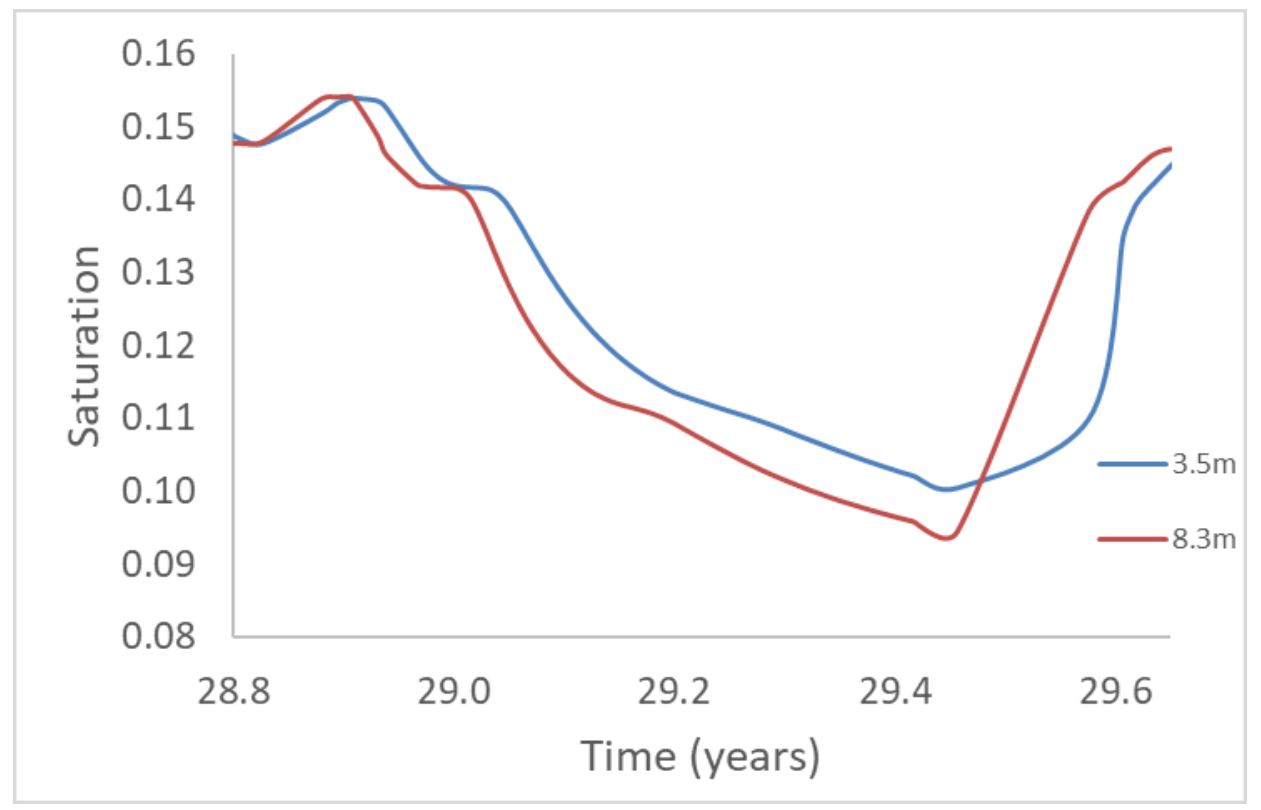

Figure 5 - Model SEASONAL SATURATION TRENDS AT 3.5 M AND 8.3 M

The location of $\mathrm{ECH}_{2} \mathrm{O}$ probes were not limited to finer matrix material (less than $4.76 \mathrm{~mm}$ ) and therefore are not a perfect representation. Matrix fines have a larger residual saturation and less void space that can be filled during periods of heavy infiltration. In addition to this, the finer material only represents approximately $17 \%$ of total waste rock material (Cash, 2014; Steinepreis, 2017). 


\subsubsection{Residence Time}

A bromide tracer test was simulated to examine the residence time of the numerical model. Pore water saturation levels varied from $9.8 \%$ to $15.6 \%$ stabilizing after two years. A bromide tracer was fed into the system with a concentration of $10 \mathrm{mg} / \mathrm{L}$ at the start of year 3 for a total of one year (Figure 6).

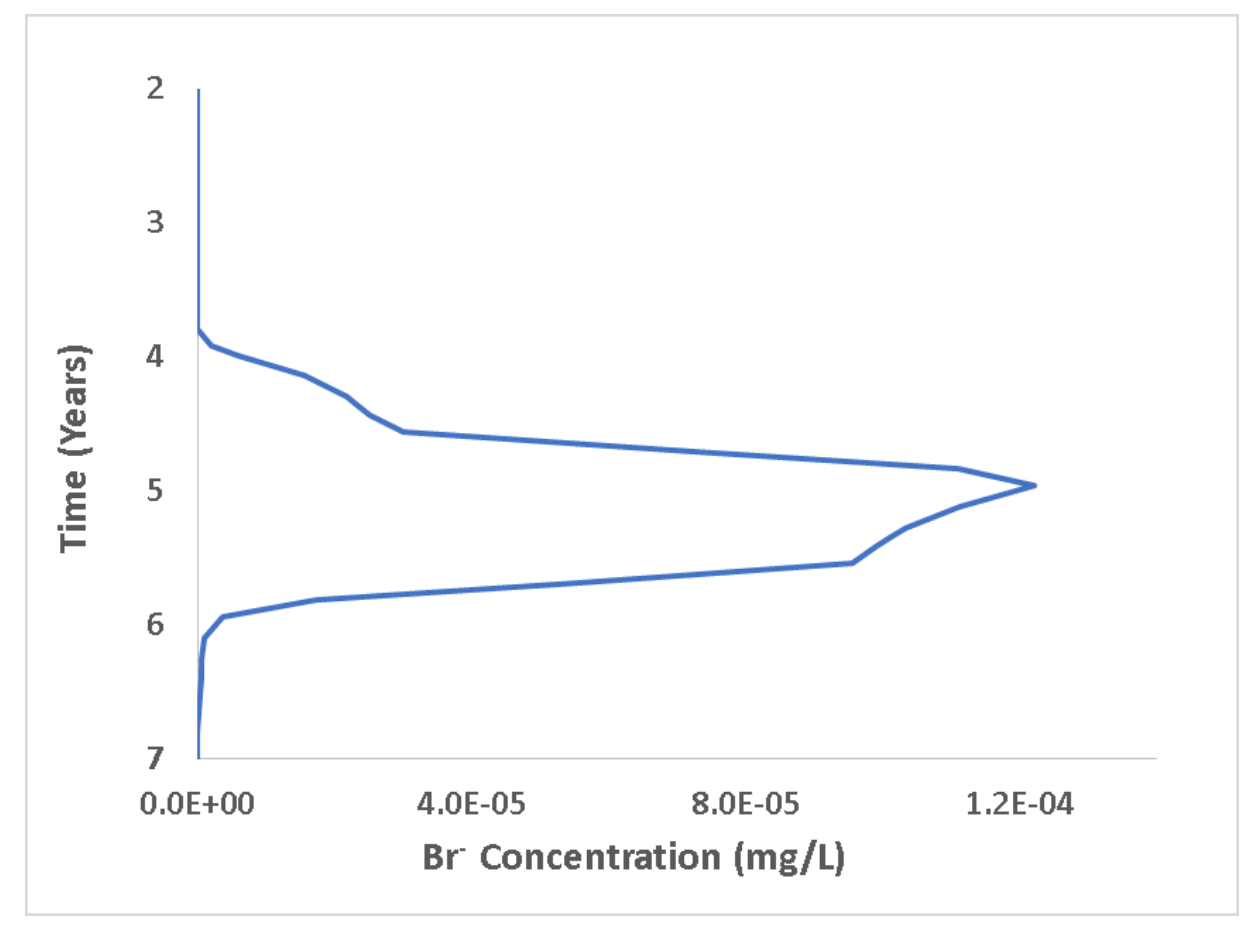

FIGURE 6 - GRAPH OF BROMIDE TRACER PULSE ARRIVAL TIME AT 16 M

Peak arrival of the bromide peak was at a concentration of $1.22 \times 10^{-4} \mathrm{mg} / \mathrm{L}$ at 4.97 years. In comparison, the REV simulation from Cash (2014) using data from the DIP analysis and an average annual precipitation of $880 \mathrm{~mm} / \mathrm{yr}$ obtained from the Cochran, Ontario weather station, was used to gather residual moisture values and residence times. Residence times for the $1 \mathrm{~m} \times 1 \mathrm{~m}$ column simulation ranged from 10 days to 19.7 days. This is equivalent to 0.44 years to 0.86 years for a $16 \mathrm{~m}$ column with $100 \%$ infiltration. These residence times are relatively short, but not surprising. The model assumed a steady state, that all pores were connected, $100 \%$ infiltration was occurring and did not consider runoff, lateral flow and evaporation.

Additionally, the constructed pile experiment of Nichol et al., (2005) had much slower residence times of 4.4 years for a $5 \mathrm{~m}$ column with an annual precipitation of $303 \mathrm{~mm} / \mathrm{yr}$ and $55 \%$ infiltration. For a $16 \mathrm{~m}$ column the equivalent is $\sim 14.1$ years. Waste rock heterogeneity allows for several different flow paths 
which would result in a variation of arrival times. Nichol et al., (2005) concluded modeling of a single flow path is not enough to characterize flow within a waste rock pile. Nevertheless, the residence time given by the bromide seems reasonable for a column made up of matrix fines with yearly precipitation rates of $851 \mathrm{~mm}$ and an infiltration of $53 \%$.

\section{3 Gas Concentration}

The $\mathrm{O}_{2}$ and $\mathrm{CO}_{2}$ concentrations show an increase in $\mathrm{CO}_{2}$ and decrease in $\mathrm{O}_{2}$ with depth, similar to field data, with only slight fluctuations during a year at less than a percent at any given depth (Figure 7). It is worth mentioning that due to seasonal variability the water table fluctuated in field observations (Steinepreis, 2017), leading to some measured values appearing below the simulation's water table set at $16 \mathrm{~m}$ depth. 


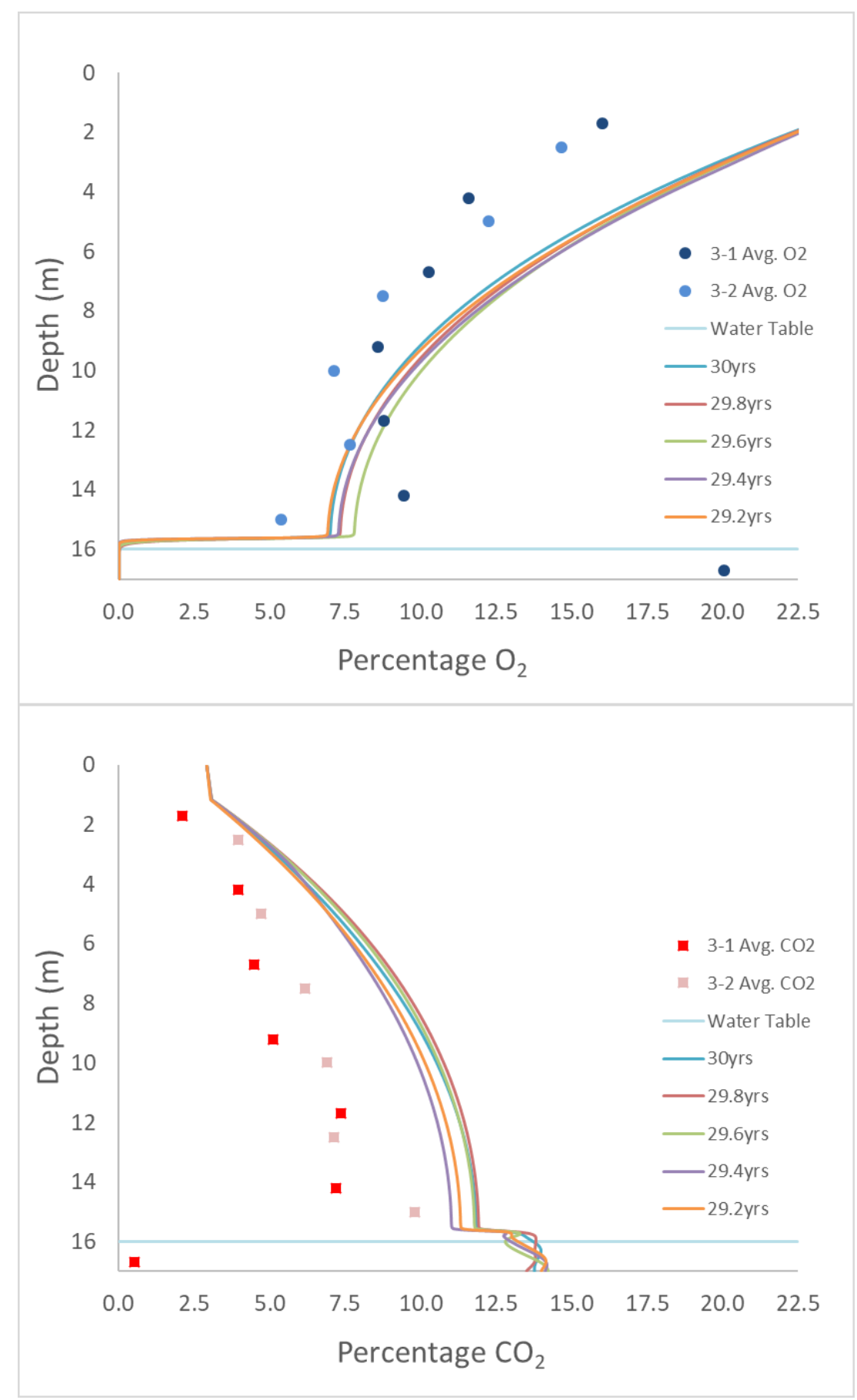

Figure 7 - MOdel $\mathrm{O}_{2}$ AND $\mathrm{CO}_{2}$ GAS CONCENTRATIONS WITH DEPTH FROM 29.2 YEAR TO 30 YEARS, PLOTTED WITH AVERAGES FROM HOLE 3-1 AND 3-2

The concentrations at year 30 were the most representative of average $\mathrm{O}_{2}$ and $\mathrm{CO}_{2}$ concentrations and are used in comparison to field data. The levels of $\mathrm{CO}_{2}$ were marginally higher than average but were 
lower than the maximum levels of $\mathrm{CO}_{2}$ indicated by field data which exceeded $15 \%$ on occasion (Figure 8). Minimum values for $\mathrm{CO}_{2}$ were below the detection limit of $0.1 \%$ in field observations. The model $\mathrm{O}_{2}$ concentrations were above the average $\mathrm{O}_{2}$ levels from field data particularly at $10 \mathrm{~m}$ and above.

Atmospheric levels of $\mathrm{O}_{2}$ were observed at all depths in the field data with minimum values for $\mathrm{O}_{2}$ averaging less than $1 \%$ (Figure 9).

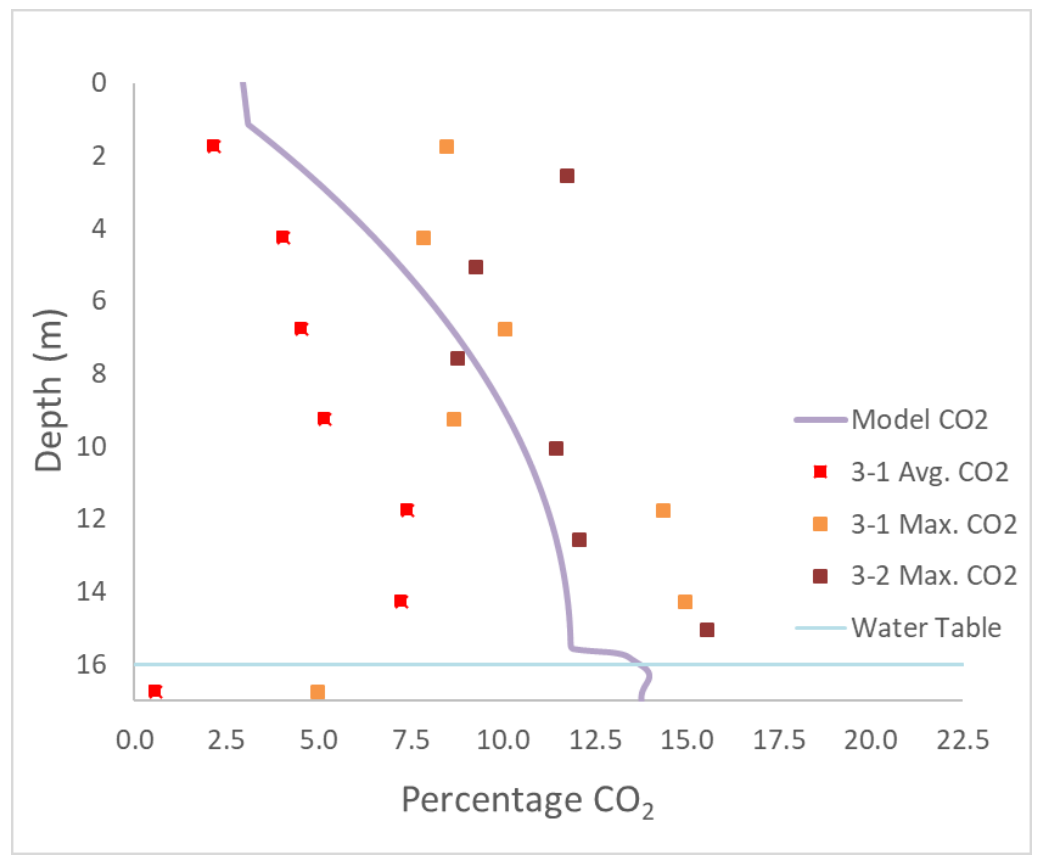

FigURE 8 - MOdeL $\mathrm{CO}_{2}$ LEVELS PLOTTED WITH AVERAGE AND MINIMUM $\mathrm{CO}_{2}$ LEVELS FOR HOLES 3-1 AND 3-2 


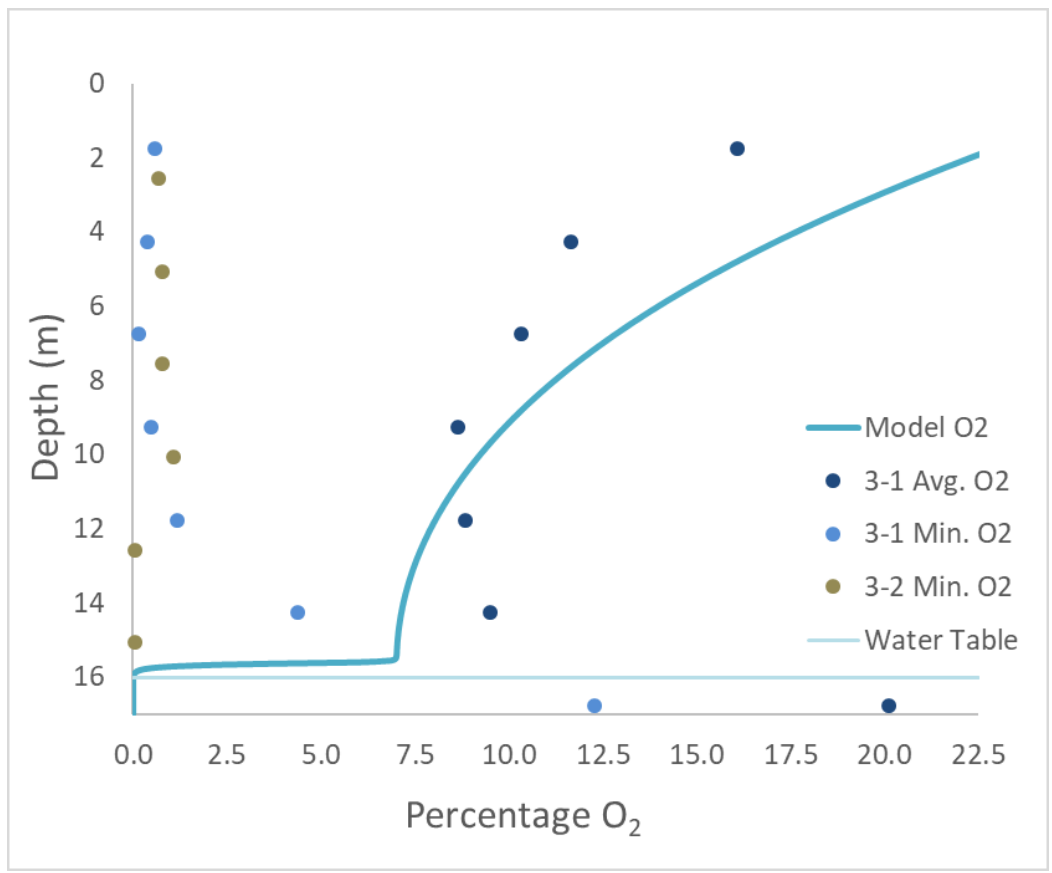

Figure 9- Model $\mathrm{O}_{2}$ LeVels Plotted With AVERAGe AND Minimum $\mathrm{O}_{2}$ LEVelS For HOles 3-1 AND 3-2

It is unclear whether the higher than average oxygen levels at shallower depths may be the result of the model underpredicting the sulfide oxidation, or the discrepancy is due to the simplifications in gas transport processes discussed above in Section 3.6. However, sulfide oxidation rates are constrained by several model parameters that will be discussed below.

\subsection{Seasonal Variance}

The pore water geochemistry varied over the course of the year and seems to be linked closely with the rate of infiltration as the gas concentrations fluctuated by less than $1 \%$. While the trace metals and $\mathrm{pH}$ remained relatively stable, sulfate and total iron were the most variable along with $\mathrm{Ca}^{2+}$ and $\mathrm{Mg}^{2+}($ Figure 9). Save for alkalinity and $\mathrm{pH}$, the influx due to spring rains and snow melt can be seen at 29.4 years at the $5 \mathrm{~m}$ depth interval before dropping off sharply. The influence of this pulse can then be seen at a depth of $10 \mathrm{~m}$ just before 29.6 years, and again at a depth of $15 \mathrm{~m}$ at 29.7 years. Alkalinity and pH increase due to this event, but the effects are delayed and not as dramatic (Figure 10). For trace metals the change in concentration is subtler with $\mathrm{Zn}^{2+}$ having the most dynamic changes at each depth. The increase in metal concentrations from the spring influx is a bit delayed at $10 \mathrm{~m}$ and $15 \mathrm{~m}$ depth, arriving at 29.6 years and 29.8 years, respectively (Figure 11 ). 

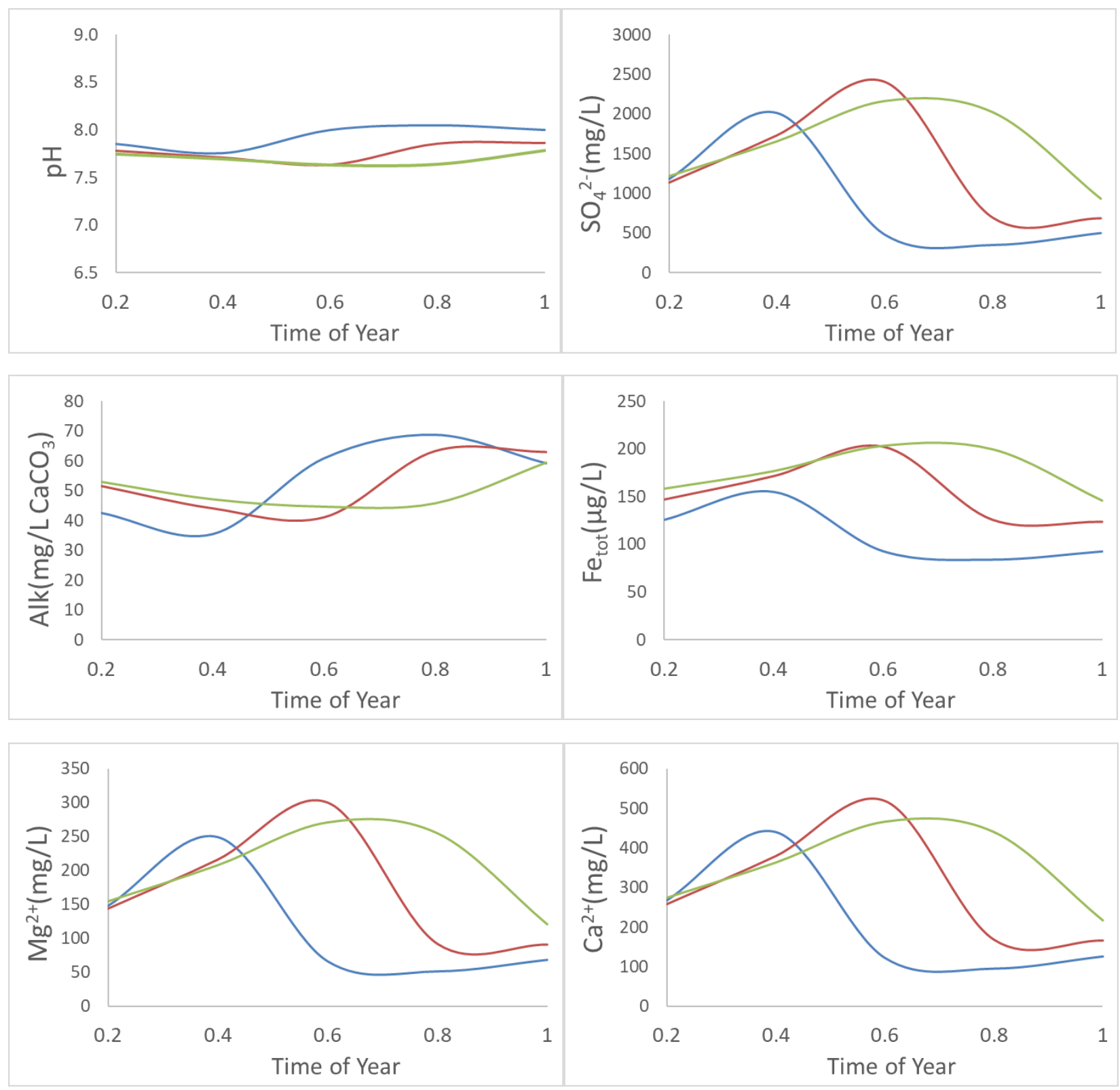

FigURE 10 - SiMULATED WATER GEOCHEMISTRY VARIANCE AT 5 M (BLUE) DEPTH, 10 M (RED) DEPTH AND 15 M DEPTH (GREEN) FROM 29.2 YEARS TO 30 YEARS. 

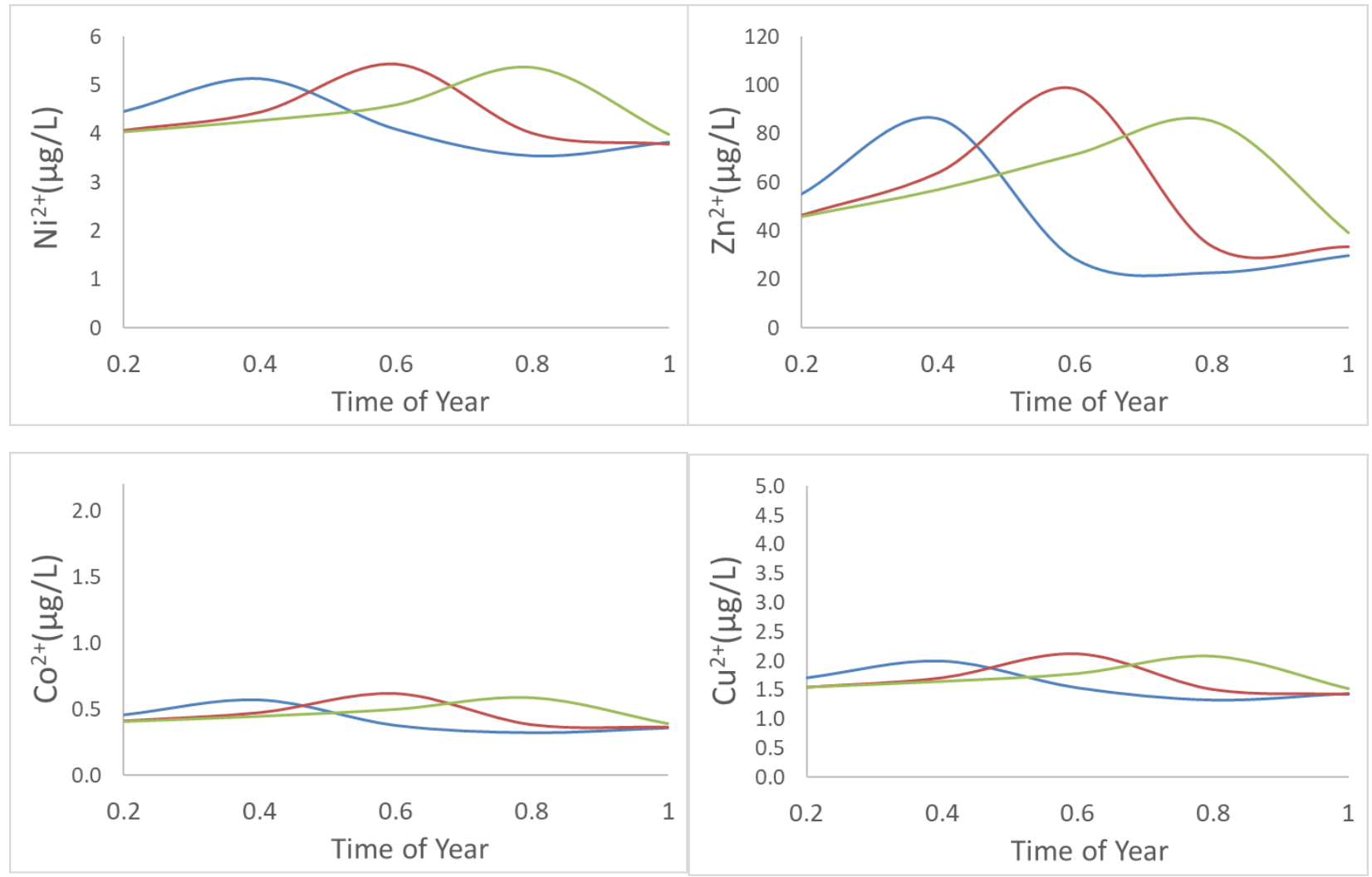

FIGURE 11 - SiMULATED WATER GEOCHEMISTRY VARIANCE AT 5 M (BLUE) DEPTH, 10 M (RED) DEPTH AND 15 M DEPTH (GREEN) FOR TRACE METALS FROM 29.2 YEARS TO 30 YEARS.

A similar trend of seasonal variance over the course of a given year is observed in the pore water samples from field data, although the trends are less distinguished. The fluctuations are most likely due to differences in rainfall, snow depth and temperature year to year. Below are plots of the simulated seasonal trends at $5 \mathrm{~m}$ along with pore water geochemistry collected at $5 \mathrm{~m}$ (Figures 12 and 13). Additional plots for $10 \mathrm{~m}$ and $15 \mathrm{~m}$ are in the Appendix (see Figures 26 to 29). 


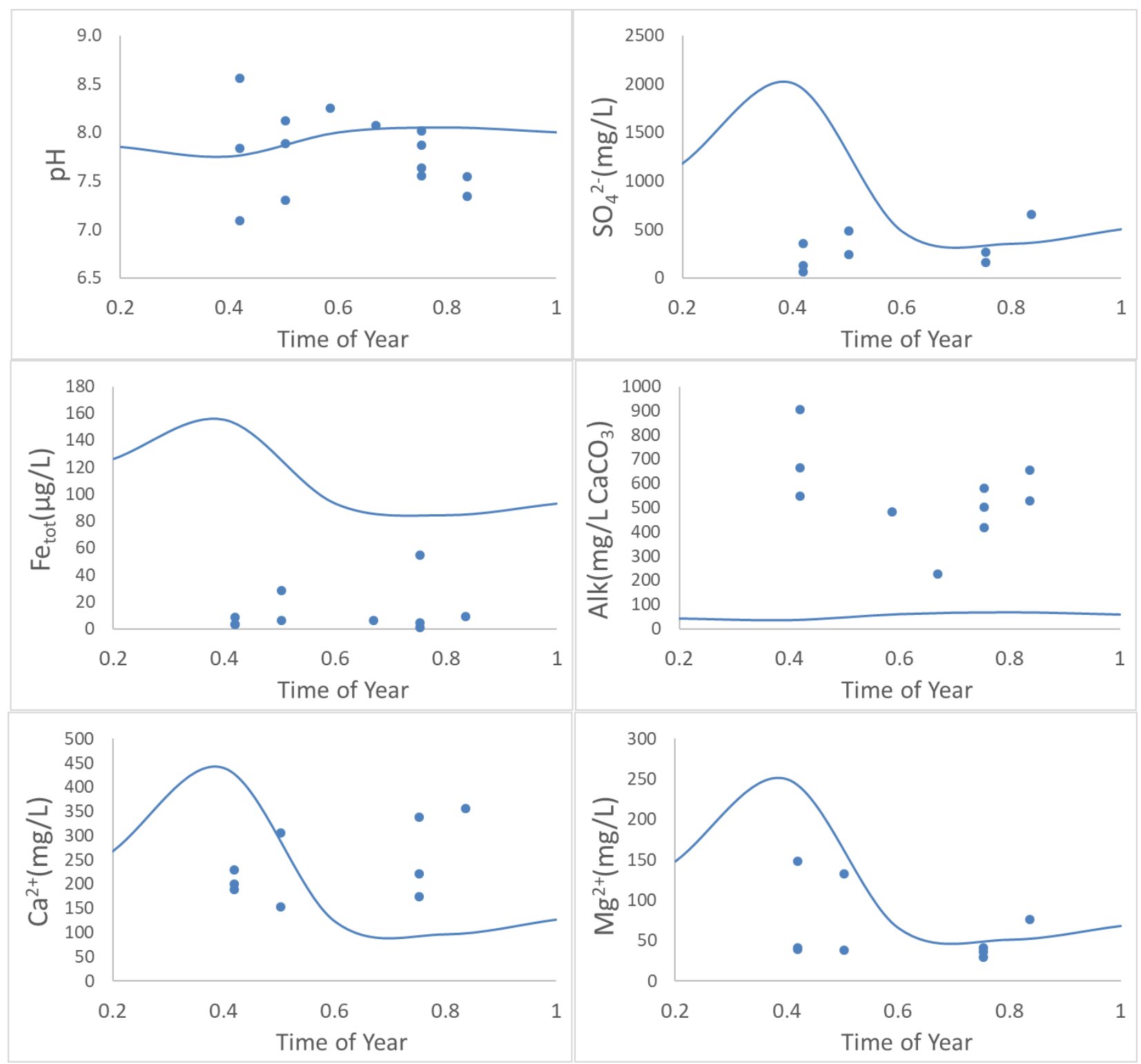

FIGURE 12 - SIMULATED WATER GEOCHEMISTRY VARIANCE AT 5 M FOR THE $29^{\text {TH }}$ YEAR, PLOTTED WITH PORE WATER GEOCHEMISTRY COLLECTED AT 5 M DEPTH. 

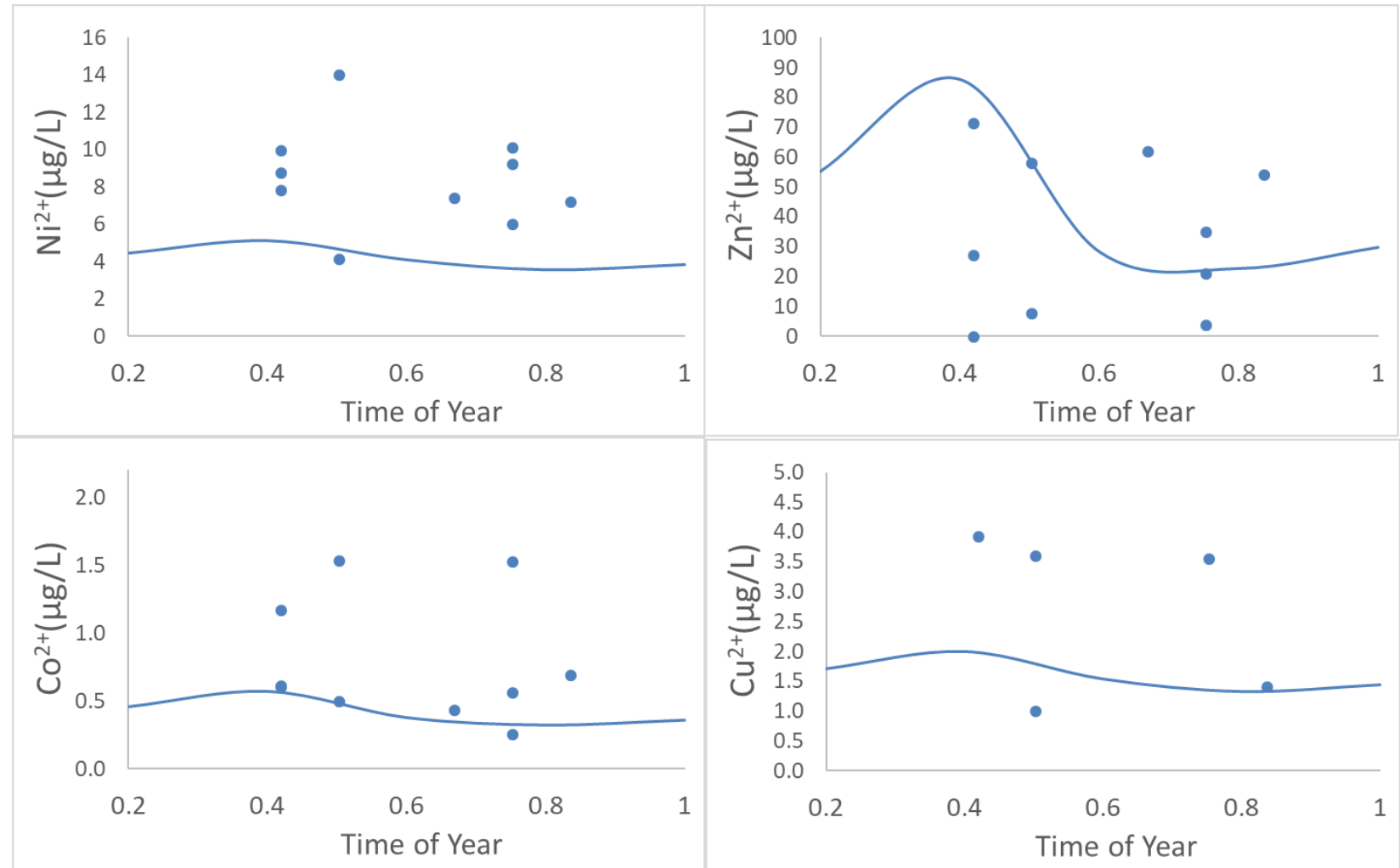

FigURE 13 - SimULATED WATER GEOCHEMISTRY VARIANCE AT 5 M FOR THE $29^{\text {TH }}$ YeAR, PLOTTED WITH TRACE METAL DATA COLLECTED AT 5 M DEPTH.

With large infiltration events there may be some flushing occurring in pore spaces that were previously dry containing some weathering products and evaporite minerals. The model seems to capture this phenomenon and may explain the variable concentrations of water samples collected at the same location since the precipitation and temperature changes fluctuate from year to year. Similarly, some fluctuations in trace metal concentrations may be due to sorption processes. Although sorption processes were not considered in the simulation, sorbed trace metals encountering a change in $\mathrm{pH}$ (either from pooling water or the water table) may be desorbed and released into the environment (Kjøller et al., 2004) leading to an increase in pore water concentration. Manganese and iron oxides are well known trace metal sinks and can be quite mobile within the water table. These oxides have large surface areas and readily sorb trace metal ions (Singh et al., 1984; Horowitz 1985: Goldberg, 1958; Krauskopf, 1956).

\subsection{Model Calibration Results}

Since there is a significant variance in the geochemistry depending on the time of year, the 29.6-year mark was chosen for calibration of the model as this time also corresponds to the time of year where a 
majority of pore water samples were collected. More emphasis was placed on data from hole 3-2 for calibration as it had a more complete data set.

\subsection{1 pH}

The model $\mathrm{pH}$ results are very similar to the trend seen in the field observations, falling within the standard deviations of hole 3-2 at all depths, and within the standard deviation of hole 3-1 at 4.2 m. The cover $\mathrm{pH}$ is approximately a $\mathrm{pH}$ of 1 higher than the rest of the waste rock pile (Figure14).

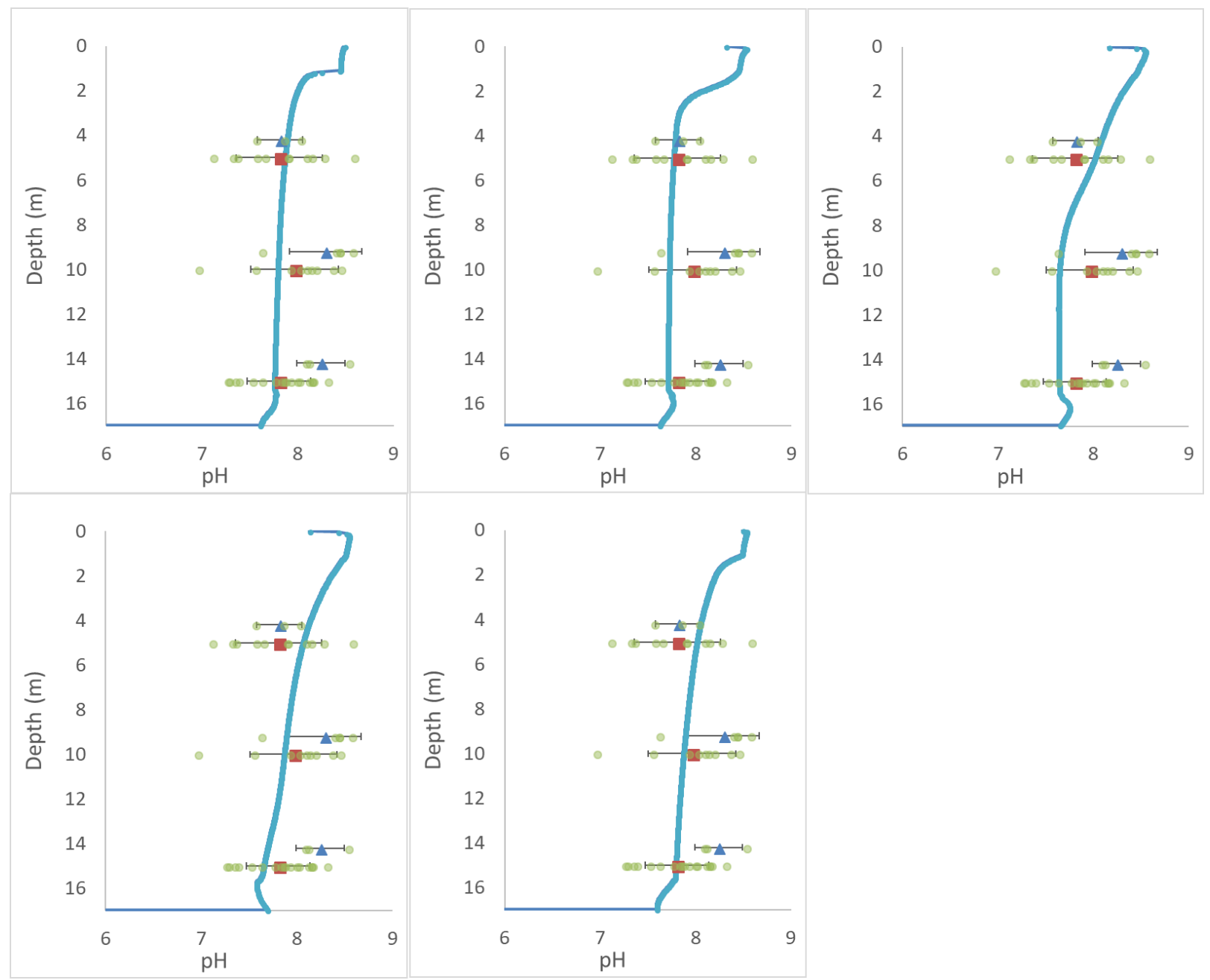

FigURE 14 - PH RESULTS FROM THE MIN3P SIMULATION (SOLID BLUE LINE) AT (FROM LEFT TO RIGHT) 29.2 YEARS, 29.4 YEARS, 29.6 YEARS, 29.8YEARS AND 30 YEARS, WITH WATER CHEMISTRY AVERAGES FOR HOLES 3-1 (BLUE TRIANGLES) AND 3-2 (RED SQUARES) WITH STANDARD DEVIATION ERROR BARS. GREEN CIRCLES ARE PORE WATER GEOCHEMISTRY DATA POINTS FOR BOTH HOLES TO SHOW DISTRIBUTION OF VALUES. 


\subsubsection{Alkalinity}

Alkalinity proved difficult to replicate, values fall short of the minimum values seen in the field data. It is unclear what is causing the lower alkalinity in the simulation. Changes in mineral dissolution rates had little effect on overall alkalinity. With an average ranging from $47 \mathrm{mg} / \mathrm{L}$ to $71 \mathrm{mg} / \mathrm{L}$, the model alkalinity is four to six times lower than values observed in the field which were typically $400-500 \mathrm{mg} / \mathrm{L}$ with some occasional outliers at $9.2 \mathrm{~m}$ exceeding $1000 \mathrm{mg} / \mathrm{L}$ (Figure 15).

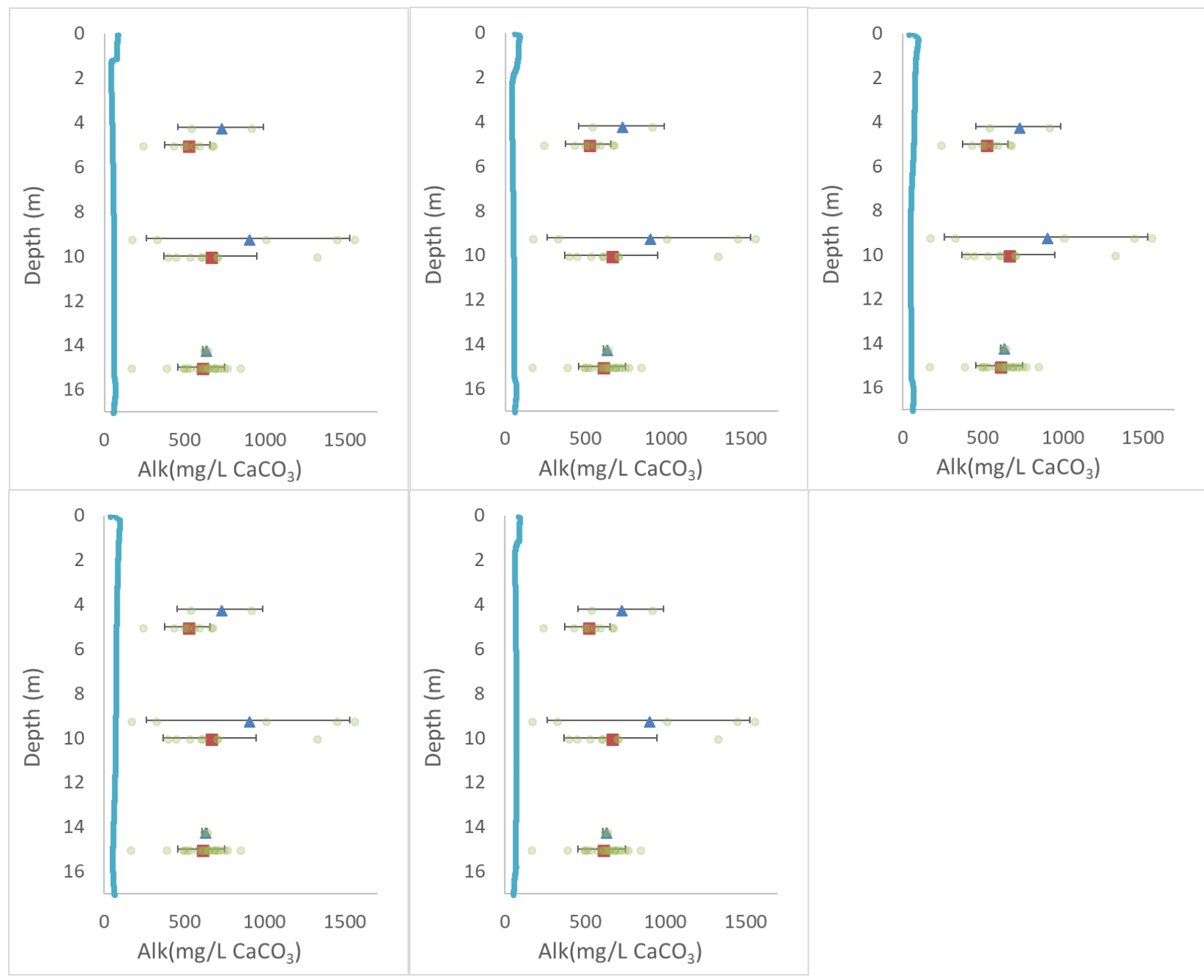

FigURE 15 - ALKALINITY RESULTS FROM THE MIN3P SIMULATION (SOLID BLUE LINE) AT (FROM LEFT TO RIGHT) 29.2 YEARS, 29.4 YEARS, 29.6 YEARS, 29.8YEARS AND 30 YEARS, WITH WATER CHEMISTRY AVERAGES FOR HOLES 3-1 (BLUE TRIANGLES) AND 3-2 (RED SQUARES) WITH STANDARD DEVIATION ERROR BARS. GREEN CIRCLES ARE PORE WATER GEOCHEMISTRY DATA POINTS FOR BOTH HOLES TO SHOW DISTRIBUTION OF VALUES. 


\subsubsection{Sulfate}

Sulfate results from the MIN3P simulation vary depending on the season but fall outside the standard deviation seen in the field data for all but the shallow $4.2 \mathrm{~m}$ and $5 \mathrm{~m}$ depths. At 29.4 years the influx of melt water can be seen as a pulse with higher levels of sulfate. At 29.6 years levels averaged $1360 \mathrm{mg} / \mathrm{L}$ with a maximum of $2429 \mathrm{mg} / \mathrm{L}$ at approximately $10 \mathrm{~m}$ and levels less than $10 \mathrm{mg} / \mathrm{L}$ in the cover. By 29.8 years the pulse is at the water table. At 30 years the model data most closely resembles that of field observations having minimum sulfate levels throughout (Figure 16). The sulfate levels do not indicate the dissolution rates of sulfides are too high, but rather that secondary minerals are likely not consuming excess sulfate in solution as indicated from the saturation indices of jarosite and gypsum.

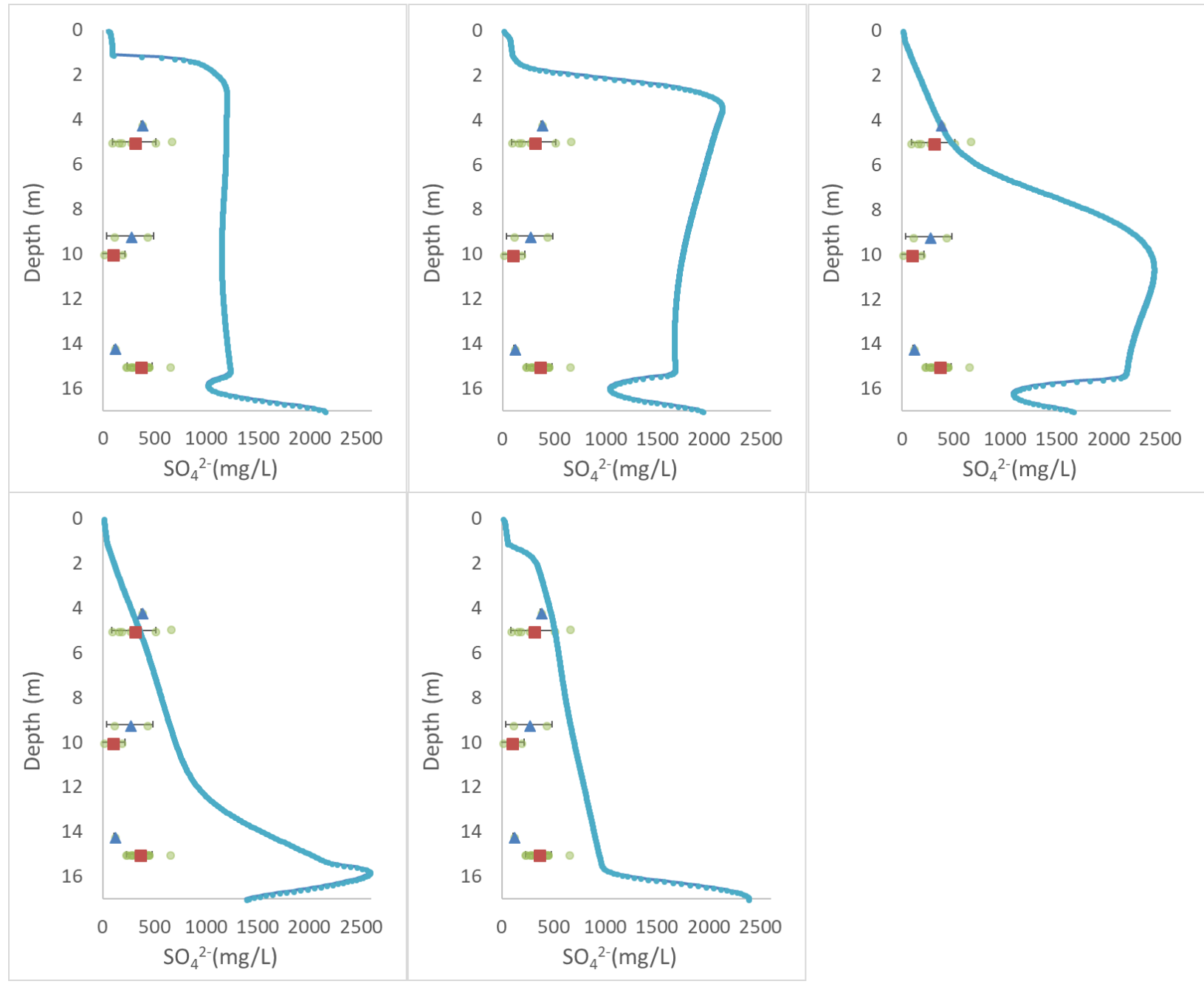

FIGURE 16 - SULFATE RESULTS FROM THE MIN3P SIMULATION (SOLID BLUE LINE) AT (FROM LEFT TO RIGHT) 29.2 YEARS, 29.4 YEARS, 29.6 YEARS, 29.8YEARS AND 30 YEARS, WITH WATER CHEMISTRY AVERAGES FOR HOLES 3-1 (BLUE TRIANGLES) AND 3-2 (RED SQUARES) WITH STANDARD DEVIATION ERROR BARS. GREEN CIRCLES ARE PORE WATER GEOCHEMISTRY DATA POINTS FOR BOTH HOLES TO SHOW DISTRIBUTION OF VALUES. 


\subsubsection{Calcium}

Similar to sulfate levels, $\mathrm{Ca}^{2+}$ levels were affected by the influx of melt and rain water. Levels fell within the standard deviation of both holes at various times over the course of the $29^{\text {th }}$ year of simulation. As with sulfate, a pulse can be seen at 29.4 years, arriving at the water table at 29.8 years (Figure 17). At 29.6 years the average $\mathrm{Ca}^{2+}$ concentration was $303 \mathrm{mg} / \mathrm{L}$ similar to that of field data, with a maximum of $523 \mathrm{mg} / \mathrm{L}$ at the pulse.
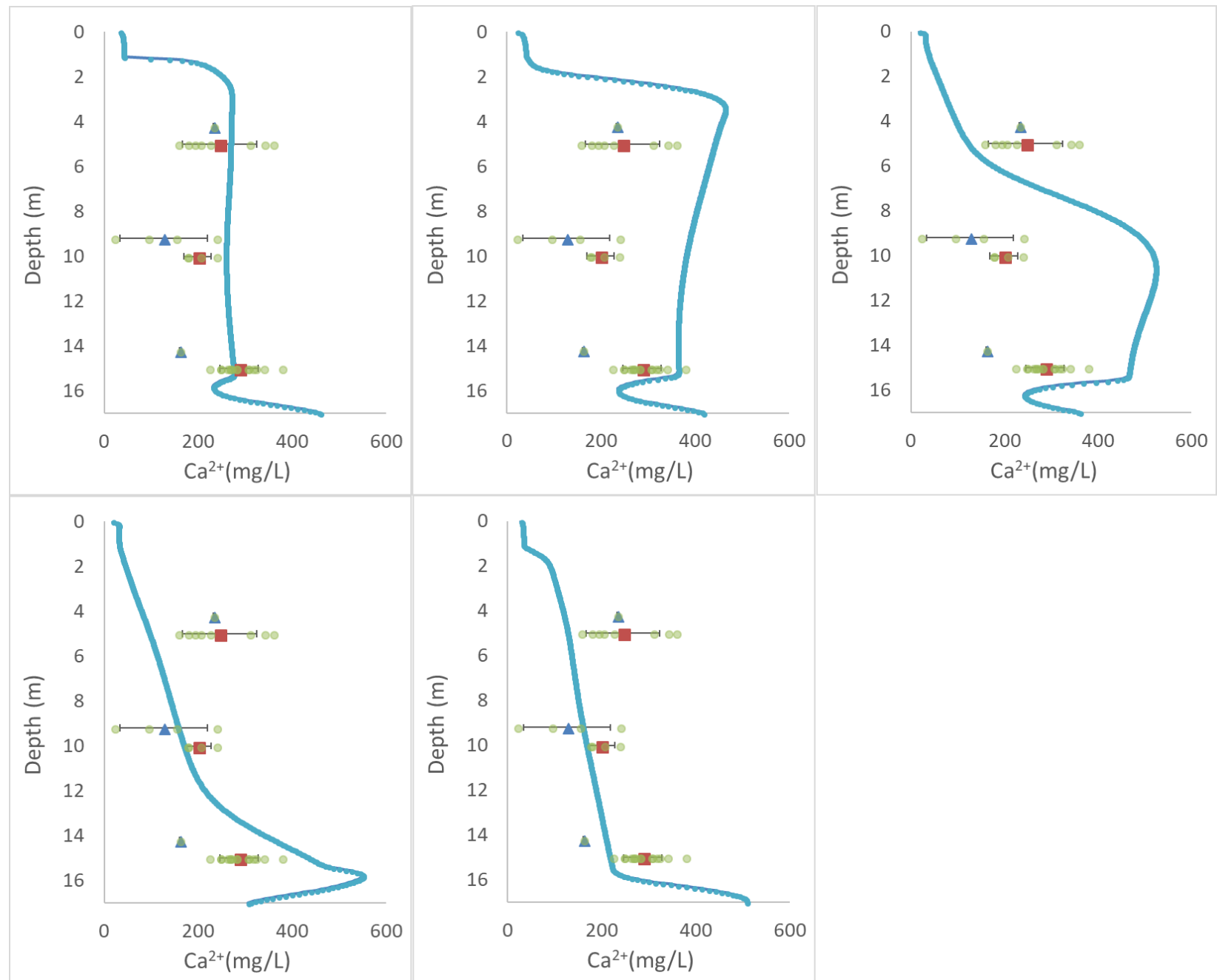

FigURE 17 - CA ${ }^{2+}$ RESULTS FROM THE MIN3P SIMULATION (SOLID BLUE LINE) AT (FROM LEFT TO RIGHT) 29.2 YEARS, 29.4 YEARS, 29.6 YEARS, 29.8YEARS AND 30 YEARS, WITH WATER CHEMISTRY AVERAGES FOR HOLES 3-1 (BLUE TRIANGLES) AND 3-2 (RED SQUARES) WITH STANDARD DEVIATION ERROR BARS. GREEN CIRCLES ARE PORE WATER GEOCHEMISTRY DATA POINTS FOR BOTH HOLES TO SHOW DISTRIBUTION OF VALUES. 


\subsubsection{Magnesium}

Magnesium levels in the simulation most closely resembled data from hole 3-1 earlier in the year. At 29.6 years the average $\mathrm{Mg}^{2+}$ concentration is $174 \mathrm{mg} / \mathrm{L}$ with a maximum of $303.9 \mathrm{mg} / \mathrm{L}$ at $\sim 10 \mathrm{~m}$ and fall within the standard deviation of hole 3-1 at $9.2 \mathrm{~m}$ and $14.2 \mathrm{~m}$ depth. Following the effects of the pulse, concentrations resemble those of hole 3-2 with an average of $90.1 \mathrm{mg} / \mathrm{L}$ throughout save for levels in the water table which had a maximum of $300 \mathrm{mg} / \mathrm{L}$ (Figure 18).
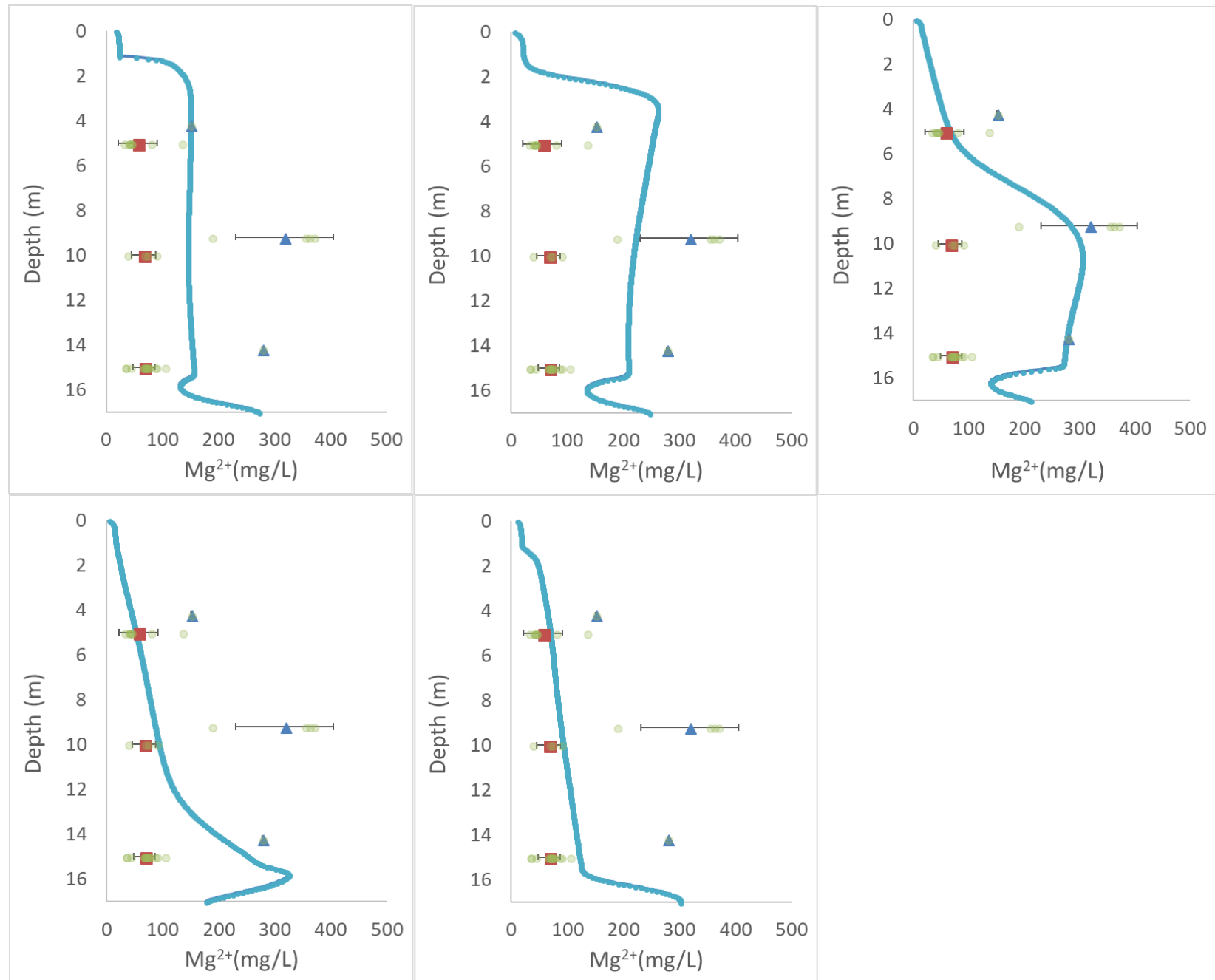

FIGURE 18 - MG $^{2+}$ RESULTS FROM THE MIN3P SIMULATION (SOLID BLUE LINE) AT (FROM LEFT TO RIGHT) 29.2 YEARS, 29.4 YEARS, 29.6 YEARS, 29.8YEARS AND 30 YEARS, WITH WATER CHEMISTRY AVERAGES FOR HOLES 3-1 (BLUE TRIANGLES) AND 3-2 (RED SQUARES) WITH STANDARD DEVIATION ERROR BARS. GREEN CIRCLES ARE PORE WATER GEOCHEMISTRY DATA POINTS FOR BOTH HOLES TO SHOW DISTRIBUTION OF VALUES. 


\subsubsection{Total Iron}

The model over-predicts iron levels with a trend of increasing concentration with depth. The iron is primarily $\mathrm{Fe}^{3+}$ with concentrations of $\mathrm{Fe}^{2+}$ at $2.6 \times 10^{-4} \mathrm{\mu g} / \mathrm{L}$ or lower until encountering the water table. Average levels of total iron at the 29.6-year mark were approximately $133.7 \mu \mathrm{g} / \mathrm{L}$ with a max of 200.6 $\mu \mathrm{g} / \mathrm{L}$. The effect of rain and melt water influx is less drastic, particularly at deeper depths as the levels do not subside with the passing of the pulse (Figure 19). The elevated concentration of total iron is most likely due to a lack of siderite precipitation in the simulation (discussed later in section 4.6.2). Given this, the model seemingly captures the iron sequestration caused by sulfide dissolution and even captures the gradual increase with depth.
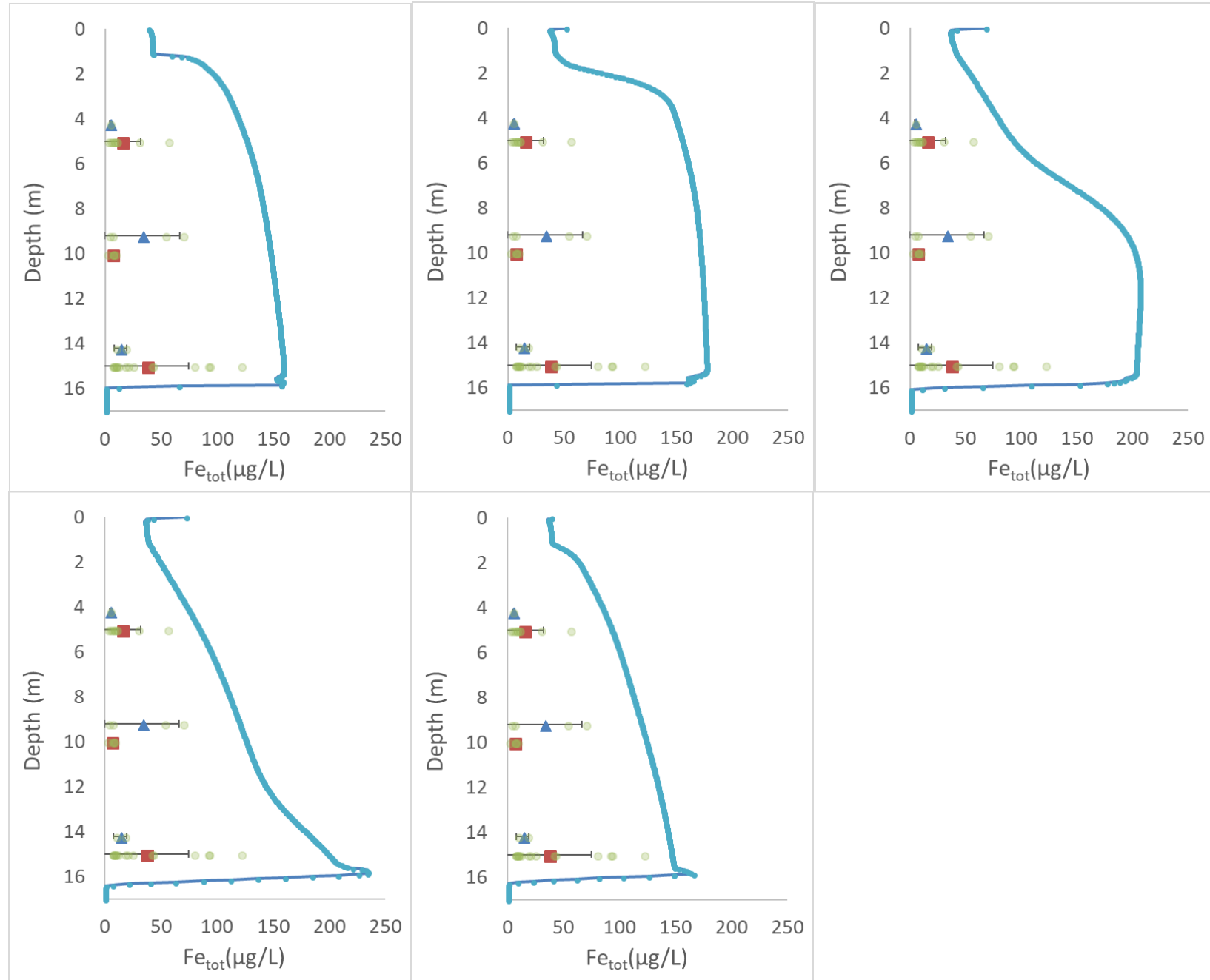

FIGURE 19 - TOTAL IRON RESULTS FROM THE MIN3P SIMULATION (SOLID BLUE LINE) AT (FROM LEFT TO RIGHT) 29.2 YEARS, 29.4 YEARS, 29.6 YEARS, 29.8YEARS AND 30 YEARS, WITH WATER CHEMISTRY AVERAGES FOR HOLES 3-1 (BLUE TRIANGLES) AND 3-2 (RED SQUARES) WITH STANDARD DEVIATION ERROR BARS. GREEN CIRCLES ARE PORE WATER GEOCHEMISTRY DATA POINTS FOR BOTH HOLES TO SHOW DISTRIBUTION OF VALUES. 


\subsubsection{Nickel}

Simulation results for $\mathrm{Ni}^{2+}$ were low at $4.2 \mathrm{~m}$ and $5 \mathrm{~m}$ being out of the standard deviation range but are close to the average values for both holes at other depths. The effect of spring rain and melt water is much more subdued but can still be observed (Figure 20). The average at 29.6 years is $4.48 \mu \mathrm{g} / \mathrm{L}$ with a maximum of $5.51 \mu \mathrm{g} / \mathrm{L}$ falling in the middle of the standard deviation for hole $3-2$ at $10 \mathrm{~m}$ and $15 \mathrm{~m}$ depth, and that of 3-1 at $9.2 \mathrm{~m}$.
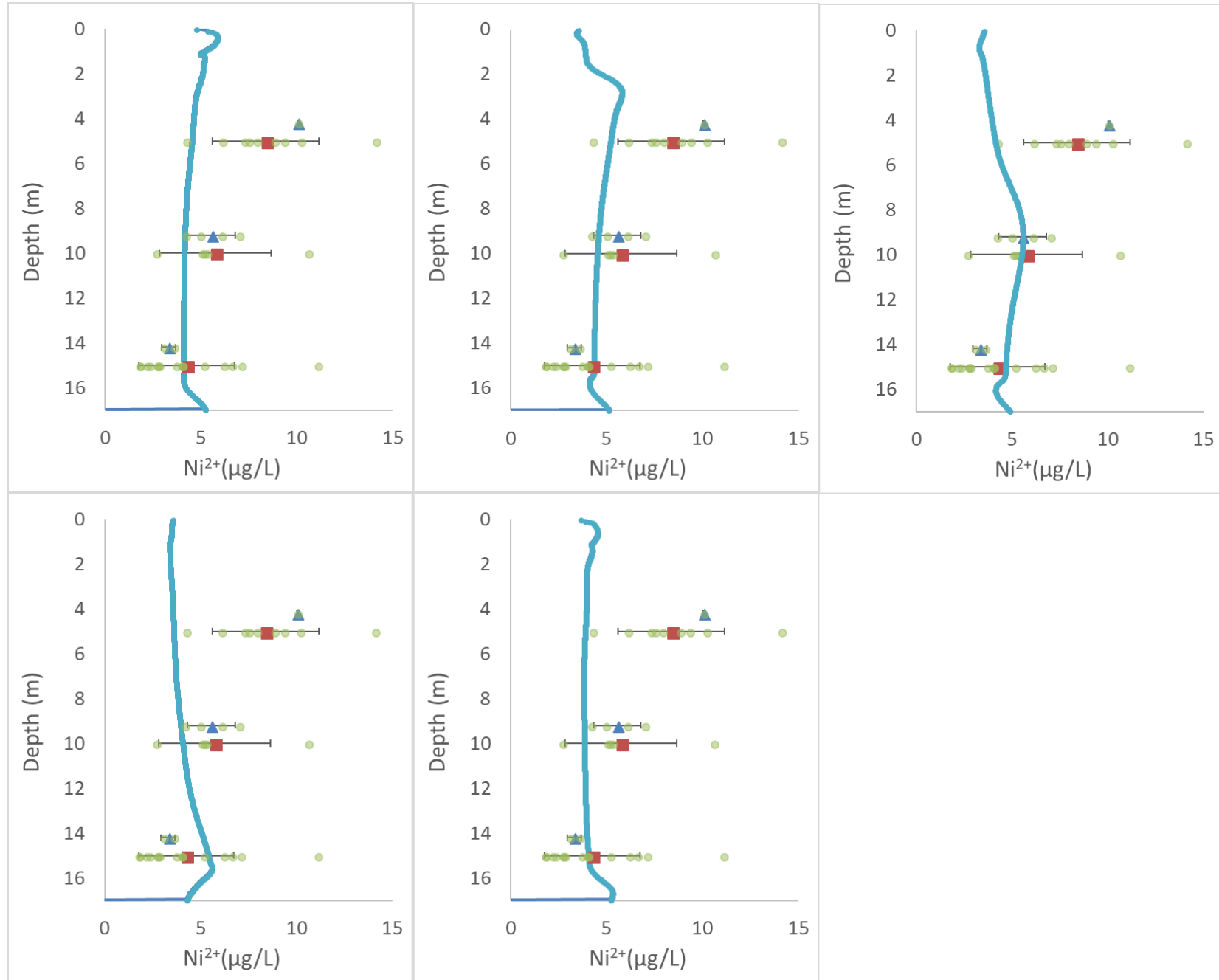

FIGURE 20 - $\mathrm{NI}^{2+}$ RESULTS FROM THE MIN3P SIMULATION (SOLID BLUE LINE) AT (FROM LEFT TO RIGHT) 29.2 YEARS, 29.4 YEARS, 29.6 YEARS, 29.8YEARS AND 30 YEARS, WITH WATER CHEMISTRY AVERAGES FOR HOLES 3-1 (BLUE TRIANGLES) AND 3-2 (RED SQUARES) WITH STANDARD DEVIATION ERROR BARS. GREEN CIRCLES ARE PORE WATER GEOCHEMISTRY DATA POINTS FOR BOTH HOLES TO SHOW DISTRIBUTION OF VALUES. 


\subsubsection{Zinc}

Zinc values for the simulation were similar to those for hole 3-2 and were within or very close to the standard deviation of that hole throughout the column. At the 29.6 year-mark, the average $\mathrm{Zn}^{2+}$ concentration was $5.65 \mu \mathrm{g} / \mathrm{L}$ with a maximum of $9.87 \mu \mathrm{g} / \mathrm{L}$. Hole 3-1 has several outliers skewing its average value data points, however there are a few data points in close proximity to the simulation trend. As with $\mathrm{Ni}^{2+}$ the effect of spring rain and melt water influx can be seen but it much subtler Figure 21).

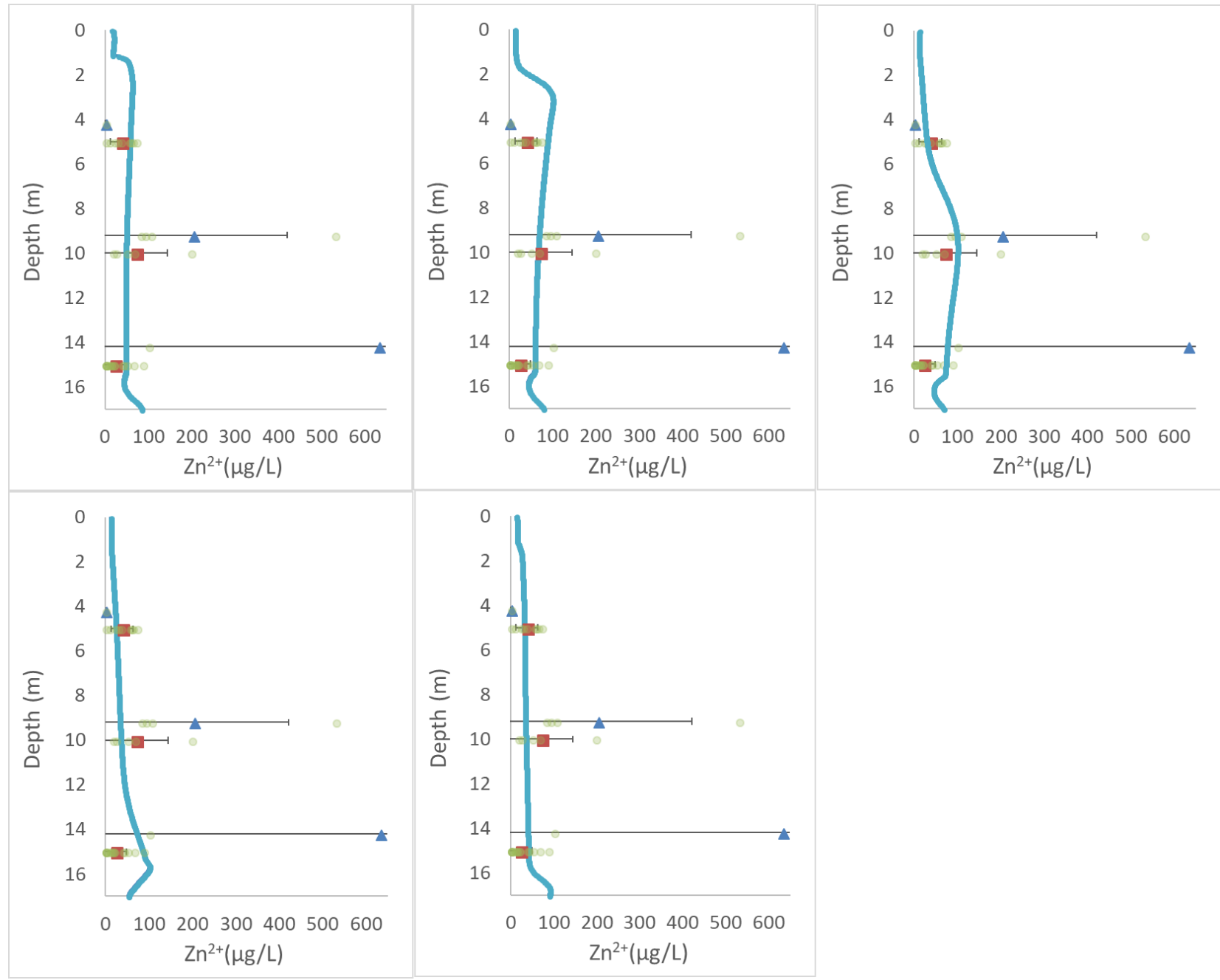

FIGURE 21 - ZN ${ }^{2+}$ RESULTS FROM THE MIN3P SIMULATION (SOLID BLUE LINE) AT (FROM LEFT TO RIGHT) 29.2 YEARS, 29.4 YEARS, 29.6 YEARS, 29.8YEARS AND 30 YEARS, WITH WATER CHEMISTRY AVERAGES FOR HOLES 3-1 (BLUE TRIANGLES) AND 3-2 (RED SQUARES) WITH STANDARD DEVIATION ERROR BARS. GREEN CIRCLES ARE PORE WATER GEOCHEMISTRY DATA POINTS FOR BOTH HOLES TO SHOW DISTRIBUTION OF VALUES. 


\subsubsection{Cobalt}

Cobalt values from the simulation are approximately within $1 \mu \mathrm{g} / \mathrm{L}$ of all values attained in field observations. The values are within the standard deviation of hole 3-2 and slightly lower than those of hole 3-1. Concentrations for hole 3-1 are above $1 \mu \mathrm{g} / \mathrm{L}$ with a maximum of $1.77 \mu \mathrm{g} / \mathrm{L}$. The average $\mathrm{CO}^{2+}$ concentration at 29.6 years is $0.46 \mu \mathrm{g} / \mathrm{L}$ and the maximum is $0.62 \mu \mathrm{g} / \mathrm{L}$ (Figure 22).
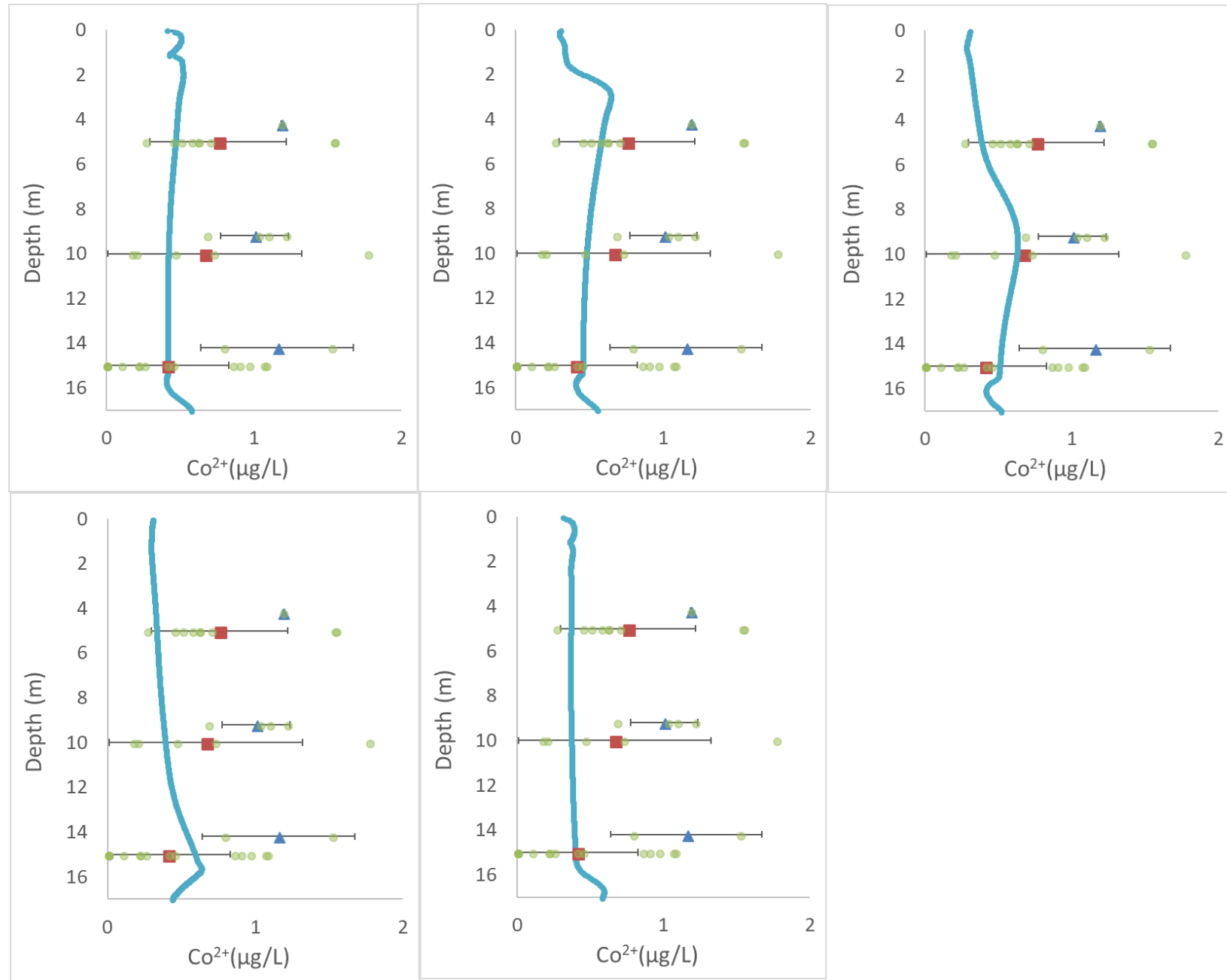

FIGURE 22 - C0 ${ }^{2+}$ RESULTS FROM THE MIN3P SIMULATION (SOLID BLUE LINE) AT (FROM LEFT TO RIGHT) 29.2 YEARS, 29.4 YEARS, 29.6 YEARS, 29.8YEARS AND 30 YEARS, WITH WATER CHEMISTRY AVERAGES FOR HOLES 3-1 (BLUE TRIANGLES) AND 3-2 (RED SQUARES) WITH STANDARD DEVIATION ERROR BARS. GREEN CIRCLES ARE PORE WATER GEOCHEMISTRY DATA POINTS FOR BOTH HOLES TO SHOW DISTRIBUTION OF VALUES.

\subsubsection{Copper}

Simulation results for $\mathrm{Cu}^{2+}$ were slightly underpredicted with concentrations within the lower limits of the standard deviation of hole 3-2. This discrepancy is likely because the mineral dissolution rate for chalcopyrite was too low. Because of this, concentration changes were too low to observe seasonal 
variations. The average concentration for hole 3-1 was $4.21 \mu \mathrm{g} / \mathrm{L}$ save for one outlier with $149.9 \mu \mathrm{g} / \mathrm{L}$, whereas the average concentration at hole $3-2$ was $6.25 \mu \mathrm{g} / \mathrm{L}$ with a maximum outlier at $33.85 \mu \mathrm{g} / \mathrm{L}$. In contrast, at 29.6 years the average concentration was $1.73 \mu \mathrm{g} / \mathrm{L}$ with a maximum of $2.5 \mu \mathrm{g} / \mathrm{L}$ (Figure 23).
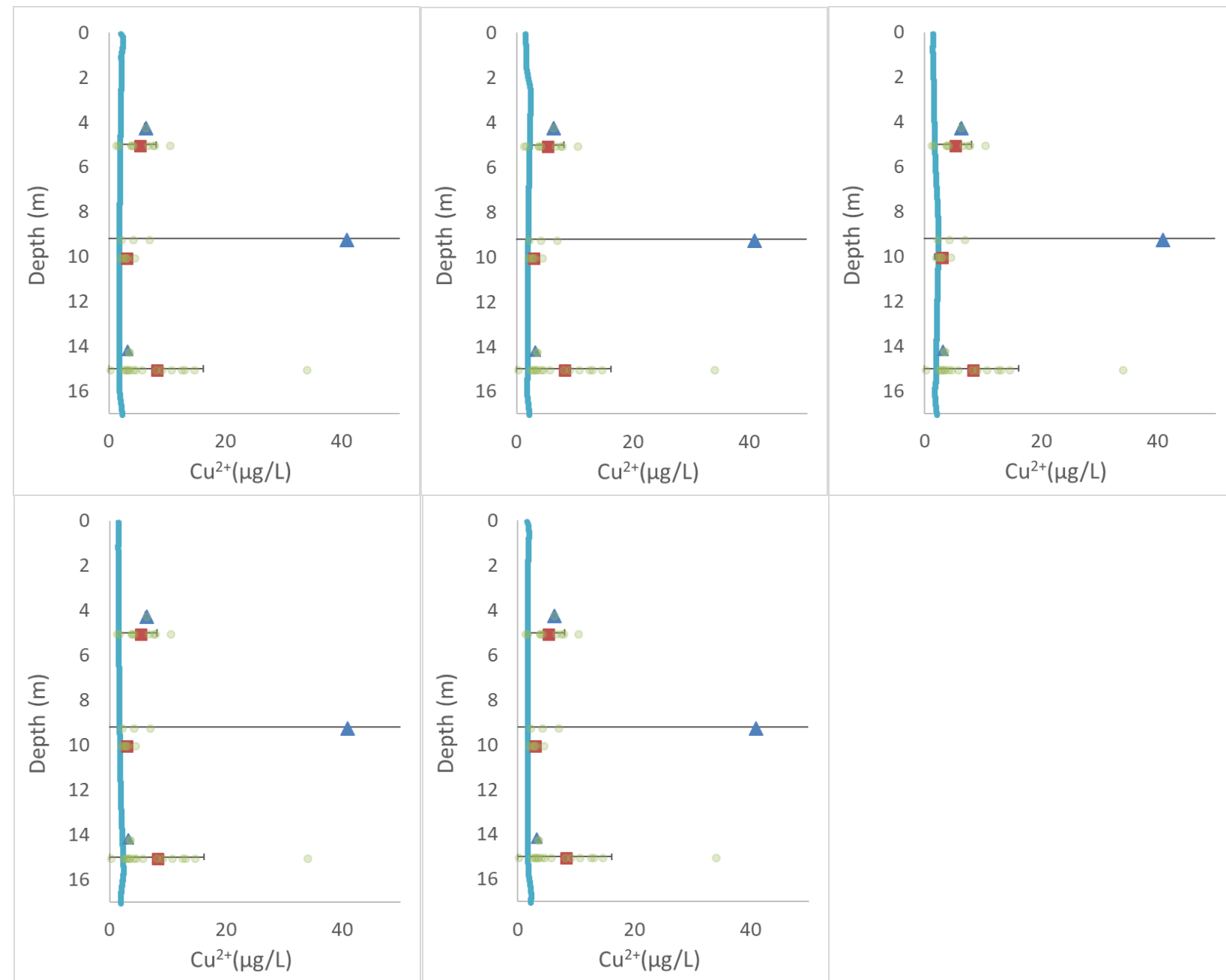

FigURE 23 - CU $^{2+}$ RESULTS FROM THE MIN3P SIMULATION (SOLID BLUE LINE) AT (FROM LEFT TO RIGHT) 29.2 YEARS, 29.4 YEARS, 29.6 YEARS, 29.8YEARS AND 30 YEARS, WITH WATER CHEMISTRY AVERAGES FOR HOLES 3-1 (BLUE TRIANGLES) AND 3-2 (RED SQUARES) WITH STANDARD DEVIATION ERROR BARS. GREEN CIRCLES ARE PORE WATER GEOCHEMISTRY DATA POINTS FOR BOTH HOLES TO SHOW DISTRIBUTION OF VALUES.

\subsection{Mineral Dissolution and Precipitation}

\subsubsection{Geochemical Evolution}

While only minor changes occurred from year to year, the model demonstrates a gradual decrease in the production of sulfate and total iron, and a gradual increase in $\mathrm{pH}$ over time (Figure 24). The gradual rise in $\mathrm{pH}$ and alkalinity indicates carbonate minerals are continuing to buffer acidity. The decrease in 
sulfate and total iron production over the course of the simulation are attributed to the decrease in reaction rate due to the weathering of sulfide minerals, and by extension a reduction in their reactive surface areas; a result consistent with the Shrinking Core Model (Figure 24). Sulfate levels remain 2 to 4 four times higher than target averages from holes 3-1 and 3-2. The excess sulfate may be related to the low precipitation of sulfate minerals discussed below in section 4.6.2. The total iron comprised of mostly ferric iron are an average 3 times higher than target levels seen in the sampling data. The $\mathrm{pH}$ results after 30 years were very close with only two outliers from hole 3-1 with a pH of 0.4 higher than the model. Alkalinity remained low averaging $50-60 \mathrm{mg} / \mathrm{L}$. These levels are much lower than those of the sample data which often exceeded $500 \mathrm{mg} / \mathrm{L}$.
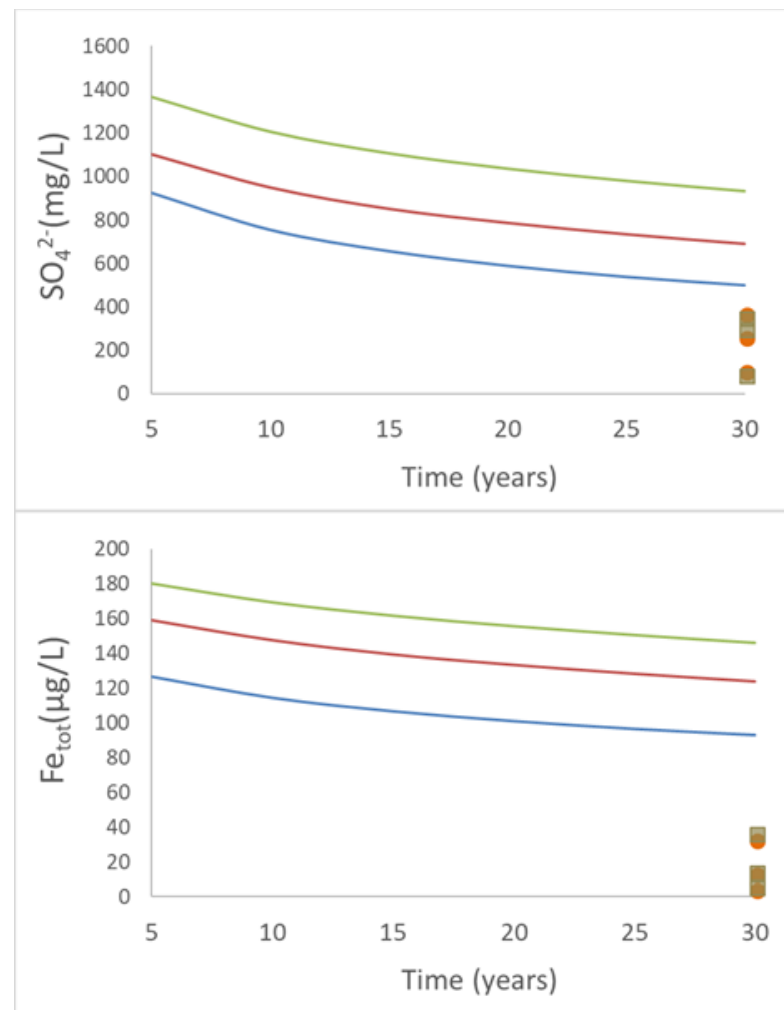
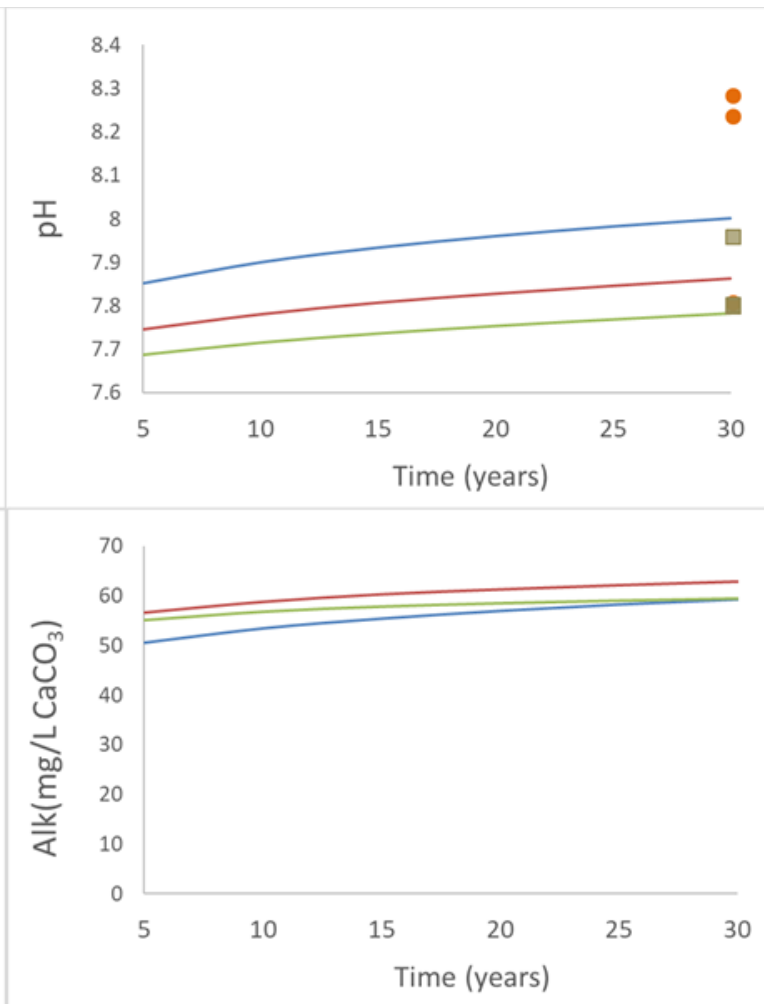

Figure 24 - MOdel outPUt EVERY 5 YeARS FOR JANUARY $1^{\text {ST }}$ AT 5 M (BLUE) DEPTH, 10 M (RED) DEPTH AND 15 M DEPTH (GREEN) OVER THE 30 YEAR SIMULATION WITH DEPTH AVERAGES FOR HOLE 3-1 (ORANGE CIRCLES) AND HOLE 3-2 (BRONZE SQUARES) AT $5 \mathrm{M}, 10 \mathrm{M}$ AND $15 \mathrm{M}$. TREND LINES SHOW GENERAL DECREASE OF TOTAL IRON AND SULFATE AND INCREASE OF PH AND ALKALINITY OVER THE 30 YEAR SIMULATION.

The oxygen and ferric iron pathways are described separately to show how they each contributed to mineral dissolution. However, the total mineral dissolution is a sum of the two as they represent the same mineral particle. Mineral dissolution of sulfides was greatest at the top of the column (Table 6). 
Beginning with the oxygen dissolution pathway at $1.12 \mathrm{~m}$, primary sulfides pyrrhotite and pyrite were reduced by approximately $6.6 \%$ and $5.21 \%$ respectively. Sphalerite was reduced by $0.05 \%$ while pentlandite and chalcopyrite had very minor amounts dissolving. At $9 \mathrm{~m}$, pyrrhotite and pyrite were reduced by $3.62 \%$ and $2.78 \%$ respectively, while sphalerite was reduced by $0.02 \%$, and pentlandite and chalcopyrite were reduced by less than a fraction of a percent. Although the volume fractions of sphalerite, pentlandite and chalcopyrite remain at over $99 \%$, trace metal concentrations indicate sufficient amounts are dissolving. The comparatively low dissolution rates are attributed to low diffusion rates set through the calibration of trace metal concentrations. Volume fraction changes at $17 \mathrm{~m}$ remained unchanged for all sulfides. Volume fraction reductions in the ferric iron pathway were only relevant to pyrrhotite, reducing by $0.01 \%$ at both $1.12 \mathrm{~m}$ and $9 \mathrm{~m}$ indicating the oxidative pathway is the primary means of dissolution.

TABLE 6 -INITIAL AND POST SIMULATION VOLUME FRACTIONS OF SULFIDE MINERALS FOR BOTH OXYGEN AND FERRIC IRON PATHWAYS

\begin{tabular}{ccccccc}
\hline Mineral & Depth $(\mathrm{m})$ & Initial Vol. & $\begin{array}{c}\text { O2 Path } \\
\text { Vol. }\end{array}$ & $\begin{array}{c}\text { Fe Path } \\
\text { Vol. }\end{array}$ & $\begin{array}{c}\text { Remaining Vol. } \\
\text { O2 Path (\%) }\end{array}$ & $\begin{array}{c}\text { Remaining Vol. } \\
\text { Fe Path (\%) }\end{array}$ \\
\hline Pyrrhotite & 1.12 & $3.27 \times 10^{-3}$ & $3.05 \times 10^{-3}$ & $3.27 \times 10^{-3}$ & 93.41 & 99.99 \\
& 9 & $3.27 \times 10^{-3}$ & $3.15 \times 10^{-3}$ & $3.27 \times 10^{-3}$ & 96.38 & 99.99 \\
& 17 & $3.27 \times 10^{-3}$ & $3.27 \times 10^{-3}$ & $3.27 \times 10^{-3}$ & 100.00 & 100.00 \\
\hline Pyrite & 1.12 & $1.46 \times 10^{-3}$ & $1.39 \times 10^{-3}$ & $1.46 \times 10^{-3}$ & 94.79 & 100.00 \\
& 9 & $1.46 \times 10^{-3}$ & $1.42 \times 10^{-3}$ & $1.46 \times 10^{-3}$ & 97.22 & 100.00 \\
& 17 & $1.46 \times 10^{-3}$ & $1.46 \times 10^{-3}$ & $1.46 \times 10^{-3}$ & 100.00 & 100.00 \\
\hline Pentlandite & 1.12 & $6.48 \times 10^{-5}$ & $6.48 \times 10^{-5}$ & $6.48 \times 10^{-5}$ & 100.00 & 100.00 \\
& 9 & $6.48 \times 10^{-5}$ & $6.48 \times 10^{-5}$ & $6.48 \times 10^{-5}$ & 100.00 & 100.00 \\
& 17 & $6.48 \times 10^{-5}$ & $6.48 \times 10^{-5}$ & $6.48 \times 10^{-5}$ & 100.00 & 100.00 \\
\hline Sphalerite & 1.12 & $3.43 \times 10^{-5}$ & $3.42 \times 10^{-5}$ & $3.43 \times 10^{-5}$ & 99.95 & 100.00 \\
& 9 & $3.43 \times 10^{-5}$ & $3.43 \times 10^{-5}$ & $3.43 \times 10^{-5}$ & 99.98 & 100.00 \\
& 17 & $3.43 \times 10^{-5}$ & $3.43 \times 10^{-5}$ & $3.43 \times 10^{-5}$ & 100.00 & 100.00 \\
\hline Chalcopyrite & 1.12 & $1.54 \times 10^{-5}$ & $1.54 \times 10^{-5}$ & $1.54 \times 10^{-5}$ & 100.00 & 100.00 \\
& 9 & $1.54 \times 10^{-5}$ & $1.54 \times 10^{-5}$ & $1.54 \times 10^{-5}$ & 100.00 & 100.00 \\
& 17 & $1.54 \times 10^{-5}$ & $1.54 \times 10^{-5}$ & $1.54 \times 10^{-5}$ & 100.00 & 100.00 \\
\hline
\end{tabular}

Carbonate dissolution occurred primarily at the top of the column. Calcite was reduced by $0.12 \%$ at 1.12 $\mathrm{m}$, was unchanged at $9 \mathrm{~m}$ and precipitated at $17 \mathrm{~m}$ increasing in volume fraction by $0.06 \%$. Dolomite was the primary buffering mineral with volume fractions being reduced by $0.95 \%, 0.7 \%$ and $0.04 \%$ at $1.12 \mathrm{~m}, 9 \mathrm{~m}$, and $17 \mathrm{~m}$, respectively. The volume fraction of secondary minerals gypsum, jarosite and siderite remain unchanged throughout the simulation, as did those for anorthite and albite. Ferrihydrite 
volume fractions significantly increased by several orders of magnitude at $1.12 \mathrm{~m}$ and $9 \mathrm{~m}$, indicating it was precipitating. Its volume fractions remained unchanged at $17 \mathrm{~m}$.

TABLE 7- INITIAL AND FINAL VOLUME FRACTIONS FOR CALCITE, DOLOMITE AND FERRIHYDRITE.

\begin{tabular}{ccccc}
\hline & Depth $(\mathrm{m})$ & Initial $\mathbf{\phi i}$ & Final $\mathbf{\phi i}$ & Remaining $\mathbf{\phi i}(\%)$ \\
\hline Calcite & 1.12 & $3.50 \times 10^{-2}$ & $3.50 \times 10^{-2}$ & 99.88 \\
& 9 & $3.50 \times 10^{-2}$ & $3.50 \times 10^{-2}$ & 100.00 \\
& 17 & $3.50 \times 10^{-2}$ & $3.50 \times 10^{-2}$ & 100.06 \\
\hline Dolomite & 1.12 & $4.40 \times 10^{-2}$ & $4.36 \times 10^{-2}$ & 99.05 \\
& 9 & $4.40 \times 10^{-2}$ & $4.37 \times 10^{-2}$ & 99.30 \\
& 17 & $4.40 \times 10^{-2}$ & $4.40 \times 10^{-2}$ & 99.96 \\
\hline Ferrihydrite & 1.12 & $1.00 \times 10^{-10}$ & $3.07 \times 10^{-4}$ & $3.07 \times 10^{8}$ \\
& 9 & $1.00 \times 10^{-10}$ & $1.66 \times 10^{-4}$ & $1.66 \times 10^{8}$ \\
& 17 & $1.00 \times 10^{-10}$ & $1.00 \times 10^{-10}$ & 100.00 \\
\hline
\end{tabular}

\subsubsection{Saturation Index}

A selection of 21 samples from field data were chosen for analysis in PHREEQC to determine the saturation indices of (SI) of calcite, dolomite, gypsum, jarosite and siderite. These samples were chosen because of the completeness of their geochemical data. The model saturation indices (SI) for calcite, dolomite, gypsum, jarosite and siderite were the plotted alongside the PHREEQC results for comparison (Figure 25). The PHREEQC SI for calcite indicates it is slightly above saturation at just under an SI of 1. The PHREEQC SI for dolomite is more saturated with values primarily ranging from 0.6 to 1.9 . In contrast the model demonstrates an SI of approximately 0 for both calcite and dolomite (Figure 25).

The model SI for gypsum is undersaturated with an SI of -4.5 at the top of the column, decreasing to approximately -8 at $17 \mathrm{~m}$. The PHREEQC results for gypsum are significantly higher with SI values ranging from -1.8 to -0.4 . The model SI values for jarosite range from -7.92 to -5.62 in the cover. The SI values decrease with depth following the cover to -38.3 at $17 \mathrm{~m}$. The PHREEQC results are variable and range from an SI of -1.56 to -6.7 . Within the cover, the model shows a siderite SI of approximately -2.5 , however, it decreases significantly in the waste rock portion from an SI of -8.1 to -9.7. In contrast the PHREEQC results range from $\mathrm{SI}-2.07$ to -3.48 (Figure 25 ).

The under-saturation of jarosite and especially gypsum is attributed to the low levels of alkalinity and explains the excess sulfate in the model simulations. The low SI of siderite in the model is attributed to little ferrous iron remaining in the pore water for this mineral to precipitate out. 


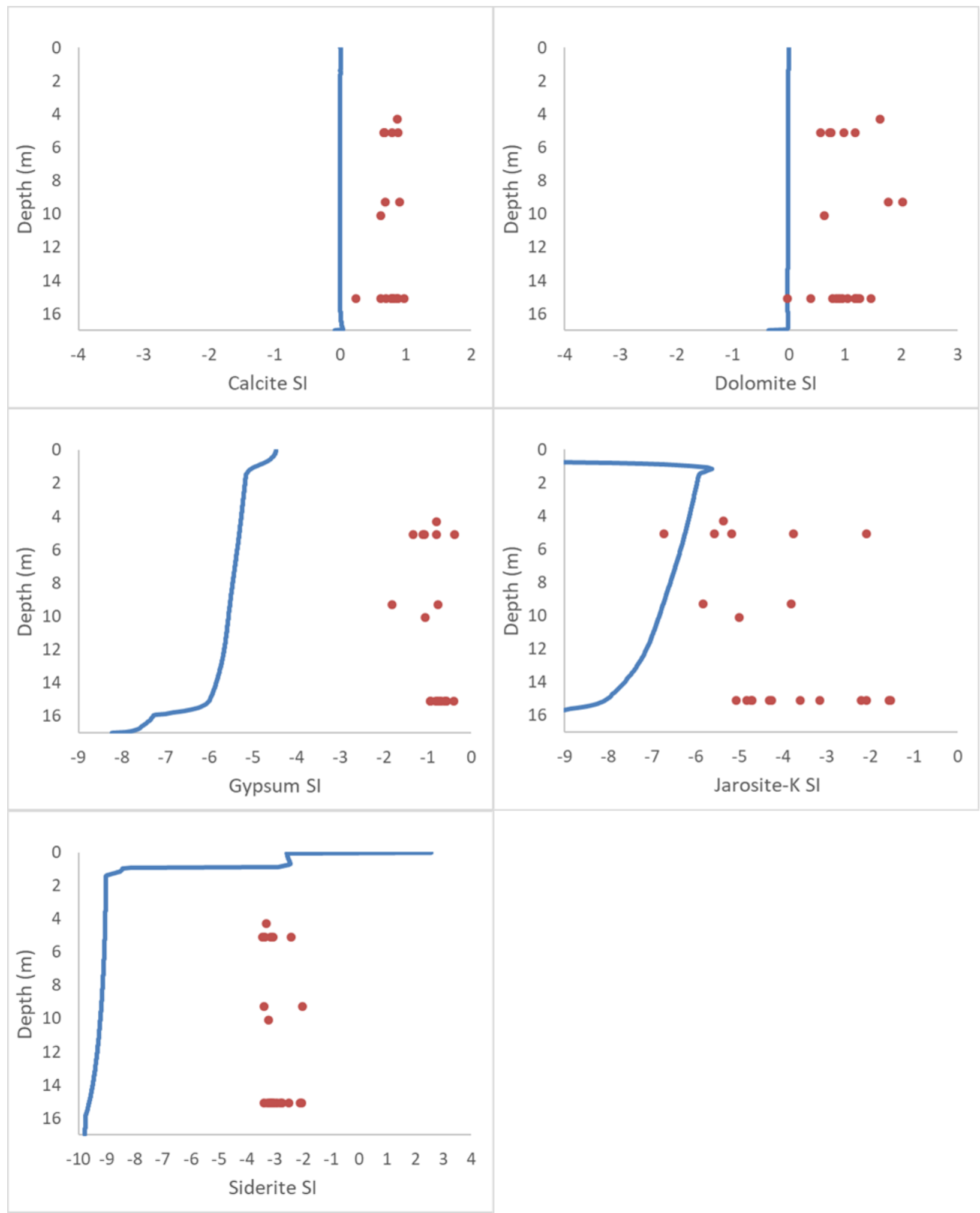

FIGURE 25 - COMPARISON OF MODEL SATURATION INDICES (BLUE LINE) WITH RESULTS FROM PHREEQC WATER DATA ANALYSIS (RED CIRCLES) PLOTTED WITH DEPTH 


\section{Chapter 5: Conclusion}

\subsection{Summary}

This project attempted to reproduce the effluent discharged by a covered historic waste rock pile at the Detour Gold mine from a theoretical fresh waste rock pile. One of the primary objectives of the project was to examine the geochemical evolution of the waste rock over the course of a 30-year simulation. The MIN3P model implemented hydrological and mineralogical characteristics of similar waste rock piles on site, along with precipitation and irradiance data from a nearby weather station in Kapuskasing, Ontario, to simulate 30 years of exposure to atmospheric conditions. The model also served to examine the effects of a non-reactive cover to reduce oxygen diffusion into the waste rock.

The conclusions of the modeling project are as follows:

1. The model had difficulty replicating the oxygen gas concentrations above $10 \mathrm{~m}$. While atmospheric levels of oxygen were observed at all depths in the field data, average levels were less than the oxygen levels produced in the simulation. It is unclear if this is a result of the chosen gas diffusion coefficient, or due to an oversimplification of the gas transport in the system. For example, advection was not modeled, and the same gas diffusion coefficient was set for both the cover and the waste rock portions. Carbon dioxide levels were similar to average values observed in the field data. Given this and that sulfide dissolution at shallow depths is generating ample iron and sulfate, the cover material in the simulation does not seem to act as a barrier to the passive influx of oxygen.

2. The model shows gradual decreases in sulfate and total iron production accompanied by gradual increases in $\mathrm{pH}$ and alkalinity over time as a result of the Shrinking Core Model. Dolomite was the main buffering mineral, with small amounts of calcite precipitating at the bottom of the column. Both calcite and dolomite had less than $1 \%$ of their mineral volume fractions reduced. Their saturation indices were close to zero. This bodes well for long term buffering capacity of the system and acid mine drainage does not seem to be an issue in the foreseeable future.

3. The model had difficulty in replicating the alkalinity observed in the field data. The elevated levels of sulfate in the model are likely related to the low saturation indices of gypsum and jarosite found with the PHREEQC analysis, indicating little precipitation is occurring to remove sulfate from the pore water.

4. The model captures the onset of seasonal variations brought about by the change in monthly infiltration rates. Periods of increased infiltration were observed as a pulse of increased 
concentration gradually moving through the column, while periods of low infiltration had concentrations gradually decrease to minimum levels. This variance along with that of real precipitation and temperature changes from one year to the next can explain the variation seen in the pore water sample data. Namely, it explains how the concentrations can be so different at a sampling location even if it is sampled at the same time from one year to the next. This result suggests long term management of waste rock piles should include a measure to limit the infiltration of water into the pile.

5. Apart from the alkalinity, sulfate and total iron, the effluent discharged from the simulated waste rock pile does resemble that of hole 3-2, more so than hole 3-1. This was expected since more emphasis was placed on matching the concentrations seen in 3-2. The $\mathrm{pH}$ and trace metals fall within the averages of pore water data collected as do $\mathrm{Ca}^{2+}$ and $\mathrm{Mg}^{2+}$ concentrations.

6. The model indicates the oxidative pathway is the primary pathway for sulfide dissolution. This is not surprising given the $\mathrm{pH}$ of the pore water. Pyrrhotite mineral volume fractions were reduced by up to $6.6 \%$ at $1.12 \mathrm{~m}$, whereas pyrite was reduced by up to $5.21 \%$, and sphalerite by up to $0.05 \%$ at the same depth. Pentlandite and chalcopyrite were relatively unchanged however trace metal results indicate their concentrations are affected by flushing events and therefore must be dissolving.

\subsection{Recommendations for Future Research}

Although there were some difficulties with some aspects of the reactive transport model, it nevertheless was able to replicate much of the pore water geochemistry from hole 3-2, even with a limited data set. Many of the shortcomings encountered can be addressed onsite or on future projects to produce a more robust model. Recommendations for such work is provided below:

1. A more detailed sampling profile is necessary to properly characterize a waste rock pile. The sampling intervals should be much smaller and be located at several locations in order to maximize data collected in the subsurface as waste rock piles are quite heterogeneous by nature. If possible, a more rigid sampling regiment should be implemented to capture trends based on season variation.

2. Tracer testing at several locations on the waste rock pile would provide more accurate residence times in which to calibrate the hydrological parameters. In addition to providing residence times, the tracers can be used to locate different flow mechanism that may occur, such as areas 
of pooling and preferred pathways during large infiltration events, and movement of groundwater into and out of lower portions of the waste rock pile.

3. The disparity between the $\mathrm{Co}^{2+}$ and $\mathrm{Ni}^{2}$ content and the volume fraction of pentlandite in the model highlights the benefit of a detailed mineralogical analysis. Although whole rock analysis did provide a basis for mineralogical data, it alone cannot discern the distribution of sulfide content and metal oxides into their respective minerals. Many trace metals may be locked up in minerals that are not represented by sulfides.

4. Although the gas profile is similar to that of the field observations, the adjustment of the gas diffusion coefficient must be done with caution as it affects diffusion in the reactive transport. Further development of the MIN3P software may eventually incorporate advective transport as well as individual gas diffusion coefficients for specific species.

5. Collection of rainwater will help to characterize the input water used in the simulation. In addition, shallow water sampling may be able to discern what percentage of ions are concentrated in infiltrating water due to evapotranspiration. 


\section{References}

Aachib, M., Mbonimpa, M., Aubertine, M.. (2004). Measurement and prediction of the oxygen diffusion coefficient in the unsaturated media, with applications to soil covers. Water, Air, Soil Pollution. Vol. 156, pp. 163-193.

Allison, J.D., Brown, D.S., Novo-Gradac, K.J.. (1991). MINTEQA2/PRODEFA2, a geochemical assessment model for environmental systems, version 3.0 User's Manual. USEPA, Athens, GO, 115p.

Allen, R.G., L.S.Pereira, D. Raes, and M. Smith. (1998). Crop evapotranspiration: guidelines for computing crop water requirements. Irrigation and Drainage Paper No. 56, Food and Agriculture Organization of the United Nations, Rome, Italy.

Belzile, Nelson, Chen Yu-Wei, Cai, Mei-Fang, Li, Yuerong. (2004). A review of pyrrhotite oxidation. Journal of Geochemical Exploration. Vol. 84, pp. 65-76.

Blum, Alex E., Stillings, Lisa, L.. (1995). Feldspar dissolution kinetics. Reviews in Mineralogy and Geochemistry. Vol. 31, pp. 315-318.

Blowes, David W., Ptacek, Carol J., Frind, Emil O., Johnson, Raymond H., Robertson, William D., Molson, John W.. (1994). Acid-Neutralization Reaction in Inactive Mine Tailings Impoundments and their Effect on the Transport of Dissolved Metals. Proceedings America Society of Mining and Reclamation. pp. 429-438.

Brookfield, A. E., Blowes, D. W., Mayer, K.U. (2006). Integration of field measurements and reactive transport modelling to evaluate contaminant transport at a sulfide mine tailings impoundment. Journal of Contaminant Hydrology. Vol. 88, pp. 1-22.

Cash, Aileen. (2014). Structural and Hydrologic Characterization of Two Historic Waste Rock Piles. M.Sc. Project, University of Alberta, Edmonton, Alberta, Canada.

Chou, Lei, Garrels, Robert M. Wollast, Roland. (1989). Comparative study of the kinetics and mechanisms of dissolution of carbonate minerals. Chemical Geology. Vol. 78. Issue 3-4, pp. 269282

Coumans, Catherine. (2003). Mining in Canada: The Bigger Picture. MiningWatch Canada Presentation for Philippine Delegation to Ottawa, Canada-October 29, 2003. Retrieved from: <https://miningwatch.ca/sites/default/files/Brief for Philippines.pdf $>$

Davis, G. B., Ritchie, A. I M.. (1986). A model of oxidation in pyritic mine Wastes: part 1 equations and approximate solution. Applied Mathematical Modelling. Vol. 10, Issue 5, pp. 314- 322.

Dionne, Yvan. (2014). Oldest Mines in the World: A Casual Survey. Retrieved from: <https://www.promine.com/blog/5-oldest-mines-in-the-world-a-casual-survey $>$

Dingman, S. L.,. (2002). Physical Hydrology, $2^{\text {nd }}$ Edition, Prentice Hall, Upper Saddle River, 2002. 
Demers, I., Molson, J., Bussière, B., Laflamme, D.. (2013). Numerical modeling of contaminated neutral drainage from a waste-rock field test cell. Applied Geochemistry. Vol. 33, pp. 346-356.

Detour Gold Corporation (DGC). (2016). Mineral Resource and Reserve Estimate for the Detour Lake Property. Retrieved from: <http://s22.q4cdn.com/327131108/files/doc downloads/2016-01-25Mineral-Resource-and-Reserve-Estimate-for-the-Detour-Lake-Property.pdf>

Detour Gold Corporation (DGC). (2017). Mineral Reserve and Resource Tables. Retrieved from: < https://www.detourgold.com/investors/news/press-releasedetails/2018/Detour-Gold-Reports-2017-Year-end-Mineral-Reserves-andResources/default.aspx>

Dubrovsky, N.M.. (1986). Geochemical evolution of inactive pyritic tailings in the Elliot Lake uranium district, Ph.D.Thesis, University of Waterloo, Waterloo, Ontario, Canada.

Fredlund, D., Rahardjo, H., \& Fredlund, M. D.. (2012). Unsaturated Soil Mechanics in Engineering Practice. Hoboken, New Jersey: John Wiley \& Sons, 2012.

Fredlund, D., \& Xing, A.. (1994). Equations for the soil-water characteristic curve. Canadian Geotechnical Journal, Vol. 31, pp. 521-532.

Fretz, Mackenzie Nathan. (2013). Multi-Year Hydrologic Response of Experimental Waste-Rock Piles in a Cold Climate: Active-Zone Development, Net Infiltration, and Fluid Flow. M.Sc. Project, University of British Columbia, Vancouver, British Columbia, Canada.

Gibson, Blair D., Amos, Richard T., Blowes, David W.. (2010). ${ }^{34} \mathrm{~S} /{ }^{32} \mathrm{~S}$ Fractionation during Sulfate Reduction in Groundwater Treatment Systems: Reactive Transport Modelling. Environmental Science \& Technology. Vol. 45, pp. 2863-2870.

Goldberg, E..(1954). Marine geochemistry I: Chemical scavengers of the sea. Journal of Geology. Vol. 62, pp. 249-265.

Gray, D. M., Toth, Brenda, Zhao, Litong, Pomeroy, W. J., Granger, R. J.. (2001). Estimating areal snowmelt infiltration into frozen soils. Hydrological Processes. Vol. 15, pp. 2095-3111.

Horowitz, Arthur, J.. (1985). A Primer on Trace-Metal-Sediment Chemistry. U.S. Geological Survey Water-Supply Paper 2277. Open-file report. Vol. 91, Issue 76.

Herasymuik, G. (1996). Hydrogeology of a sulfide waste rock dump. Doctoral dissertation, University of Saskatchewan, Saskatoon, Saskatchewan, Canada. Retrieved from:

<http://ecommons.usask.ca/handle/10388/etd-11132012-133516>

Hudson-Edwards, Karen A., Jamieson, Heather E., Lottermoser, Bernd G.. (2011). Mine Wastes: Past, Present, Future. Elements, Vol. 7, pp. 375-380.

The International Network for Acid Prevention (INAP). (2014). Global Acid Rock Drainage Guide (GARD Guide). Retrieved from:

< http://www.gardguide.com/index.php?title=Main Page > 
Jurjovec, Jasna, Blowes, David W., Ptacek, Carol J., Mayer, Ulrich K.. (2004). Multicomponent reactive transport modeling of acid neutralization reactions in mine tailings. Water Resources Research. Vol. 40, W11202, pp. 1-17.

Kjøller, Claus, Postma, Dieke, Larsen, Flemming. (2004). Groundwater Acidification and the Mobilization of Trace Metals in a Sandy Aquifer. Environment Science \& Technology. Vol. 38. Pp. 2828-2835.

Klein, C., Hurlbut, C.S, Dana, Dwight. (1993). Manual of Mineralogy, 21 ${ }^{\text {st }}$ Edition, Wiley, New York, 1993

Krauskopf, K..(1956). Factors controlling the concentration of thirteen rare metals in sea water. Geochimica et Cosmochimica Acta. Vol. 9, pp. 1-32.

La Brooy, S.R., Linge, Walker, G.s.. (1994). Review of gold extraction from ores. Minerals Engineering. Vol. 7, No. 10, pp. 1213-1241.

Landers, M., Usher, B., Faulkner D., Marianelli, P., Masterman, K..(2014). Field and Desktop Waste Rock Classification Guide for a Metalliferous Mine in the Northern Territory, Australia. Proceedings of the Eighth Australian Workshop on Acid and Metalliferous Drainage. pp.159-172. Retrieved from:

<http://www.klohn.com/wp-content/uploads/2015/05/Landers-et-al-Eighth-AMD-2014.pdf>

Langman, J.B., Moore, M.L., Ptacek, C.J., Smith, L., Sego, D., Blowes, D.W.. (2014). Diavik Waste Rock Project: evolution of mineral weathering, element release, and acid generation and neutralization during a 5-year humidity cell experiment. Minerals Vol. 4, Issue 2, pp.257-278.

Lichtner, P.C.. (1996). "Continuum formulation of multicomponent-multiphase reactive transport". In: Reactive Transport in Porous Media. Reviews in Mineralogy. Vol. 34, pp. 1-81.

Lenntech. (2018). Acids and Alkalis in Freshwater: Effects of changes in pH on freshwater ecosystems. Retrieved from: <http://www. Lenntech.com/aquatic/acids-alkalis.htm>

Levenspiel, O., (1972). Non-ideal flow. Chemical Reaction Engineering. Vol. 2, pp. 254-325.

Lottermoser, B.G.. (2010). Mine Wastes: Characterization, Treatment and Environmental Impacts, Third Edition, Springer, Berlin, Heidelberg. pp 400.

Mayer, Ulrich K., Xie, Mingliang, Su, Danyang, MacQuarrie, Kerry. (2015). MIN3P-THCm Theory Manual. University of British Columbia, Vancouver, B.C., and the University of New Brunswick, Fredericton, N.B., Canada.

Mayer, Ulrich K., Frind, Emil O., Blowes, David W.. (2002). Multicomponent reactive transport modeling in variably saturated porous media using a generalized formulation for kinetically controlled reactions. Water Resources Research. Vol. 38, No. 9, pp. 1174. doi:10.1029/2001WR000862.

Mayer, K. U., Benner, S. G., Frind, E. O.. (1999). The reactive transport model MIN3P: Application to acid 
mine drainage generation and treatment - Nickel Rim Mine Site, Sudbury, Ontario. Conference paper presented at Mining and the Environment II Conference, Cent. in Mining and Mining Environ. Res., Laurentian Univ., Sudbury, Ontario, Canada.

McNeill, Brayden. (2016). Geochemical and Microbiological Characterization of the Historic Waste Rock Piles at the Detour Lake Gold Mine. M.Sc. Project, University of Waterloo, Waterloo, Ontario, Canada.

Molson, J., Aubertine, M., Bussière, B., Benzaazoua, M.. (2008). Geochemical transport modelling of drainage from experimental mine tailings cells covered by capillary barriers. Applied Geochemistry. Vol. 23, pp. 1-24.

Momeyer, Alexander Steven. (2014). Hydrologic Processes in Unsaturated Waste Rock Piles in the Canadian Subarctic. M.Sc. Project, University of British Columbia, Vancouver, British Columbia, Canada.

Moncur, M.C., Ptacek, C.J., Blowes, D.W., Jambor, J.L. (2005). Release, transport and attenuation of metals from an old tailings impoundment. Applied Geochemistry. Vol. 20, pp. 639-659.

Monteith, J. L. (1965). "Evaporation and Environment." In: The state and movement of water in living organism. $19^{\text {th }}$ Symposia Society for Experimental Biology. pp. 205-234.

Morin, K.A. (1983). Prediction of subsurface contaminant transport in acidic seepage from uranium tailings impoundments. Ph.D. Thesis, University of Waterloo, Waterloo, Ontario, Canada.

Morin, K.A., Cherry, J.A., Dave, N.K., Lim, T.P., Vivyurka, A.J.. (1988). Migration of acidic groundwater seepage from uranium-tailings impoundments. 1. Field study and conceptual hydrogeochemical model. Journal of Contaminant Hydrology. Vol. 2, pp. 271-303.

Muskett, R., Reginald. (2012). Remote Sensing, Model-Derived and Ground Measurements of Snow Water Equivalent and Snow Density in Alaska. International Journal of Geosciences. Vol. 3, pp 1127-1136.

National Orphaned and Abandoned Mines Initiative (2018). NOAMI mines Inventory. Retrieved from: < http://www.abandoned-mines.org/en/noami-inventory/>

Neuner, Matthew, Smith, Leslie, Blowes, W. David, Sego, C. David, Smith, J.D. Lianna, Fretz, Nathan, Gupton, Michael. (2012). The Diavik waste rock project: Water flow through mine waste rock in a permafrost terrain. Applied Geochemistry. Vol. 36, pp. 222-233.

Nichol, Craig, Smith, Leslie, Beckie, Roger. (2005). Field-scale experiments of unsaturated flow and solute transport in a heterogeneous porous medium. Water Resources Research, Vol. 41, W05018, doi:10.1029/2004WR003035.

Nicholson, Ronald V., Scharer, Jeno M.. (1994). Laboratory Studies of Pyrrhotite Oxidation Kinetics. Environmental Geochemistry of Sulfide Oxidation. pp. 14-30.

Noël, Michael M., Ritchie, A. Ian M.. (1999). Some Physical Properties of Water Transport in Waste Rock 
Material. Mine, Water \& Environment. IMWA Congress. Sevilla, Spain, 1999.

Nordstrom, D. Kirk, Alpers, C.N. (1999). “Geochemistry of Acid Mine Waters”. In: Plumlee, G.S., Logsdon, M.J.. The Environmental Geochemistry of Mineral Deposits. Reviews in Economic Geology. Vol. 6A, pp. 133-160.

Oliver, J., Ayer, J., Dube, B., Aubertin, R., Burson, M., Panneton, G., Friedman, R., Hamilton, M., (2012). Structure, stratigraphy, U-Pb geochronology and alteration characteristics of gold mineralization at the Detour Lake gold deposit, Ontario, Canada. Exploration and Mining Geology. Vol. 20, pp. $1-30$.

Ontario Ministry of Northern Development and Mines (2018). Abandoned Mines database. Retrieved from: <https://www.mndm.gov.on.ca/en/mines-andminerals/applications/ogsearth/abandoned-mines $>$

Ouangrawa, M., Molson, J., Aubertine, M., Bussière, B., Zagury, G. J.. (2009). Reactive transport modelling of mine tailings columns with capillarity-induced high water saturation for preventing sulfide oxidation. Applied Geochemistry. Vol. 24, pp. 1312-1323.

Pabst, Thomas, Molson, John, Aubertin, Michel, Bussière, Bruno. (2017). Reactive transport modelling of the hydro-geochemical behaviour of partially oxidized acid-generating mine tailings with a monolayer cover. Applied Geochemistry. Vol. 78, pp. 219-233.

Panday, Sorab, Huyakorn, Peter S., Therrien, R., Nichols, R. L.. (1993). Improved three-dimensional finite-element techniques for field simulation of variably saturated flow and transport. Journal of Contaminant Hydrology. Vol. 12, Issue 1-2, pp. 3-33.

Penman, H. L. (1948). Natural evaporation from open water, bare soil and grass. Proceedings of the Royal Society of London. Series A, Mathematical and Physical Sciences. Vol. 193, No. 1032, pp. 120-145.

Pomeroy, J.W., Jones, H.G.. (1996). Wind-blown Snow: Sublimation, Transport and Changes to Pola Snow. Chemical Exchange between the Atmosphere and Polar Snow. pp 453-490, NATO ASI

Richards, L.A. (1931). Capillary conduction of liquids in porous mediums. Journal of Applied Physics. Vol. 1, pp. 318-333.

Robertson, J., Barazzuol, L., \& Day, S. (2012). Extraction of ARD/ML Information from a Brownfield Site for Development of an ARD/ML Plan at the Detour Gold Mine, Ontario, Canada. Paper presented at $9^{\text {th }}$ International Conference on Acid Rock Drainage (ICARD), Ottawa, Ontario, 20-26 May. Ottawa, Ontario: Mine Environment Neutral Drainage (MEND).

Robin, M.J.L. (2011). Course notes for GEO 3342 Introduction to Hydrogeology, University of Ottawa, Ottawa, Ontario, Canada.

Rutherford, G. K.. (1967). A Preliminary Study of the Composition of the Precipitation in S.E. Ontario. Canadian Journal of Earth Sciences. Vol 4, pp. 1151-1160. 
Simate, G.S., Ndlovu, S.. (2014). Acid mine drainage: Challenges and opportunities. Journal of Environmental Chemical Engineering. Vol. 2, pp. 1785-1803.

Singh, R., Gautam, N., Mishra, A., Gupta, R.. (2011). Heavy metals and living systems: an overview. Indian J. Pharmacol. Vol. 43, No. 3, pp. 246-253.

Singh, Shailendra K., Subramanian, V., Gibbs, Ronald J.. (1984). Hydrous FE and MN oxides scavengers of heavy metals in the aquatic environment. Critical Reviews in Environmental Control. Vol. 14, Issue 1. pp. 33-90. DOI: 10.1080/10643388409381713

Smyth, D.J.A. (1981). Hydrogeological and geochemical studies above the water table in an inactive uranium tailings impoundment near Elliot Lake, Ontario. M.Sc. Project, University of Waterloo, Waterloo, Ontario, Canada.

Solomon F.. (2008). Impacts of Metals on Aquatic Ecosystems and Human Health. Retrieved from: <http://www.infomine.com/library/publications/docs/Min- ing.com/Apr2008c.pdf >

Statistics Canada. (2012). "Canada's waste generation: the big picture”. Retrieved from: <https://www.statcan.gc.ca/pub/16-201-x/2012000/part-partie2-eng.htm>

Steefel, C.I., Lasaga, A.C.. (1994). A coupled model for transport of multiple chemical species and kinetic precipitation/dissolution reactions with application to reactive flow in single phase hydrothermal systems. American Journal of Science. Vol. 294, pp. 529-592.

Steinepreis, Mark. (2017). Investigation of Gas Transport Rates Through a Covered Waste Rock Pile and Synchrotron Studies on the Sulfide Oxidation Reaction. M.Sc. Project, University of Waterloo, Waterloo, Ontario, Canada.

Stockwell, Justin, Smith, Leslie, Jambor L., John, Beckie, Roger. (2006). The relationship between fluid flow and mineral weathering in heterogeneous unsaturated porous media: A physical and geochemical characterization of a waste-rock pile. Applied Geochemistry, Vol. 21, pp. 12471261.

Strömberg, Bo, Banwart, Steven. (1999). Weathering kinetics of waste rock from the Aitik copper mine, Sweden: scale dependent rate factors and $\mathrm{pH}$ controls in large column experiments. Journal of Contaminant Hydrology. Vol. 39, pp. 59-89.

Sturm, Matthew, Taras, Brian, Liston, E., Glen, Derksen, Chris, Jonas, Tobias, Lea, Jon. (2010). Estimating Snow Water Equivalent Using Snow Depth Data and Climate Classes. Journal of Hydrometeorology, Vol. 11, pp. 1380-1394.

Szramek, Kathryn, McIntosh, Jennifer C., Williams, Erika L., Kanduc, Tjasa, Ogrinc, Nives, Walter, Lynn M.. (2007). Relative weathering intensity of calcite versus dolomite in carbonate-bearing temperate zone watersheds: Carbonate geochemistry and fluxes from catchments within the St. Lawrence and Danube river basins. Geochemistry Geophysics Geosystems. Vol. 8, Issue 4. pp. 1525-2027. 
The Mining Association of Canada. (2016). "2016 facts and figures". Retrieved from: $<$ http://mining.ca/sites/default/files/documents/Facts-and-Figures-2016.pdf >

Thorstenson, D.C., Pollock, D.W.. (1989). Gas transport in unsaturated porous media: The adequacy of Fick's law. Reviews of Geophysics. Vol. 27, pp. 61-78.

Tremblay GA, Hogan CM (eds) .(2001). Mine Environment Neutral Drainage (MEND) Manual 5.4.2d: Prevention and Control. Canada Centre for Mineral and Energy Technology, Natural Resources Canada, Ottawa. pp. 352.

Van Genuchten. (1980). A closed-form equation for predicting the hydraulic conductivity of unsaturated soils. M.Sc. Project. Soil Science Society of America. Vol. 44, pp. 892-898.

Wilson, David, Amos, Richard T., Blowes, David W., Langman, Jeff B., Ptacek, Carol J., Smith, Leslie, Sego, David C.. (2018). Diavik Waste Rock Project: A conceptual model for temperature and sulfide content dependent geochemical evolution of waste rock - Laboratory scale. Applied Geochemistry. Vol. 89, pp. 160-172.

Wösten, J. H. M., van Genuchten, M. T.. (1988). Using texture and other soil properties to predict the unsaturated soil hydraulic functions. Soil Science Society of America. Vol. 52, pp. 1762-1770.

Wunderly, M,D., Blowes, D.W., Frind, E.O., Ptacek, C.J., (1996). Sulfide mineral oxidation and subsequent reactive transport of oxidation products in mine tailings impoundments: A numerical model. Water Resources Research. Vol. 32, No. 10, pp. 3173-3187.

Yagi, S., Kunii, D.. (1955). Studies on combustion of carbon particles in flames and fluidized beds. In: Fifth Symposium (International) on Combustion, Reinhold, New York. Pp. 231-244.

Yeh, G.T., Tripathi, V.S.. (1989). A critical evaluation of recent developments in hydrogeochemical transport models of reactive multichemical components. Water Resource Research. Vol. 25, pp. 93-108. 


\section{Appendix A}

Corrections for Evapotranspiration, Snow Water Equivalent and

Sublimation 


\section{Evapotranspiration Correction}

Infiltration through a soil is a function of precipitation, evapotranspiration and soil properties. Many of the empirical methods used to estimate evapotranspiration were derived from the Penman equation (Penman, 1948):

$\lambda E=\frac{\left[\Delta\left(R_{n}-G\right)\right]+\left(\gamma \lambda E_{a}\right)}{(\Delta+\lambda)}$

where $\lambda E$ is evaporative latent heat flux $\left(\mathrm{MJ} \mathrm{m}^{-2} \mathrm{~d}^{-1}\right), \Delta$ is the slope of the saturated vapor pressure curve, $R_{n}$ is the net radiation flux ( $\left.\mathrm{MJ} \mathrm{m} \mathrm{m}^{-2} \mathrm{~d}^{-1}\right), G$ is the sensible heat flux into soil $\left(\mathrm{MJ} \mathrm{m}^{-2} \mathrm{~d}^{-1}\right) \gamma$ is the psychrometric constant $\left(\mathrm{kPa}^{\circ} \mathrm{C}^{-1}\right)$ and $E_{a}$ is the vapor transport of flux $\left(\mathrm{mm} \mathrm{d}^{-1}\right)$. To account for daily variations, Monteith (1965) combined the Penman equation with a bulk surface resistance term of vapor flow through a transpiring crop or evaporating soil, $r_{a v}\left(\mathrm{~s} \mathrm{~m}^{-1}\right)$. The result is the Penman-Monteith equation, written as:

$\lambda E T_{o}=\frac{\Delta\left(R_{n}-G\right)+\left[86,400 \frac{\rho_{a} C_{p}\left(e_{s}^{o}-e_{a}\right)}{r_{a v}}\right]}{\Delta+\gamma\left(1+\frac{r_{s}}{r_{a v}}\right)}$

Where $\rho_{a}$ is the air density $\left(\mathrm{kg} \mathrm{m}^{-3}\right), C_{p}$ is the specific heat of dry air, $e_{s}^{0}$ is the mean saturated vapor pressure ( $\mathrm{kPa}), e_{a}$ is the mean daily ambient vapor pressure $(\mathrm{kPa})$ and $r_{s}$ is the canopy surface resistance $\left(\mathrm{s} \mathrm{m}^{-1}\right)$. Finally, an updated version suggested by Allen et al. (1998), known as the Penman-Monteith (FAO-56) method, utilizes some assumed constants simplifying the equation to:

$E T_{0}=\frac{0.408 \Delta\left(R_{n}-G\right)+\gamma \frac{900}{T_{\text {mean }}+273} u_{2}\left(e_{s}-e_{a}\right)}{\Delta+\gamma\left(1+0.34 u_{2}\right)}$

Where $E T_{o}$ is the reference evapotranspiration rate $(\mathrm{mm} /$ day $), T$ is the mean air temperature $\left({ }^{\circ} \mathrm{C}\right)$ and $u_{2}$ is the wind speed $(\mathrm{m} / \mathrm{s})$ measured at $2 \mathrm{~m}$ above the ground. This equation can be reduced to two components $E T_{\text {wind }}$ and $E T_{\text {rad }}$ :

$E T_{o}=E T_{\text {wind }}+E T_{\text {rad }}$ 
The $E T_{\text {wind }}(\mathrm{mm} /$ day) component is made up of three terms; a temperature term, a wind term, and a calculation for vapour pressure. The temperature term $T T$ can be written as:

$T T=\left[\frac{900}{T_{\text {mean }}+273}\right] \cdot u_{2}$

The wind term $P T$ is written as:

$$
P T=\frac{\gamma}{\Delta+\gamma\left(1+0.34 u_{2}\right)}
$$

The vapour pressure calculation is simply $\left(e_{s}-e_{a}\right)$ where $e_{a}$ is actual vapour pressure $(\mathrm{kPa})$, and $e_{s}$ is mean saturation vapour pressure $(\mathrm{kPa})$, calculated based on the air temperature. Therefore, $E T_{\text {wind }}$ is:

$$
E T_{\text {wind }}=P T \cdot T T\left(e_{s}-e_{a}\right)
$$

The final component $E T_{\text {rad }}(\mathrm{mm} /$ day) is the radiation component, made up of two terms, $D T$ (delta term), and the net radiation $R_{n g}(\mathrm{~mm})$. The delta term is:

$$
D T=\frac{\Delta}{\Delta+\gamma\left(1+0.34 u_{2}\right)}
$$

The net radiation is:

$R_{n g}=0.408 \cdot R_{n}$

And so, the $E T_{\text {rad }}$ is:

$$
E T_{r a d}=D T \cdot R_{n g}
$$

Where $R_{n}$ is net radiation (M Jm-2 day-1) and is the difference between net shortwave radiation and net outgoing longwave radiation. Net daily infiltration / can then be solved by subtracting the evapotranspiration $E T_{o}$ from total precipitation:

$I=\operatorname{Rain}_{\operatorname{daily}(m m)}-E T_{0}$

\section{Snow Water Equivalent (SWE) and Sublimation Correction}

In the spring, an influx of water due to a melting snowpack is not accurately represented by precipitation data. To account for this influx during the month of April, a modified Snow Water 
Equivalent (SWE) calculation was used. The standard SWE is dependent on the density of the snow and the snow depth and is calculated as (Sturm et al., 2010):

$$
m m S W E=\operatorname{SnowDepth}(\mathrm{mm}) \cdot \operatorname{Density}\left(\mathrm{kg} \cdot \mathrm{m}^{3}\right) / 1000
$$

The snow type during the spring melt in April is estimated to be very wet due to high rates of melt with a density of $700 \mathrm{~kg} / \mathrm{m}^{3}$ (Muskett, 2012). Pomeroy and Jones (1996) provides an equation to estimate snowpack loss due to sublimation:

$$
S W E_{s u b}=7.206+(1.764 \cdot U)-\left(0.158 \cdot T_{\max }\right)-\left(0.176 \cdot R H_{\max }\right)+\left(0.191 \cdot P_{m}\right)
$$

Where $U$ is the mean monthly wind speed (in $\mathrm{m} / \mathrm{s}$ ), $T_{\max }$ is the mean monthly air temperature (in ${ }^{\circ} \mathrm{C}$ ), $R H_{\text {max }}$ is the mean monthly max relative humidity (\%) and $P_{m}$ is the monthly snowfall (mm SWE). The mm SWE infiltration into the soil is dependent on the soil type and porosity (Gray et al., 2001). The soil types are divided into three categories; Unlimited, Restricted and Limited soils. Unlimited soils are dominated by gravity flow and allow most if not all meltwater to infiltrate. Restricted soils have an impervious layer near the ground surface, a common example being frozen soils or an ice lens below the subsurface impeding infiltration. The third category is Limited soils, and they are described as soil where infiltration is dominated by capillary flow dependent on soil moisture content, temperature, and length of time in which infiltration occurs. Since capillary flow is the primary flow mechanism through the waste rock and cover material at Detour Gold, the soil type can be assumed to be a Limited soil type. Net infiltration can then be estimated using the mm SWE curves from Gray et al. (2001) and porosity estimates gathered from field observations. 


\title{
Appendix B
}

\author{
Additional Figures
}




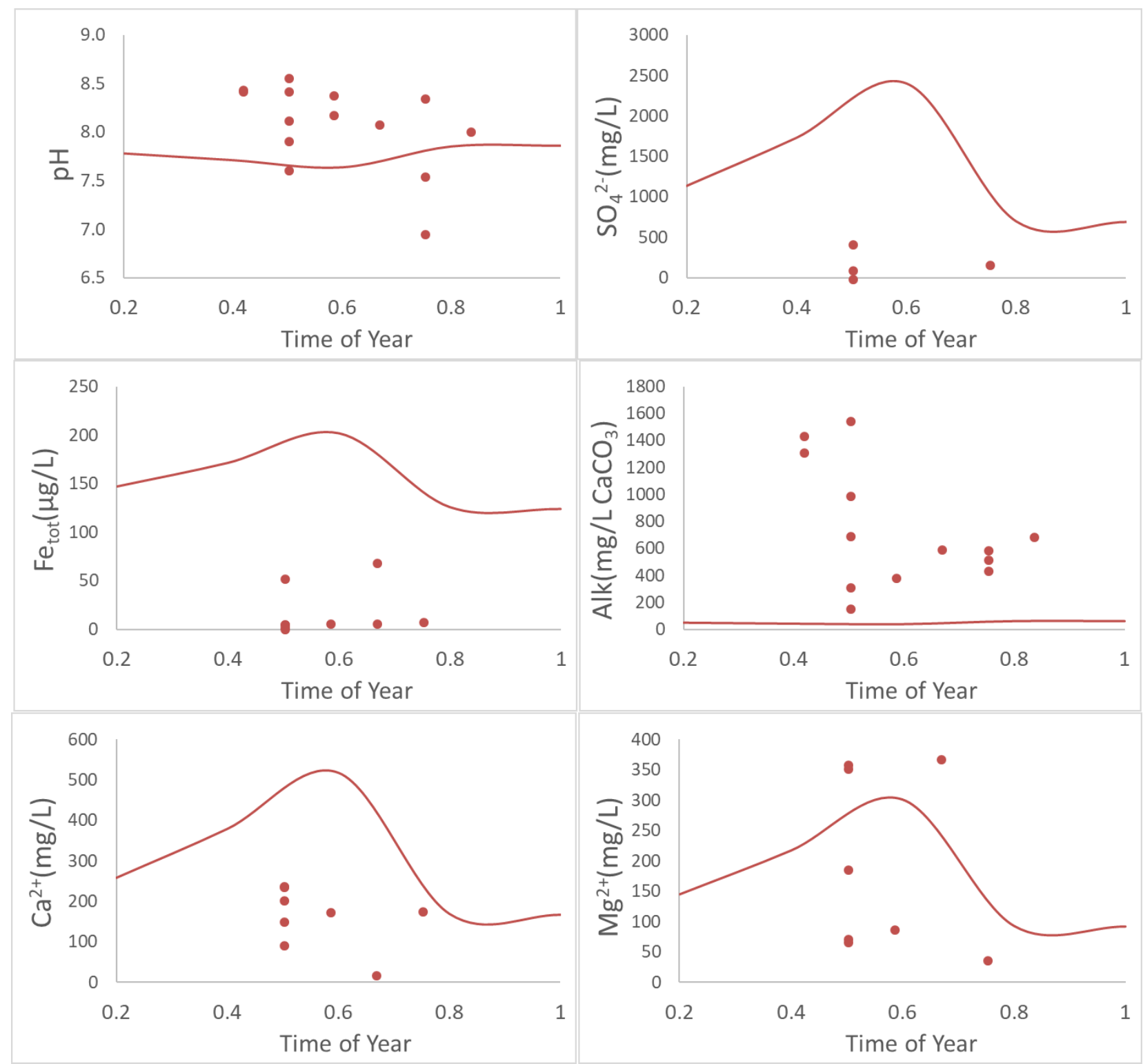

FIGURE 26 - SIMULATED WATER GEOCHEMISTRY VARIANCE AT $10 \mathrm{M}$ FOR THE $29^{\text {TH }}$ YEAR, PLOTTED WITH PORE WATER GEOCHEMISTRY COLLECTED AT 5 M DEPTH. 

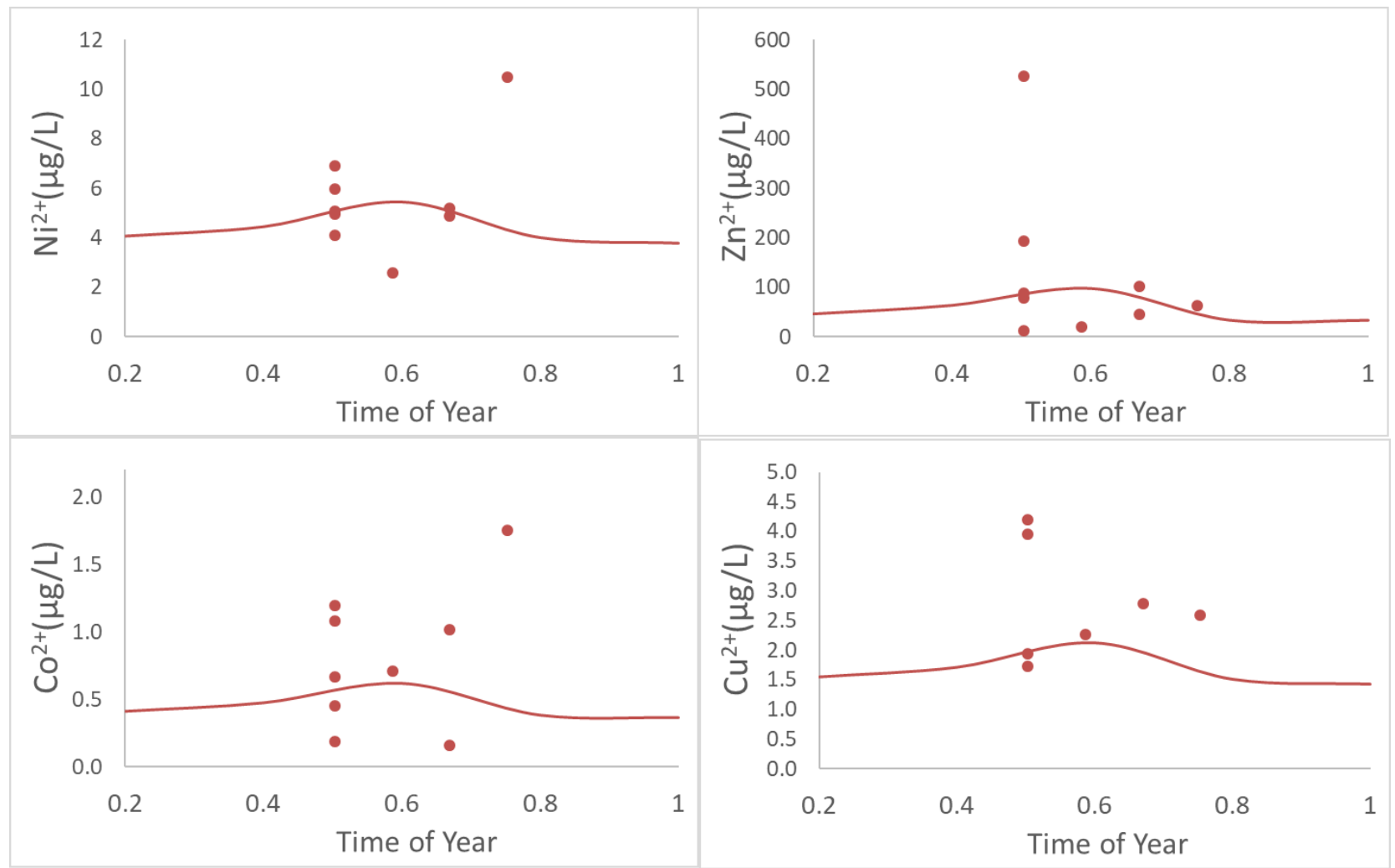

FIGURE 27 - SiMULATED WATER GEOCHEMISTRY VARIANCE AT $10 \mathrm{M}$ FOR THE $29^{\text {TH }}$ YEAR, PLOTTED WITH TRACE METAL DATA COLLECTED AT $5 \mathrm{M}$ DEPTH. 


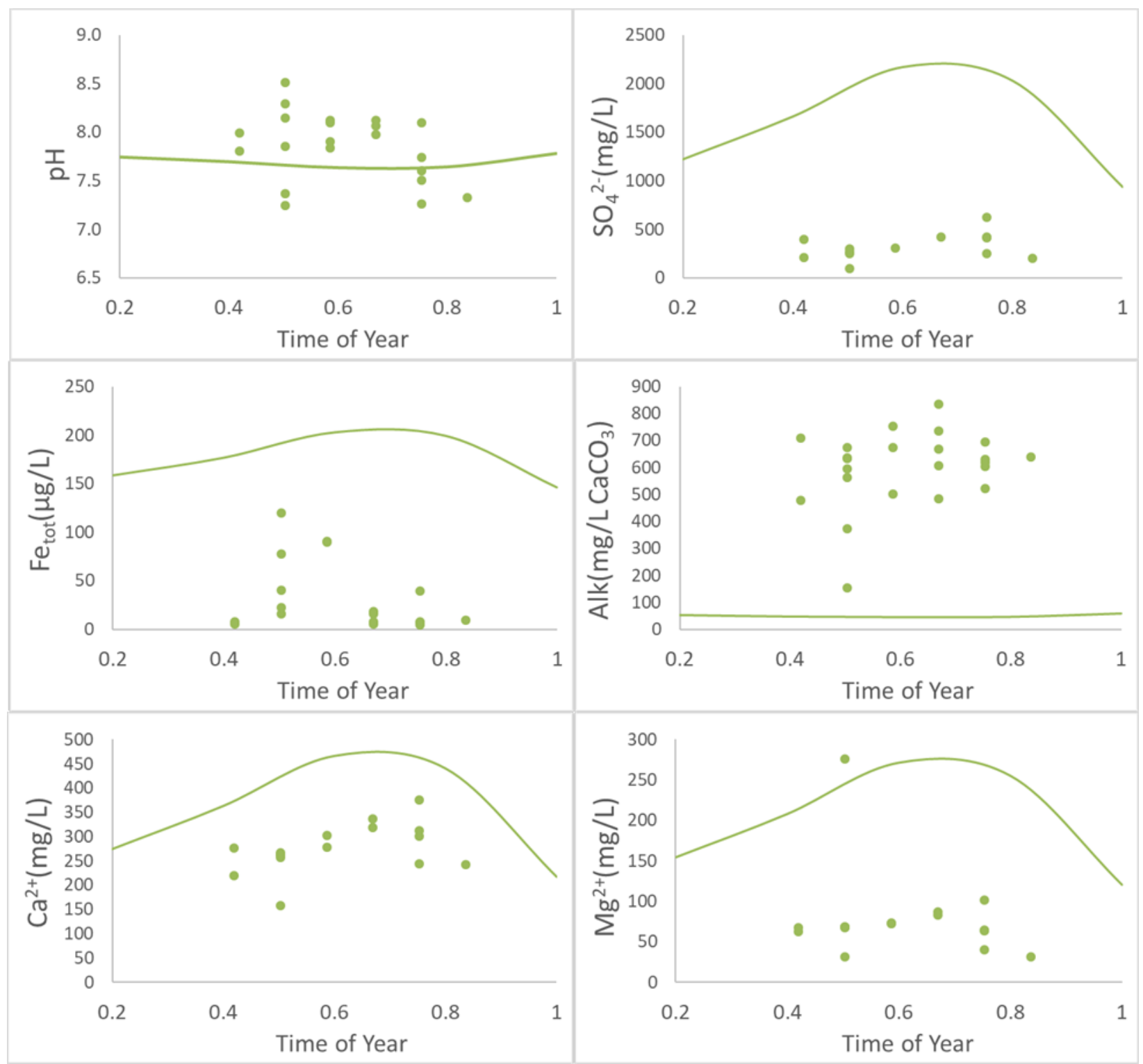

FIGURE 28 - SIMULATED WATER GEOCHEMISTRY VARIANCE AT 15 M FOR THE $29^{\text {TH }}$ YEAR, PLOTTED WITH PORE WATER GEOCHEMISTRY COLLECTED AT 5 M DEPTH. 

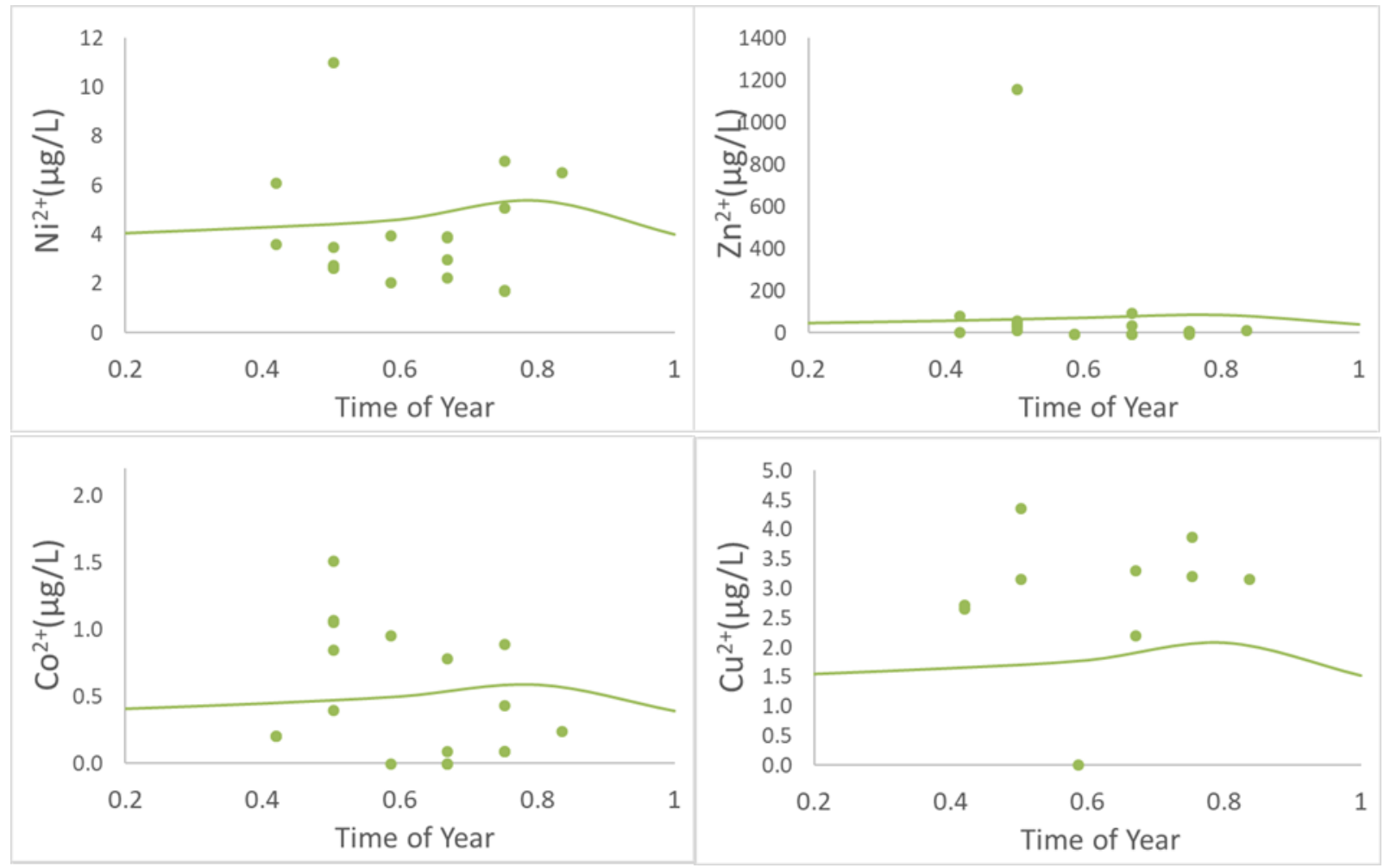

FIGURE 29 - SiMULATED WATER GEOCHEMISTRY VARIANCE AT 15 M FOR THE $29^{\text {TH }}$ YEAR, PLOTTED WITH TRACE METAL DATA COLLECTED AT 5 M DEPTH. 